DePartment OF THE INTERIOR Hubert Work, Secretary

U. S. GEOLOGICAL BURVEX George Otis Smith, Director

Professional Paper 143

\title{
PALEONTOLOGY AND STRATIGRAPHY OF THE CASTLE HAYNE AND TRENT MARLS IN NORTH CAROLINA
}

BY

LEWIS BURNETT KELLUM

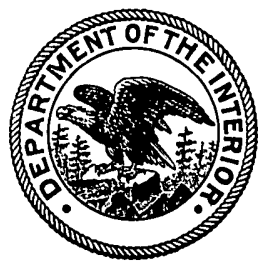

WASHINGTON

GOVERNMENT PRINTING OFEICE

1928 
ADDITIONAL COPIES

OF THIS PUBLICATION MAY BE PROCURED FROM THE SUPERINTENDENT OP DOCUMENTS

GOVERNMENT PRINTINO OFFICE

WASHINGTON, D. C.

30 CENTS PER COPY 


\section{CONTENTS}

Introduction

Acknowledgments

Historical review . . . . . .

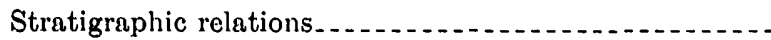

Analysis of the Castle Hayne fauna..................

General considerations . . .

Biologic analysis...........

Correlation . . . . . . . . .

Field stations of the Castle Hayne marl . . . . . . . .

Analysis of the Trent fauna...........................

Field stations of the Trent marl ....................

Systematic paleontology of the Castle Hayne marl ....

Echinodermata . . . . . . . . . . . . .

Cidaridae.

Fibularidae. . .

Scutellidae. . . . .

Cassidulidøe. . . . . . . . . . .

Spatangidae...............................

Pelecypoda.............

Arcidae.

Ostreidae

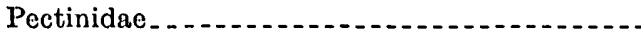

Spondylidre.......

Anomiidae. .........

Pholadomyidae. . . . . . . . . .

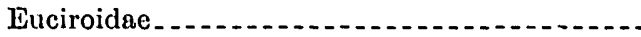

Crassatellitidae.............................

Carditidae. . . . . . . . . . . .

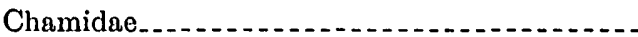

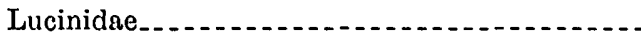

Isocardiidae........

Veneridae . . . . .

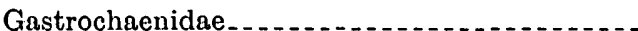

Gastropoda

Pleurotomariidae.

Fissurellidae.

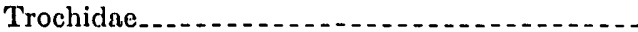

Epitoniidae

Calyptraeidae.

\begin{tabular}{|c|c|c|}
\hline age & & Page \\
\hline 1 & Systematic paleontology of the Castle Hayne marl-Cc & \\
\hline 1 & Gastropoda-Continued. & \\
\hline 1 & Xenophoroidae & 27 \\
\hline 4 & Turritellidae. & 27 \\
\hline 6 & Vermiculariidae & 27 \\
\hline 6 & Strombidae. & 27 \\
\hline 6 & Cypraeidae. & 28 \\
\hline 8 & Cassididae & 28 \\
\hline 9 & Buccinidae & 29 \\
\hline 12 & Fasciolariidae & 29 \\
\hline 13 & Turbinellidae. & 30 \\
\hline 14 & Marginellidae & 30 \\
\hline 14 & Volutidae. & 30 \\
\hline 14 & Conidae. & 31 \\
\hline 14 & Cephalopoda & 32 \\
\hline 15 & oda $\ldots$ & 33 \\
\hline 15 & Rhynchonellidae & 33 \\
\hline 15 & Terebratulidae & 33 \\
\hline 16 & Systematic paleontology of the Trent marl & 34 \\
\hline 16 & Pelecypoda & 34 \\
\hline 17 & Arcidae & 34 \\
\hline 19 & Pectinidae & 35 \\
\hline 21 & lidae & 36 \\
\hline 21 & Astartidae & 36 \\
\hline 22 & llitidae & 36 \\
\hline 22 & $\begin{array}{l}u^{\prime} \\
\end{array}$ & 36 \\
\hline 22 & Lucinidae & 37 \\
\hline 23 & Cardiidae & 37 \\
\hline 23 & Veneridae. & 37 \\
\hline 23 & Saxicavidae & 39 \\
\hline 24 & Gastropoda & 39 \\
\hline 24 & Capulidae...... & 39 \\
\hline 24 & Naticidae $\ldots \ldots$ & 40 \\
\hline 24 & Turritellidae $\ldots$ & 40 \\
\hline 24 & Buccinidae. & 40 \\
\hline 25 & Volutidae. & 40 \\
\hline 26 & Olividae $_{2}$ & 41. \\
\hline 26 & Conidae & 41 \\
\hline 27 & $\cdots$ & 55 \\
\hline
\end{tabular}

\section{ILLUSTRATIONS}

Plates I-XI. Fossils from the Castle Hayne and Trent marls .

FIGURe 1. Index map showing field stations in the Castle Hayne and Trent marls 


\title{
PALEONTOLOGY AND STRATIGRAPHY OF THE GASTLE HAYNE AND TRENT MARLS IN NORTH CAROLINA
}

\author{
By Lewis Burnett Kellum
}

\begin{abstract}
INTRODUCTION
The present work was undertaken for the purpose of clearing up certain doubtful relations in the Tertiary section of North Carolina. The problem has been approached through a systematic study of the faunas, supplemented by a consideration of the lithology of the formations involved. Fossils have been collected at many localities, and through their study a material revision of the areal geology and stratigraphic succession has been possible.

Two or three well-known fossil localities in the Castle Hayne marl have been repeatedly visited by collectors, who from time to time have described organic remains from this horizon. The numerous collections that have accumulated in the United States National Museum furnished the basis for the present paleontologic study. A number of new species are described in this report, and the descriptions of earlier workers are brought together. The old species of which a more critical delineation was necessary are redescribed.

The fauna of the Trent marl has not been studied heretofore, probably because of the very poor state of preservation in which the fossils are usually found. The Trent was established primarily because of its lithologic character. It consists chiefly of lightcolored calcareous marl either loose or locally consolidated into hard compact limestone. During the field investigation for the present report the writer was exceptionally fortunate in getting a collection of perfectly preserved shells from a marl deposit in the Trent formation. The study of this fauna has thrown new light on the age of the Trent and has revealed the northward extension of lower Miocene deposits previously recognized on the east coast only in Florida and Georgia.
\end{abstract}

\section{ACKNOWLEDGMENTS}

It is with the greatest pleasure that the writer takes this opportunity to express publicly his indebtedness to a few of the many who have made this work possible.

The study was undertaken at the suggestion of C. Wythe Cooke, of the United States Geological
Survey, and the results obtained are in large measure due to his continued interest and friendly criticism. He generously permitted the writer to use his desk and equipment at the United States National Museum and gave his personal attention to every detail which might facilitate the investigation. The field work was done under the auspices of the Geological Survey's section of Coastal Plain investigations.

The writer is indebted to Prof. E. W. Berry, of Johns Hopkins University, under whose supervision the work has been carried on. His enthusiasm for research has been a constant source of inspiration and encouragement, and his sound judgment on paleontologic problems and principles of sedimentation have been of invaluable assistance in interpreting the stratigraphy of North Carolina.

To Miss Julia Gardner, of the United States Geological Survey, the writer desires to express his sincere appreciation for many suggestions contributed during the study of the faunas. The results of her extended researches on the Mollusca of the Coastal Plain have been generously placed at his disposal.

Recognition is made with great appreciation of the help rendered by Messrs. L. W. Stephenson, W. P. Woodring, and W. C. Mansfield, of the United States Geological Survey, who during the comparative study of the faunas in the National Museum gave freely of their time and experience in assisting the writer.

Fossils from the Castle Hayne and Trent marls have been deposited in the United States National Museum by E. W. Berry, T. W. Stanton, L. W. Stephenson, T. W. Vaughan, C. W. Cooke, J. A. Cushman, B. L. Miller, and Frank Burns. It is through the use of these collections that the rather extensive paleontologic study has been possible. Mr. John Gillette, of Silverdale, Onslow County, N. C., on whose farm the well-preserved Trent fossils were found, very kindly sent the writer an additional collection from that horizon.

\section{HISTORICAL REVIEW}

The study of the early Tertiary deposits of North Carolina prior to 1912 was of a very general nature. Numerous writers during the last century have re- 
ferred briefly to these deposits, and in scattered papers have described fossils and fossil localities with varying opinions regarding their age and correlation. The earliest writers included all the deposits of the Coastal Plain in one unit, which they called the "Alluvial Formation," "the Sandy Region," or "the low country." 3

Elisha Mitchell in 1828 observed that the "low country" of North Carolina was made of bedded deposits, and suggested that more extended and careful examination might reduce them to order and regularity. He thought, however, that the deposits represented a single horizon and in this regard says: "The shells are everywhere of the same age. They belong to the same genera and species, with such variations only as are common in the living animals in the neighboring bays and harbors, and in many cases to the genera and species now inhabiting the Atlantic coast."

In 1841 James T. Hodge, discussing the "Secondary" and Tertiary formations of the Southeastern Atlantic States, described an outcrop of limestone in the western part of Jones County, N. C., and mentioned the sandstone and conglomerate underlying the Miocene at Wilmington. He erroneously referred these beds to the "Secondary Formation"- that is, the Cretaceous.*

Charles Lyell in 1845 was the first to recognize the presence of Eocene deposits in North Carolina. He visited the section at Wilmington, New Hanover County, and "collected fossils from Tertiary formations of two ages - the Miocene marls and an underlying Eocene limestone." 5

Ebenezer Emmons's first report on the geology of North Carolina (1852) describes the lithologic character of the Eocene deposits and rather hazily sketches their areal extent. He suggests that the Eocene might be subdivided into two or more formations and says: ${ }^{6}$

It is difficult to subdivide the formation slearly, though it appears that it admits of the same division as in Alabama and Mississippi-the cherty portion beneath and the consolidated marl or marlstone above. But this part furnishes very few fossils. There is still a mass, quite sandy, similar in outward appearance to the greensand, which forms a feature which should not be overlooked in making the natural division of the strata.

It is not clear what Emmons had in mind by his several lithologic terms, and it was not until 1912 that such a division of the Eocene was attempted.

In the second report of the North Carolina Geological Survey, Emmons gave a more definite state-

\footnotetext{
1 Maclure, William, Am. Philos. Soc. Trans., vol. 6, pp. 411-423, 1809; new ser., vol. 1, pp. 1-91, 1818.

2 Dickson, John, Am. Jour. Sci., vol. 3, pp. 1-4, 1821.

1 Mitchell, Elisha, Geology of North Carolina, pt. 3, pp. 1-27, 1827; Am. Jour. Sci., vol. 13 , pp. $336-346,1828$.

- Hodge, J. T., Assoc. Am. Geologists and Naturalists Trans., 1841, pp. 97, 100.

s Lyell, Charles, Travels in North America, vol. 1, p. 156, 1845.

- Enımons, Ebenezer, Report of Professor Emmons on his geological survey of

North Carolina, pp. 102-107, 1852.
}

ment of the extent of the Eocene deposits. ${ }^{7}$ The area outlined at that time is essentially the same in all subsequent reports.

The Eocene marl occupies a narrow but an ill-defined zone stretching across several of the eastern counties, from the lower waters of the Cape Fear, in Hanover County, through a part of Onslow, Jones, and Craven counties, crossing the Neuse 20 miles above New Bern. *** The Eocene is known to exist at Wilmington, at Polloksville, in Jones County, and underlies the whole county in the vicinity of New Bern, upon the Neuse. In this formation I include the consolidated beds, which have been employed for millstones and which consist of a mass of the casts of shells, the most common of which is a small species of clam.

These consolidated beds that crop out along Trent and lower Neuse rivers are the typical Trent marl, which Miller in 1912 separated as the basal division of the Eocene.

W. C. Kerr in 1875 again outlined the areal distribution of the Eocene beds, mentioned numerous localities on Neuse, Trent, New, and Northeast Cape Fear rivers, and briefly described the lithologic character of the outcrops. He also recognized the presence of Eocene outliers in Wake and Moore counties capping the hills at an altitude of about 350 feet. ${ }^{8}$ Later, in 1885 , because of these outliers at such a height above sea level, he erroneously concluded that most of the sand and gravel previously referred to the Quaternary are really Eocene. He then considered "the Quaternary, like the Miocene, to be represented by a thin and broken covering of superficial deposits."

The occurrence of Cretaceous and Eocene fossils apparently in the same bed at Wilmington has been the subject of much discussion by paleontologists. Tuomey ${ }^{10}$ in 1848 stated that "well-characterized Cretaceous forms" occur at Wilmington in the same beds with fossils that are "considered characteristic of the Eocene of the United States." In a later publication ${ }^{11}$ he explained this mixture on the ground of contemporaneous existence. Conrad ${ }^{12}$ in 1865 observed, concerning this locality, that "Eocene and Cretaceous fossils are there mingled in a breccia," which indicates "that a disturbance occurred in the bed of the Eocene ocean." William Bullock Clark, ${ }^{13}$ in discussing the Tertiary deposits of the Cape Fear River region, gave lists of the Cretaceous and Eocene forms occurring at Wilmington and explained their mixture as due to a "mechanical commingling of the various forms $* * *$ during the deposition of Eocene sediments." The following year T. W.

7 Emmons, Ebenezer, Report of the North Carolina Geological Survey, Agriculture of the eastern counties, Raleigh, 1858, pp. 101-102.

${ }^{8}$ Kerr, W. C., Report of the geological survey of North Carolina, vol. 1, pp. $149-150,1875$.

${ }^{9}$ Kerr, W. C., Am. Naturalist, vol. 19, p. 69, 1885.

10 Tuomey, Michael, Am. Assoc. Adv. Sci. Proc., vol. 1, p. 33, 1848.

1 Tuomey, Michael, Acad. Nat. Sci. Philadelphia Proc., vol. 6, p. 193, 1852

12 Conrad, T. A., Acad. Nat. Sci. Philadelphia Proc. vol. 17, p. 72. 1865.

${ }^{13}$ Clark, W. B., Geol. Soc. America Bull., vol. 1, pp. 537-540, 1890. 
Stanton ${ }^{14}$ visited the Wilmington locality and noted "the existence of a highly fossiliferous Cretaceous stratum in contact with the Tertiary." He regarded this as "the one fact needed to complete the explanation of mechanical mingling of the faunas."

The most comprehensive study of the Coastal Plain of North Carolina is presented in volume 3 of the North Carolina Geological and Economic Survey, 1912. The investigation was conducted under the direction of William Bullock Clark, of Johns Hopkins University, and presents the results of extended field work by L. W. Stephenson, of the United States Geological Survey, and B. L. Miller, of Lehigh University. Stephenson devoted his attention to the Cretaceous and Pleistocene formations; Miller to the Tertiary formations. The present study is concerned only with the Tertiary section of North Carolina. That part of the report alone is therefore summarized below.

As has been outlined in the foregoing pages, previous investigators had recognized Eocene, Miocene, and Pliocene beds in the Tertiary deposits of North Carolina. Further subdivision had never been attempted, though the possibility of breaking these major divisions into smaller units had been suggested by Emmons as early as 1875 . The more extensive and detailed work carried on by the United States Geological Survey in cooperation with the North Carolina Geological Survey between 1905 and 1912 made it possible to distinguish a number of subdivisions within the major Tertiary units. The strata that had been lumped as Eocene were, on the basis of fossils and lithologic character, divided into two formations. The name Trent was proposed for what was considered the older of these two, and Castle Hayne for the younger. The Miocene strata were separated into three formations. The Miocene north of the Hatteras axis was divided into two formations, the older of which was recognized as the southward extension of the St. Marys formation of Maryland and Virginia and the younger as the southward extension of the Yorktown formation, which receives its name from the town of Yorktown, Va. For the Miocene deposits south of the Hatteras axis, which were considered to be in part contemporaneous with the Yorktown formation, the name Duplin was proposed, because of their excellent development in Duplin County, N. C. The Pliocene was considered a single formation and named the Waccamaw.

As the Trent and Castle Hayne formations constitute the basis of the present investigation, the previous work on these formations will be set forth somewhat at length. When the name Trent was proposed; in 1912, no specific station was given as the type locality. It was stated that "the Trent

" Stanton, T. W., Cretaccous and Tertiary strata near Wilmington, N. C.: Am. Gcologist, vol. 7, pp. 333-334, 1891. formation receives its name from the Trent River, along which it is exposed from the vicinity of Trenton, Jones County, to near the junction of the Trent and Neuse rivers." The Trent formation was believed to underlie the Castle Hayne formation, though the two had never been observed in the same vertical section. Little or no work had been done on the Trent fauna at that time, and the age determination of the formation was based entirely on the identification, by M. W. Twitchell, of four echinoids which he believed "to indicate the Upper Claibornian" age of the strata." They are Scutella alta Conrad, Echinocyamus parvus Emmons, Cidaris carolinensis Emmons, and Cidaris mitchelli Emmons. The exact locality at which these forms were collected is not known. Emmons gave the very indefinite locality of "Craven County, N. C." Three of the species have not been recognized elsewhere and are therefore of little value for determining the age of the beds. The fourth, Echinocyamus parvus Emmons, has been found in Onslow County associated with typical Castle Hayne fossils. The evidence on which the Trent was referred to the Claiborne is therefore. without significance.

In the report of the State Survey published in 1912, 23 field stations referred to the Trent marl are described in detail. Although fossils were observed at most of these localities, they were not specifically identified. In the field investigation for the present report these localities were revisited and fossils were collected which subsequently have been determined. Of the 23 stations listed as Trent localities, seven failed to yield fossils and seven proved to belong to the Castle Hayne formation.

The Castle Hayne marl was named from the town of Castle Hayne, in New Hanover County, near which it is typically exposed. When this formation was separated from the Trent there had been no systematic study of its fauna with a view to determining the age. It was defined as constituting "the youngest Eocene strata of North Carolina" and consisting of "calcareous marls, fossiliferous limestones, and conglomerates that are extensively developed in Onslow, Pender, and New Hanover counties." The present analysis of the rather large fauna correlates the Castle Hayne with the Ocala limestone of Florida, the marls of Santee River, South Carolina, and the Jackson formation of Mississippi.

In 1919 G. D. Harris ${ }^{15}$ described two Pectens from the Trent marl. One of these was new, and to this he gave the name Pecten trentensis. This was the first fossil from the Trent to be described, and Harris remarks that it "is so different from anything we have heretofore found in the Eocene of this part of

\footnotetext{
is Barris, G. D., Bull. Am. Paleontology, vol. 8, pp. 15-16, 1919.
} 
the United States, owing to a lack of well-known species from the same locality, its horizon must at present be considered as doubtful."

The other. Pecten Harris referred with a question mark to $P$. elixatus Conrad, which he considered synonymous with $P$. poulsoni Morton, a Vicksburgian species. Sensing the significance of this identification, Harris says, "It would seem that a considerably greater geologic range should be given to this species ( $P$. poulsoni Morton) than has been admitted heretofore, else the horizon on the Trent whence these specimens came is far higher than has been suspected." These observations assume the greatest interest in view of the discovery set forth in this paper that the Trent marl is of lower Miocene age.

A report by Loughlin, Berry, and Cushman ${ }^{18}$ on the limestones and marls of North Carolina, 1921, describes in detail the deposits of the Trent and Castle Hayne marls. These authors observe that because of "the excellence and quantity of the marls, as well as their accessibility, the Trent formation is the most important of any of the geological formations of eastern North. Carolina." The stratigraphy of the Coastal Plain set forth in the report is essentially the same as that of the report of 1912.

\section{STRATIGRAPHIC RELATIONS}

In interpreting the stratigraphic succession of the Coastal Plain in North Carolina the field geologist is hampered by the scarcity and unsatisfactory character of the outcrops. This region of low relief that borders the Atlantic seacoast is covered with a blanket of unconsolidated Pleistocene sand that effectually conceals most of the older sediments. The exposures of these sediments are found chiefly along the larger streams where the surface sand has been cut through or in artificial excavations where the older formations are being exploited. The sediments of the Tertiary formations are in general soft or where consolidated show little or no evidence of stratification. The beds are essentially horizontal, and the slight dip can never be observed in the outcrops. Another difficulty is the state of preservation in which the organic remains are usually found. The fossils of the Castle Hayne and Trent formations are with few exceptions preserved as casts, and a casual examination of such material gives little information regarding the age. The fact that the Trent and Castle Hayne have never been recognized in the same vertical section is probably due to this condition of the fossils.

Prior to this investigation students of the stratigraphy of the Coastal Plain of North Carolina have considered the Trent marl to be of Eocene age: It has been believed to represent the Claiborne epoch of the Eocene and therefore to lie beneath the Castle Hayne

10 Loughlin, G. F., Berry, E. W., and Cushman, J. A., North' Carolina Geol. and Econ. Survey Bull. 28, 1921. marl, which was referredito.the-Jackson epoch. The geologic map of the Coastal Plain of North Carolina published in 1912 shows the general areal position of the formations, in order from southwest to northeast, the Peedee, Castle Hayne, Trent, and Miocene formations. The age succession was therefore Cretaceous, Jackson, Claiborne, and Miocene. It thus appeared that the beds do not lie from southwest to northeast in the regular order of their age, but that the Trent and Castle Hayne formations are in reversed position.

The accompanying map (fig. 1) indicates the stations at which Castle Hayne and Trent fossils have been collected. It will be observed that the Castle Hayne marl extends from the vicinity of Wilmington northward and northeastward to Neuse River and that the Trent has been recognized at a few localities just east of the Castle Hayne area. The contact between the two follows in general a north-south line and is therefore approximately parallel to the areal contacts of other Tertiary formations in North Carolina. The analysis of the Trent fauna given in this paper shows the Trent formation to be of lower Miocene age, instead of Eocene, as it has previously been considered. It is obvious, therefore, that the Trent overlies the Castle Hayne formation, which belongs to the Jackson epoch of the Eocene. With this revision of the stratigraphic succession and areal distribution of the formations, it becomes clear that the formations lie in the regular order of their age, from older to younger, northeastward from the CretaceousCastle Hayne boundary. The order of succession is then Cretaceous, Eocene, lower Miocene, and upper Miocene.

In the vicinity of Wilmington,. New Hanover County, the Cretaceous beds extend eastward to a point within 10 miles of the coast. From this point the shore line of the Eocene sea extended almost due north. The Castle Hayne deposits, now confined to a small triangular area between Neuse River and Wilmington, were probably laid down over a much larger area extending to the north and east. The succeeding Trent sea, invading from the east, overlapped the Castle Hayne sediments as far westward as Jacksonville, Polloksville, and the vicinity of Batchelder Creek. At the present time the Trent deposits are exposed in a narrow north-south belt between New and Neuse rivers. They do not crop out north of Neuse River, but there is no reason to suppose that they were not laid down over an extensive area north and east of their present areal boundaries. In the next submergence, during which the St. Marys formation was laid down, the sea extended farther west than any of the preceding seas and overlapped all the earlier formations as far as the Piedmont belt in Wilson, Nash, and Halifax counties. Toward the south it covered the Cretaceous deposits to the vicinity of Jason, Fields, and Quinerly, 


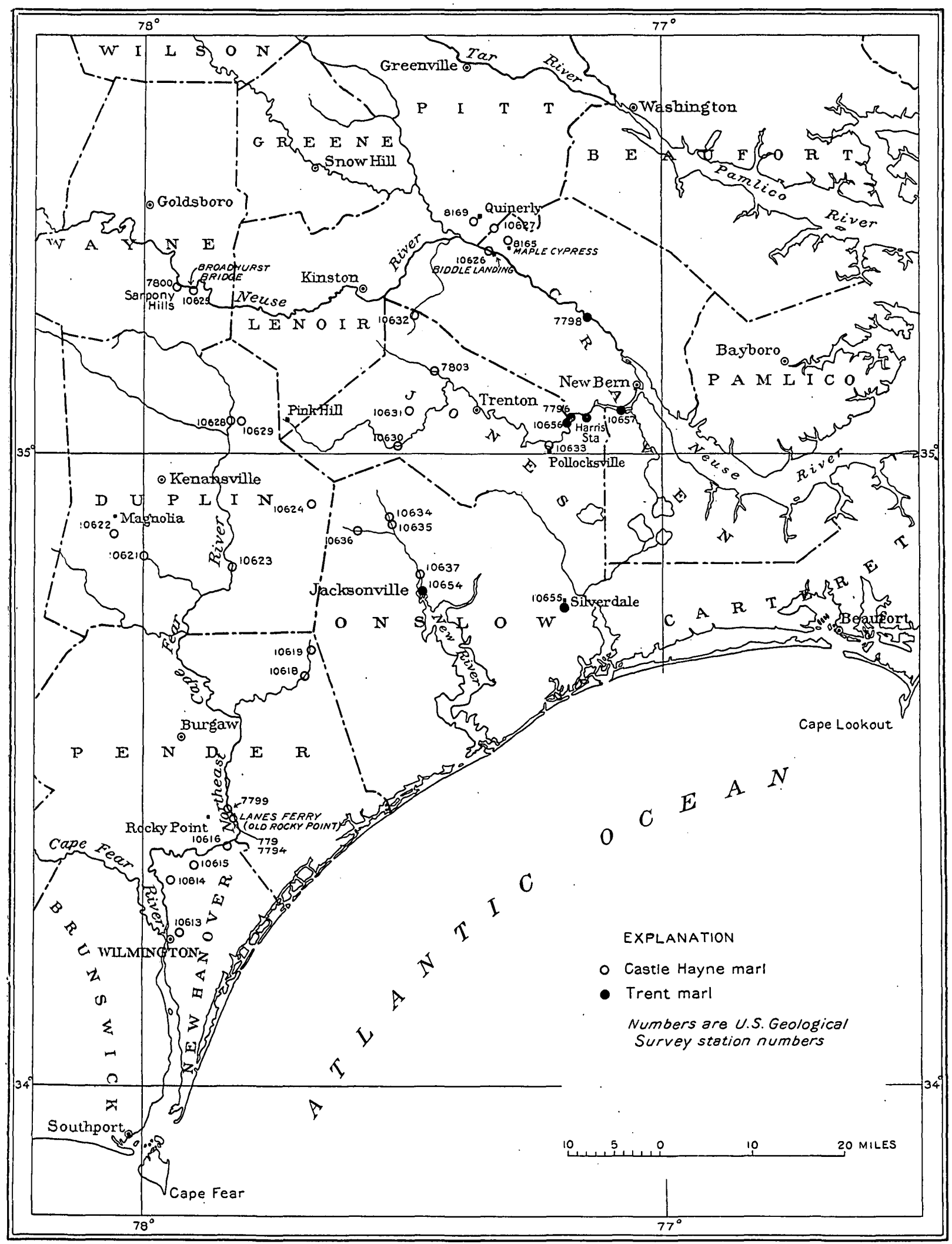

FIGURE 1.-Index map showing field stations in the Castle Hayne and Trent marls

$51278-26 \dagger-2$ 
and farther east it overlapped the Castle Hayne and Trent formations north of Neuse River. The extent of the overlap of the St. Marys sea on these formations has not been observed, because subsequent Miocene deposits overlapped that boundary and rest directly on the Castle Hayne and Trent as far south as Neuse River.

The Tertiary history of the Coastal Plain of North Carolina includes a succession of oscillations of the Atlantic strand line. After each of the major transgressions of the sea, which are represented by successive geologic formations now found in the area, the sea withdrew and active erosion set in. The deposits that had been laid down were carved and channeled by subsequent streams flowing to the sea across the lately exposed plain. This activity is recorded in the sediments of the Coastal Plain to-day by erosional contacts between successive formations. Such unconformities explain the occurrence of isolated patches of one formation in pockets or depressions of an older formation. They also explain the absence of a formation in a section that comprises older and younger sediments. This condition has made the mapping of the Coastal Plain formations extremely difficult, with the result that the most carefully executed map can only be a rough approximation of the truth.

\section{ANALYSIS OF THE CASTLE HAYNE FAUNA}

\section{GENERAL CONSIDERATIONS}

The fauna of the Castle Hayne marl has received sporadic attention from paleontologists. Fossiliferous localities at Wilmington, Castle Hayne, and Rocky Point have frequently been visited by collectors, and fossils from the Eocene at these places have been described and figured from time to time. Most of the organic remains preserved are in the form of casts, but these include both the exterior and the interior of many species of the shells. In certain groups, such as echinoids, oysters, pectens, brachiopods, and Bryozoa, the original shell material is perfectly preserved. In the present investigation fossils have been collected at many new localities, but none of these have yielded the great variety of forms obtained at Wilmington and Rocky Point. The groups represented at these new stations are principally the more resistant forms such as pectens, echinoids, and Bryozoa. The Bryozoa from Wilmington have been exhaustively treated by. Canu and Bassler. ${ }^{17}$ The evidence for correlation presented by this group of organisms is taken from their work. All the Bryozoa collected from new localities have been identified by Doctor Bassler.

17 Canu, Ferdinand, and Bassler, R. S., North American early Tertiary Bryozoa U. S. Nat. Mus. Bull. 106, 1920.

\section{BIOLOGIC ANALYSIS}

The Castle Hayne fauna is both abundant and varied. During the present study 305 species and varieties have been recognized, of which 214 are Bryozoa. The collections have been made over a long period of time and are believed to constitute a fair representation of the total fauna. They have been taken from several large quarry excavations and also from many widely scattered localities. In the 305 species and varieties recognized there are 12 species and 1 variety of Echinoidea, 31 species of Pelecypoda, 36 of Gastropoda, 2 of Cephalopoda, 5 of Brachiopoda, and 4 of Anthozoa.

The Echinoidea form one of the most important groups of the fauna. They usually occur in a perfect state of preservation and are widely distributed geographically throughout the formation. The class is represented by five families and nine genera. The Cassidulidae, represented by two genera, are most abundant in individuals and of widespread occurence. The Scutellidae, represented by the single species Periarchus lyelli Conrad, are second in abundance. This species is the commonest echinoid in the fauna and during the field investigation served as a signpost of the Castle Hayne formation. The family Spatangidae is represented by four genera, each except Linthia by only a single species and present only at Wilmington. The Cidaridae and Fibulariidae are very minor groups.

All three orders of the Pelecypoda are well represented in the fauna. Among the Prionodesmacea the Pectinidae are by far the most abundant. Although they here include only. the single genus Pecten, they contain a larger number of species than any other family of the Pelecypoda: Of the six species referred to Pecten, three are new, one is known from a single locality outside of the Castle Hayne formation, and the other two are the well-known Eocene species $P$. deshayesii Lea and $P$. scintillatus Conrad. P. membranosus Morton is the most abundant, the most widespread, and the most characteristic fossil of the Castle Hayne marl. It has been found at 16 of the 29 stations referred to this formation. P. cookei Kellum is also a very common form, occurring at 10 stations.

The Ostreidae are second in abundance among the Prionodesmacea, being represented by four species of the genus Ostrea. 0 . alabamiensis subsp. georgiana Conrad has been found only at Polloksville, Jones County, but at this place it forms a solid bed of rotten shell, as much as 12 feet in thickness, and crops out at numerous points within a radius of about a mile. Ostrea trigonalis Conrad and $O$. sellaeformis Conrad are very common species in the Castle Hayne formation. They are usually small, but some individuals of $O$. trigonalis attain a length of 3 inches. A single speci- 
men is referred to 0 . falco Dall. It is interesting to find this remarkably distinct species so far from its type locality, the "Zeuglodon bed" of Choctaw County, Ala.

The Spondylidae are represented by two genera, Spondylus and Plicatula. S. lamellacea Kellum is of special interest because it is so unlike any species of Spondylus heretofore found in the Tertiary. With its peculiar sculpture of coarse, raised lamellae it resembles the Cretaceous species $S$. gregale (Morton). The Arcidae and Anomiidae are relatively insignificant.

The order Anomalodesmacea includes two families, the Pholadomyidae and Euciroidea. They are represented by a single species each and are not abundant in individuals. Pecchiolia dalliana. Harris was found at three localities and is of interest because of the rare occurrence of this genus in the American Tertiary deposits.

The Teleodesmacea are represented by seven families and eight genera. Although well developed in the fauna, all the species are preserved as casts, and none are found at more than two localities. Meiocardia carolinae Harris should receive special mention as the first occurrence of this genus to be reported from the American Tertiary. It is possible that the species should be referred to the genus Veniella instead of Meiocardia, but as it is known only from the internal cast Harris's opinion has been followed in this paper.

The Gastropoda of the Castle Hayne fauna belong to $17^{\prime}$ families and 22 genera. They are preserved almost entirely as casts and their specific identification has been made with great caution. Of the 36 species recognized, 5 are new and 23 have received only generic determination. The Gastropoda, with the exception of 2 species, are confined to the Wilmington and Rocky Point localities.

The entire assemblage of univalves belongs to the subclass Streptoneura. The order Aspidobranchia is represented by three families, Pleurotomariidae, Fissurellidae, and Trochidae, of which the Pleurotomariidae are the most abundant. Two indeterminate species of Pleurotomaria attain greater size than any other forms of the fauna.

The Ctenobranchiata are segregated into three superfamilies. Among the Ptenoglossa the Epitoniidae are perhaps the most interesting. They are represented by two new species of Epitonium. These highly sculptured individuals are the only gastropods which have the original shell preserved. The Cassididae, represented by the genera Cassis and Phalium, are fairly common. The Cypraeidae, including five species of the genus Cypraea, are the most prolific forms of the Ptenoglossa, with the possible exception of the Vermiculariidae, represented by the single species Siliquaria vitis Conrad. The five remaining families of the Ptenoglossa (Capulidae, Naticidae,
Turritellidae, Cerithiidae, and Strombidae) are poorly represented in the fauna.

Of the four families belonging to the superfamily Rachiglossa, the Volutidae are by far the most numerous. They are represented by five genera. An indeterminate species of Marginella is the most common form. The genus Plejona includes two species of rare occurrence. Under the genus Mitra six species have been discussed. These are all preserved as internal casts and are doubtfully referred to this genus. Scaphella and Caricella are each represented by a single species and are rather uncommon. The Vasidae in the species Vasum wilmingtonense Brown and Pilsbry and the Fasciolariidae in the species Fusinus abruptus (Tuomey) attain conspicuously large dimensions. The Buccinidae are unimportant.

The family Conidae is the only representative of the Taxoglossa. It includes two species of Conus, which are fairly abundant in the fauna.

Two species of Cephalopoda occur in the Castle Hayne assemblage. Although not widespread throughout the formation both of them are very abundant at the two or three stations where they occur. Aturia alabamenis (Morton) was originally described from specimens found in the Eocene at Claiborne, Ala., and individuals from the type locality are indistinguishable from those of the Castle Hayne. Nautilus carolinensis Kellum has been identified by other students as $N$. dekayi Morton, from the Cretaceous of New Jersey. It is here recognized as a separate species on account of the essentially straight course of the sutures across the venter. The sutures of the Cretaceous species have a broad saddle along the venter.

The Brachiopoda of the Castle Hayne marl form one of the most interesting groups of the fauna. The group is represented by three genera and five species, a greater number than has been reported from any other Tertiary formation on the east coast. Terebratula wilmingtonensis Lyell and Sowerby is second only to Pecten membranosus Morton in abundance of individuals. The species is remarkably variable in form, and variations of it have been described by several authors under different specific names. A large number of specimens, however, show perfect gradations between the most widely differing forms. The species was found at four localities. Terebratula crassa Kellum does not occur at Wilmington and has been reported from only one station in Lenoir County, where it is associated with Pecten membranosus Morton and other Castle Hayne fossils. Terebratulina lachryma (Morton) is more widely scattered throughout the formation than any other brachiopod but it is not abundant. Rhynchonella salpinx Dall and Rhynchonella holmesii Dall occur only at the Wilmington locality and are very uncommon. 
The following corals from the Castle Hayne are listed in the State report of 1912 as identified by T. Wayland Vaughan: Flabellum sp., Madracis sp., Endopachys maclurei (Lea), Balanophyllia sp. No subsequent work has been done on this group of organisms.

\section{CORRELATION}

In 1912 Miller ${ }^{18}$ referred the Castle Hayne marl to the "upper Eocene horizon" of North Carolina. As little study had been given to the fauna at that time, no attempt was made to correlate the formation with other Eocene formations of the Coastal Plain. The Castle Hayne was first referred to a definite horizon in the Eocene by Cooke ${ }^{19}$ in 1916. He briefly stated that two fossils listed by Dall from the Ocala limestone of Florida "apparently occur also in the Castle Hayne limestone at Wilmington, N. C., which is of Jackson age."

In 1920 Canu and Bassler ${ }^{20}$ made an exhaustive study of the Bryozoa from the Castle Hayne at Wilmington. They recognized 214 species and varieties from this locality, of which 169 were new and 88 were limited to the Castle Hayne formation. Through this study the Castle Hayne was assigned to the middle Jackson horizon of the Eocene, and was correlated with the Cooper marl of South Carolina, the Ostrea georgiana zone at the base of the Barnwell formation of South Carolina, and the Tivola tongue of the lower part of the Ocala limestone of Georgia.

The evidence presented by the other groups of organisms in the Castle Hayne fauna confirms this correlation. The poor state of preservation of most of the fossils, however, together with the relatively large number of new forms and the long range of some of the species, greatly limits their value in correlation. In the following list of fossils from the Castle Hayne marl that have been specifically identified those that have been found also in other formations are so indicated; the others have been found only in the Castle Hayne.

Cidaris pratti.

Echinocyamus parvus.

Periarchus lyelli. Claiborne, Jackson.

Cassidulus raveneli. Jackson.

Cassidulus carolinensis.

Cassidulus carolinensis var. craveni.

¿Cassidulus berryi.

Echinolampas appendiculatus.

Hemipatagus subrostratus.

Linthia wilmingtonensis.

Linthia hanoverensis.

Eupatagus carolinensis. Ocala limestone, Jackson.

18 Miller, B. L., North Carolina Geol. and Econ. Survey, vol. 3, 1912, p. 185.

10 Cooke, C. W., The age of the Ocala limestone: U. S. Geol. Survey Prof. Paper 95, p. 111, 1916.

${ }^{20}$ Canu, Ferdinand, and Bassler, R. S., North American early. Tertiary Bryozoa: U. S. Nat. Mus. Bull. 106, 1920.
Macropneustes carolinensis.

Arca cancellata? Ocala limestone, Jackson.

Ostrea alabamiensis subsp. georgiana. Claiborne, Jackson.

Ostrea trigonalis. Ocala limestone, Jackson.

- Ostrea sellaeformis. Claiborne, Jackson?

Ostrea falco? Jackson of Alabama.

Ostrea subeversa. Cretaceous (?) to Jackson.

Pecten membranosus. Jackson, Eutaw Springs, S. C.

Pecten deshayesii. Claiborne, Jackson.

Pecten scintillatus. Claiborne, Jackson.

Pecten cushmani.

Pecten cookei.

Pecten biddleana.

Plicatula filamentosa. Claiborne, Jackson.

Spondylus lamellacea.

Pholadomya claibornensis. Claiborne.

Pecchiolia dalliana.

Crassatellites alta. Claiborne, Jackson.

Venericardia nasuta? Type locality doubtful.

Phacoides pandatus? Claiborne, Jackson.

Meiocardia carolinae.

Pitaria securiformis. Jackson.

Pleurotomaria hanoverensis.

Fissuridea penderensis.

Epitonium aequabile.

Epitonium dignitatis.

Turritella subtilis.

Siliquaria vitis. Claiborne to Tampa.

Fusinus abruptus?

Vasum wilmingtonense.

Plejona conoides?

Scaphella ocalana. Ocala limestone, Jackson.

Conus mutilatus?

Aturia alabamensis. Claiborne, Jackson. ।

Nautilus carolinensis.

Rhynchonella salpinx.

Rhynchonella holmesii.

Terebratula wilmingtonensis.

Terebratula crassa.

Terebratulina lachryma. Ocala limestone, Jackson.

Endopachys maclurei. Claiborne, Jackson.

An examination of this list shows the fauna to have very strong Jackson affinities. Of the 53 species identified, 30 are limited to the Castle Hayne marl, 8 are limited to the Jackson horizon in other regions, and all except 2 are known to range through the Jackson. Presenting the correlation data in tabular form, we have:

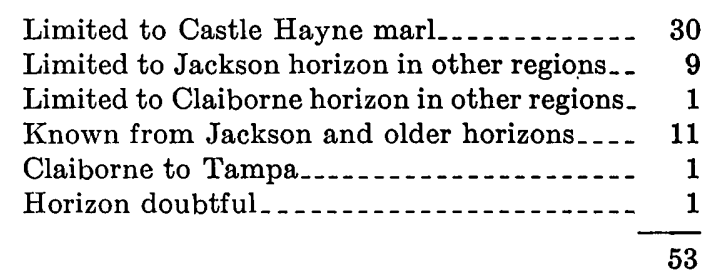

The conclusion drawn from this analysis is that the evidence presented by the Echinodermata, Pelecypoda, Gastropoda, Cephalopoda, and Brachiopoda shows that the Castle Hayne marl has its strongest affinity with the Jackson horizon of the Eocene. 
FIELD STATIONS OF THE CASTLE HAYNE MARL

The conclusions of this paper regarding stratigraphy of the Coastal Plain of North Carolina are based on detailed observations at scattered stations over the area (see fig. 1), on a general reconnaissance of the region underlain by the Trent and Castle Hayne marls, and on a careful study, in the laboratory, of the fossils collected from these horizons. In order that the evidence for the conclusions reached may be complete, detailed descriptions of the stations visited are given below. The fossils found at each station, except the Bryozoa, are shown in the table on page 11 .

$\operatorname{10613}^{21}(=782,3602,3609,4285,4287,5611,7302,7316$, 7797a, 7797c, 7802, 7808, 7818). East side of Wilmington, New Hanover County; City Rock quarry, near Smith Creek. The following section is copied from Miller: ${ }^{22}$

Pleistocene: Sandy soil_._._._. Ft. in.

Miocene: Thin isolated patches of Miocene shell marl in depressions in irregular eroded surface of the Eocene. The maximum thickness observed ... Eocene (Castle Hayne) :

Calcareous marl full of holes of solution which are filled with clay. In some places the marl is quite firmly cemented.

Fragmented shell rock; few entire shells found. Upper part cemented to form hard rock; lower,

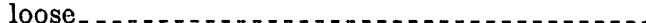

Pebble layer with waterworn black pebbles firmly cemented. Contains many shark teeth_ 3-4

10614. $31 / 2$ miles northwest of Wrightsboro, New Hanover County, on farm of Walter Carr. In a vertical bank, 5 to 10 feet thick and extending horizontally for about 100 feet, the following section is exposed:

Pleistocene or Recent: Yellow unconsolidated earth ..... 3-6

Miocene (Duplin marl): Rotten shell marl, composed chiefty of calcareous shells in a matrix of yellow sand; locally _... . . . . .

Erosional unconformity.

Eocene (Castle Hayne marl): Yellow earthy or sandy marl, streaked with iron stain, containing few fossils; reported to have a high phosphate content.......... 3-7

The erosional contact at the top of the Eocene bed is very marked. The Miocene shell marl does not extend continuously over the Eocene but occupies depressions or pockets in its upper surface.

$10615(=3611,4286)$. Castle Hayne rock quarry, half a mile south of Castle Hayne railroad station, New Hanover County. A section of about 18 feet is exposed in the quarry, as follows:

Pleistocene: Gray and yellow loose sand of varying texture, about................. Eocene (Castle Hayne marl):

White and grayish-white marl containing some fossils . . . . 2 $21 / 2$

Coarse conglomerate of green and black phosphate pebbles with sandstone and quartz pebbles cemented by lime . . .

Cretaceous: Brownish-yellow impure limestone made up almost entirely of casts of marine mollusks. .....

21 Tertlary locality numbers above 10000 are recorded in the United States Geo. logical Survey station books and on the specimens in fractional form-for example, 360 ( $\square 10403)$

82 Miller, B. L., North Carolina Geol, and Econ. Survey, vol. 3, p. 191, 1912.
10616. Left bank of Northeast Cape Fear River about 31/2 miles upstream from the Castle Hayne Bridge, Pender County, on the Bob Bourdeau tract. An outcrop of loosely consolidated yellow earthy marl, 5 to 7 feet thick, extends along the river's edge for about 100 feet.

779 (=7794). French Brothers' quarries at old Rocky Point, now known as Lanes Ferry, on Northeast Cape Fear River, 3 miles east of Rocky Point Station, Pender County. This is the locality visited by earlier investigators, including Charles Lyell, W. B. Clark, T. W. Stanton, and L. W. Stephenson. Stephenson ${ }^{23}$ described the section as revealed by the old pits as follows:

\section{Section at old Rocky Point quarries}

Surficial brown sandy clay -

Eocene (Castle Hayne marl):

Dark yellow to greenish disintegrated limestone stained more or less with iron . . . . . . . . . . . Soft white limestone or marl with many fossils....

Hard white limestone................................

Conglomerate composed of phosphatic pebbles or nodules up to 2 inches in diameter, shark teeth, and mollusks, cemented with calcium carbonate.. 2

The different layers varied somewhat in thickness from pit to pit. Stanton in 1891 determined the presence of a gray calcareous sandstone of Cretaceous age underlying the Eocene conglomerate in some of the deeper pits at this locality.

10618. 1 mile south of Maple Hill post office, Pender County, on farm of J. C. Wooten. Extensive marl pits of sof't whitishyellow marl, containing an abundance of Bryozoa and a few other fossils.

10619. Moors Creek, 2 miles west of Angola post office and 3 miles northeast of Maple Hill post office, Pender County, on farm of J. L. Fisher. Old shallow pits in the low ground bordering the creek expose whitish-yellow sandy marl. The marl contains an abundance of Bryozoa, some pectens, echinoids, and oysters.

7799. 1 mile northwest of Lanes Ferry over Northeast Cape Fear River, Pender County, on farm of R. G. Ross. This station was visited by L. W. Stephenson in 1906, and the following description of the exposure is taken from his field notes: "Along a small branch and near a strong spring the Eocene limestone and phosphate rock is seen to outcrop. It is here overlain by a foot or more of rotten limestone. On the opposite side of the stream from the spring a small outcrop of the latter, a few feet square, was discovered which was very full of fossils, principally oval sea urchins, gastropods, corals."

10621. $1 \frac{1}{2}$ miles northeast of Rose Hill station, Duplin County, on farm of A. R. Bland. Bluish-white marl, consisting chiefly of ground shell, is exposed in a large pit, 10 feet deep, 30 feet long, and 15 feet wide. The marl has been exploited commercially, a small gasoline engine being used to raise the marl from the pit, but the project has not proved a financial success.

10622. 2 miles south of Magnolia, Duplin County, on farm of B. D. Johnson. Bluish-white soft fine-grained marl is exposed in numerous shallow pits, where it has been dug for f'ertilizer. The marl contains many echinoids, pectens, Bryozoa, fish teeth, etc.

10623. 100 yards below Chinquapin Bridge, on left bank of Northeast Cape Fear River, Duplin County. At this station an outcrop of hard impure whitish-yellow speckled limestone, about 4 feet thick, projects from the bank. It is made up almost entirely of casts of marine shells. The outcrop can be followed for about 50 feet upstream from this point and is seen to grade into soft marl. The marl, which has been dug for fertilizer, is made up for the most part of finely-ground shell. At the sur-

${ }^{23}$ Unpublished notes. 
face, where the marl has been exposed to the air, it is yellow; but below, where the marl is saturated with water, it is light blue.

10624. Cedar Fork Swamp, 5 miles east of Beulaville, Duplin County. White and bluish-white mard, apparently almost pure lime, is exposed in pits 5 to 10 feet deep. The marl is solid and heavy when first dug but on exposure to the air dries out, becomes almost pure white, and has an extremely fine texture. The fossils listed in the table are abundant in individuals. The deposit is covered only by a mantle of swamp soil, underlies a large area, and is very accessible. It has been dug extensively and used locally for fertilizer.

10625. Near the mouth of a small creek, 150 yards southwest of Broadhurst Bridge on Neuse River, Wayne County. The outcrop is exposed along the bed and side of the creek for a distance of 100 feet. The stream has cut into a soft whitishyellow ground-shell marl to a depth, locally, of 3 feet.

7800. Sarpony Hills, right bank of Neuse River at milepost 83, Wayne County. The following section was measured at this station by B. L. Miller:

Pleistocene: Talus-covered slope

Feot

Eocene (Castle Hayne marl):

White to greenish-white soft limestone containing some fossil casts. Pecten is common. Limestone contains some glauconite.

Greenish-blue hard argillaceous limestone with echinoid spines, portions of echinoid tests, etc

40

10626. Biddle Landing, right bank of Neuse River, due north of Fort Barnwell, Craven County.

1062\%. 3 miles east of Quinerly and 2 miles north of Neuse River, in Pitt County, on farm of T. J. Falkner. Bluish-white marl of extremely fine texture and high lime content, containing some well-preserved fossils. The marl has been excavated extensively for fertilizer.

8169. Drainage canal just south of Quinerly Bridge, Clayroot Swamp, Pitt County. This station was visited by Joseph A. Cushman, who collected the fossils listed in the table from the marl exposed in the canal.

10628. 6 miles west of Pink Hill, Lenoir County, on farm of H. J. Williams. Soft bluish-white marl, of fine texture, containing a few well-preserved shells, has been quarried extensively for fertilizer. The fossils listed in the table were collected from a pile of the marl that had been thrown out and exposed to the weather for several years.

10629. 5 miles west of Pink Hill, Lenoir County, on farm of B. F. Smith. At this locality a whitish-yellow marl was dug several years ago and used for fertilizer. The marl is overlain by 10 feet or more of yellow earthy sand and is poorly exposed in the old pits.

10630. Right bank of Trent River three quarters of a mile southwest of Comfort depot, Jones County, on farm of Miss Sally Simmons. In a vertical bluff 25 feet high, extending for 500 feet along the right side of the river, the following section is exposed:
Pleistocene: Soft, unconsolidated gray sand ........... Eocene (Castle Hayne marl):

Bluish-gray sticky clay, unfossiliferous............

Yellow ground-shell marl, with sandy matrix, containing Bryozoa and Pecten deshayesii Lea in abundance and Periarchus lyelli (Conrad) rarely . -

Hard yellow impure limestone, with numerous casts of fossils.

Light-blue soft marl that turns yellow on exposure to the air; contains a few poorly preserved shells..

Feet

3

3

5

5

10631. Right bank of Little Chinquapin Creek half a mile northwest of Wimsatt, Jones County, on farm of D.W. Dudley. Whitish-blue marl, containing many Bryozoa and a small variety of other fossils. The marl has been quarried and used locally for fertilizer.

10632. $21 / 2$ miles west of Dover Station, Jones County, on farm of J. L. Bryan. Grayish-white sandy marl was observed in several shallow pits, which had been dug a number of years ago.

7803. Beaver Creek, 2 miles northwest of Wilcox Bridge over Trent River, Jones County. This station was visited by B. L. Miller, who collected the fossils listed in the table.

10633 (=7809). North end of Atlantic Coast Line Railroad bridge over Trent River at Polloksville, Jones County. In a vertical bank 20 to 25 feet high, which extends along the river about 100 feet, the following section is exposed:

Pleistocene: Buff to pinkish-yellow unconsolidated sand _ - 3-10 Eocene (probably Castle Hayne marl: Solid bed of rotten

oyster shells in a matrix of buff sand.............. 15

10634. 1 mile southeast of Richlands station, Onslow County, on farm of Lee Frank. Whitish-yellow sandy marl, containing many Bryozoa and Pectens. A single specimen of Terebratulina lachryma Morton was found. The fossils listed in the table were collected from large piles of freshly dug marl.

10635. On Cow Horn Creek, $11 / 2$ miles southeast of Richlands station, Onslow County, on the old Sandlin property. In a belt of woods bordering the creek about 150 yards west of the "old" road from Jacksonville to Richlands, a number of old marl pits were visited. A fresh exposure of the marl was not observed, as the pits had slumped in and partly filled with soil. Numerous fragments of Pecten membranosus Morton and Kleidionella grandis Canu and Bassler, picked up in the weathered marl about the pits, indicate the formation to be the Castle Hayne.

10636. 10 miles northwest of Jacksonville, Onslow County, on the farm of J. M. Thomas. A large outcrop of consolidated yellow ground-shell marl, about 10 feet thick, extends horizontally around the nose of a low hill for 150 feet.

1063\%. 2 miles north of Jacksonville, Onslow County, on the farm of E. W. Sabiston. Yellow ground-shell marl, locally consolidated into hard, impure limestone, is exposed in old pits that have been dug extensively along a small creek.

The following table does not include the Bryozoa, which are listed by Canu and Bassler in the bulletin already cited. 
Echinoid; mollusks, and brachiopods from the Castle Hayne marl

\begin{tabular}{|c|c|c|c|c|c|c|c|c|c|c|c|c|c|c|c|c|c|c|c|c|c|c|c|c|c|c|c|c|}
\hline & 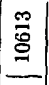 & 营 & $\stackrel{\square}{\stackrel{0}{\sharp}}$ & 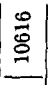 & 量 & 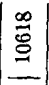 & $\stackrel{\Phi}{\ddot{\Xi}}$ & 总 & चू్ & 范 & 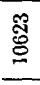 & 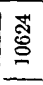 & đूँ & 喿 & $\stackrel{\square}{0}$ & $\begin{array}{l}8 \\
0 \\
0 \\
\end{array}$ & 太્ષ્ & 离 & . & $\stackrel{0}{0}$ & $\begin{array}{l}\overrightarrow{0} \\
\stackrel{0}{\circ} \\
\end{array}$ & 芯 & 㴫 & 兽 & 范 & 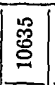 & : & 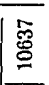 \\
\hline daris pratti Clark & $x$ & & & & & & & & & & & & & & & & & & & & & & & & & & & \\
\hline 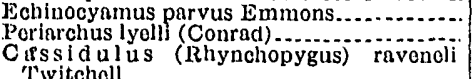 & $\left|\begin{array}{c}x \\
x\end{array}\right|$ & & & $x$ & & & $x$ & & ... & $x$ & & & & & & & & $\ldots$ & $\cdots$ & $x$ & $x$ & & & . & & $\cdots$ & $x$ & $\cdots$ \\
\hline $\begin{array}{l}\text { Twitcholl (Rhynchopygus) carolinensis } \\
\text { Cassidulus } \\
\text { Twitchell }\end{array}$ & $x$ & & & & $x$ & & & & & & & & & & & & & & & & & & & & & & & $x$ \\
\hline $\begin{array}{l}\text { Cassldulus (Pygorhynchus) carnlinensis } \\
\text { var. craven Kellum }\end{array}$ & $x$ & & & & & & & & & & & & & & & $x$ & $x$ & & & & & & & & & & & \\
\hline $\begin{array}{l}\text { Zassidulus (Pygorhynchus) berryi Kellum.. } \\
\text { chinolampas appendiculatus Emmons..... }\end{array}$ & $x$ & & & $\ldots .$. & $\times$ & & $x$ & & & & & & - & & $x$ & $x \mid$ & $x \mid$ & & & & & & & & & & & $x$ \\
\hline Hom & $\begin{array}{l}x \\
x \\
y\end{array}$ & & $\cdots$ & $\cdots$ & $x$ & 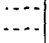 & $x$ & & & & & & & & & & & & & & & $\cdots$ & & & & & & \\
\hline .... & $\mid \begin{array}{l}x \\
x\end{array}$ & & $\cdots$ & $x$ & $\cdots$ & .. & $\cdots$. & & & & & .... & $\ldots$ & (.... & & & $\cdots$ & & & $\cdots$ & & & & & & & & $\cdots$ \\
\hline tark............. & $\left|\begin{array}{l}x \\
x\end{array}\right|$ & & & & $\cdots$ & & $\cdots$ & & & & & & & & & & & & & & & $\cdots$ & & & & $\cdots$ & & \\
\hline - & $|x|$ & & & & & & $\cdots$ & & & & & & & & & & & & & & & & & & & & & \\
\hline (............... & $x \mid$ & & $\cdots$ & $\cdots$ & $\times$ & $\cdots$ & $\cdots$ & & & & & & & $\cdots$ & & & & & & & & $\cdots$ & & $\cdots$ & & $\cdots$ & & \\
\hline $\begin{array}{l}\text { Ostrea alabamiensls subsp. georgiana Con- } \\
\text { raci. }\end{array}$ & & & & & & & & & & & & & & & & & & & & & & & & & & & & \\
\hline $\begin{array}{l}\text { s Conrad } \\
\text { s............................... }\end{array}$ & $\stackrel{x}{x}$ & $\cdots$ & $x$ & $\times$ & $|x|$ & & $\times$ & $\cdots$, & & & & & $\times$ & $x$ & $\underset{x}{x}$ & & $x$ & $x$ & $\stackrel{x}{x}$ & $\cdots$ & $x$ & $x$ & $x$ & $\mid \begin{array}{l}x \\
x\end{array}$ & $\cdots$ & $\cdots$ & $\cdots$ & {$\left[\begin{array}{l}- \\
\cdots-.\end{array}\right.$} \\
\hline $\begin{array}{l}\text { s) membranosus Morton } \\
\text { ) deshayosii Lea. }\end{array}$ & 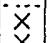 & $x$ & $\dddot{x}$ & $\times$ & $x$ & $\ddot{x}$ & $x$ & {$\left[\begin{array}{c}\cdots \\
\cdots\end{array}\right.$} & $x$ & $x$ & $\cdots$ & $x$ & $\cdots$ & $x$ & $\cdots \cdot>>>3$ & & $x$ & $\cdots \cdot-1 \Rightarrow-1>1$ & $x$ & & & $x$ & & & $-\bar{x}$ & $x$ & $\cdots$ & $\ldots$ \\
\hline $\begin{array}{l}\text { Pecton (Pser } \\
\text { rad........... }\end{array}$ & $x \mid$ & & & & & & & & & & & & & & & & & & & $x$ & $x$ & & $x$ & & & & & \\
\hline Pecton t $^{-1}$ & & & & & & & 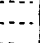 & & & & & & & & & & $x$ & & & & & & & & & & $x$ & \\
\hline 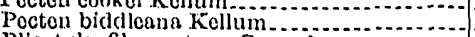 & & & & .... & -- & & $\cdots$ & $\cdots$ & & $x$ & $x$ & & $x$ & $x$ & & & $x$ & $\times$ & & & $\times$ & $\times$ & $\times$ & & & & & $\cdots$ \\
\hline ……. & $x$ & & & & & & $\cdots$. & $\cdots$ & $\ldots$ & & & & & & $x$ & & $\cdots$ & .... & $\cdots$ & & & $\cdots$ & & & & & $x$ & \\
\hline (2........... & & & & $\times$ & $x$ & & & & & & & & & & & & & & & & & & & & & & & \\
\hline Y........... & $x$ & & & & & & $\cdots$ & & & & & & & & $\cdots$ & $\cdots$ & $x$ & $\cdots$ & $\cdots$ & & & & & & & & & \\
\hline rad) & $\begin{array}{l}x \\
x\end{array}$ & & & $\ldots$ & $\begin{array}{l}x \\
x\end{array}$ & & $\cdots$ & $x^{x}$ & & & & & & & $\cdots$ & & S & I & $\cdots$ & & & & & & & & & \\
\hline & & & & & $x$ & & $\cdots$ & & & & & & & & $\cdots$. & & & 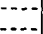 & & & & & & & & & & \\
\hline - & $x$ & & & & $x \mid$ & & $\cdots$ & & $\cdots$ & & & & & & $\cdots$ & & $\cdots$ & $\cdots \cdot$ & & & $\cdots$ & & $\cdots$ & $\cdots$ & & $\cdots$ &. & $\cdots$ \\
\hline & $\left|\begin{array}{l}x \\
x\end{array}\right|$ & & & & & & & & & & & & & & & & & & & & & & & & & & & \\
\hline$\cdots$ & $\hat{x}$ & & & $\cdots$ & $x$ & & -... & -1 & $\cdots$ & & & & & & $\cdots$ & & & $\cdots$ & $\cdots$ & & & & & & & & & $\cdots$ \\
\hline irad)? & $x \mid$ & & $\cdots$ & $\cdots$ & $x$ & & $\cdots$ & & $\cdots$ & $\cdots$ & & & & & $\cdots$ & & $\cdots$ & $\cdots$ & .... & & & & $\cdots$ & -7 & & & & $\cdots$ \\
\hline (n)........ & $\hat{x}$ & & & & $x \mid$ & & $\cdots$ & & & & & & & & $\ldots .$. & & .... & & & & & & & & & & & $\ldots$ \\
\hline . & $\begin{array}{l}x \\
x \\
\end{array}$ & & $\cdots$ & & $x \mid$ & & & 1 & & & & & & & & & (t & $\cdots$ & $\cdots$ & & & & & & & & & $\cdots$ \\
\hline versa Conrad. & & $\cdots$ & & & & . & $\cdots$ & {$[\cdots . .$.} & $\cdots$ & $\ldots .$. & & $\ldots$ & & & & & $\cdots$ & 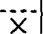 & $x$ & & & $\because$ & & & & & & $\ldots$ \\
\hline & $\begin{array}{l}x \\
x\end{array}$ & $\ldots$ & $\ldots$ & & $\ldots$ & & 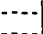 & & & 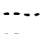 & & & & & & & & & & & & & & & & & & $\cdots$ \\
\hline & & & & & $\because$ & & & & & $\cdots$ & & & & & $\cdots$ & & & $\cdots$ & & & & & & & & & & $\cdots$ \\
\hline & $x$ & $\cdots$ & $\cdots$ & $\cdots$ & $x$ & $\cdots$ & -. & $\cdots$ & $\cdots$ & & & & & & & & - & & & & & $\cdots$ & & & & & $\cdots$ & $\cdots$ \\
\hline ris & $\hat{x}$ & $\cdots$ & & & $\cdots$ & & & & & & & & & & & & & & & & & & & & & & & \\
\hline & $|x|$ & & & & & & & & & & & & & & & & & & & & & & & & & & & $\cdots$ \\
\hline & $\hat{x}$ & {$\left[\begin{array}{c}\cdots . . \\
\cdots\end{array}\right.$} & $\cdots$ & & $\cdots+2>+3$ & $\cdots$ & $\cdots$ & $x !$ & & & & & & & & & & & & & & $\cdots$ & & & & & & \\
\hline & $\hat{x}$ & & & & & & & & & & & & & & & & & & & & & & & & & & & \\
\hline & & & & & & & & & & & & & & & & & & & & & & & & & & & & \\
\hline & $x$ & $\cdots$ & $\cdots$ & $\cdots-1$ & $x$ & $\cdots$ & $\cdots$ & $\cdots$ & $\cdots$ & $\cdots$ & & $\cdots$ & $\cdots$ & & & & & & & & & & & & & & & \\
\hline & & & & & 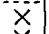 & $\cdots$ & $\cdots$ & & & & & & & & & & & & & & & & & & & & & \\
\hline & $\begin{array}{l}x \\
x\end{array} \mid$ & $\cdots$ & $\cdots$ & $\cdots$ & $x$ & & & & & m & & & & & & & & & & 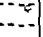 & $\cdots$ & & & & & & & \\
\hline & $\hat{x}$ & & & & $\cdots$ & $\cdots$ & $\cdots$ & & & $\cdots$ & & & $\cdots$ & & & & & & & & $\cdots$ & & & 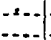 & & $\ldots$ & $\cdots$ & \\
\hline (2n..................... & $\mid \begin{array}{l}x \\
x\end{array}$ & & & - & $x$ & & & & & - & & & & & & & & & & & & & & & & & & \\
\hline & & & & & $\hat{x}$ & & & & & & & -1 & & & & & & & & & & & & & & & & \\
\hline & & $\ldots$ & & $\ldots$ & $x$ & & $\cdots$ & & & & & & & & & & $\ldots$ & & & & & $\ldots$ & & $\cdots$ & $\ldots$ & $\cdots$ & $\ldots . .$. & $\ldots .$. \\
\hline & $x$ & $\cdots$ & & & $x$ & & $\cdots$ & & & & & & & & & & $\ldots$ & & & & & $\cdots$ & & 1 & & I & W & $\ldots$ \\
\hline$\cdots$ & & & & & $\left|\begin{array}{l}x \\
x\end{array}\right|$ & & & & & & & & & & & & & & & & & & & & & & & $\ldots$ \\
\hline & & & & $\ldots$ & $\hat{x}$ & & & & & & & & & & & & & & & & & & & & & & & \\
\hline & $x$ & & & & & $\cdots$ & & & & & & & & & & & & & & & & & & & & & $\ldots$ & \\
\hline bry & $\hat{\theta}$ & & & & & & & & & & & & & & & & & & & & & & & & & & & \\
\hline & $\tilde{x}$ & $\cdots+2+2+3$ & $\cdots$ & $\cdots-1$ & $x$ & 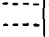 & $\cdots$ & & & & & & & & & & & & & & & -.. & & $\ldots . .$. & $\ldots . .$. & $\ddot{x}$ & & \\
\hline & $\begin{array}{l}x \\
x\end{array}$ & & & $\cdots$ & & & & & & & & & & & & & & & & & & & & & & $\cdots$ & $\cdots$ & \\
\hline ….... & $|x|$ & & & & & & & & & & & & & & & & & & & & & & & & & & & \\
\hline & & & 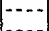 & I & $\begin{array}{l}x \\
x\end{array}$ & & & & & & & & & & & & & & & & & & & $\ldots$ & & $\ldots$ & & \\
\hline$T$ & $\hat{x}$ & $\cdots-1$ & & $\cdots \cdot-1$ & $x$ & & & & $\cdots$ & & & & & & & & & & & & & & & 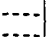 & & & & \\
\hline & & & & - & $x$ & & & $\cdots$ & -. & & & & & & & & & & & & & & & & & $\ldots$ & & \\
\hline & $x$ & & $x$ & & $\mid \begin{array}{l}x \\
x\end{array}$ & & & & & & & & & & & & & & & & & & & & & & & \\
\hline & $x$ & & & & & & & & & & & & & & & & & & & & & & & & & & & \\
\hline & $\hat{x}$ & & & & & & & & & & & & & & & & & & & & & & & & & & & \\
\hline Lyell and & $x \mid$ & $x$ & & $x$ & & & & & & & & & & & & & & & & & & & & & & & & \\
\hline & $\bar{x}$ & & & & & & & & & & & & & & & & & & $x$ & & & & & & & & & \\
\hline & & & & & & & & & & & & & & & & & & & & & & & & & & & & \\
\hline
\end{tabular}




\section{ANALYSIS OF THE TRENT FAUNA}

Although the Trent formation is centrally located on the eastern Coastal Plain of the United States, its fauna has, until the present study, received no attention whatever from the systematic paleontologist. The formation consists chiefly of light-colored calcareous marl, either loose or consolidated into a hard, impure limestone (commonly called buhrstone), and is made up almost entirely of casts of marine shells. The identification of such material is practically impossible unless better material of the same age and from the same region is available for comparison. The discovery of a bed of well-preserved Trent fossils near Silverdale, in Onslow County, has made possible a critical study of the fauna. As yet only a small collection has been made from this locality, but it is sufficient to show the presence of a fairly large and varied molluscan assemblage. The present study is confined to the larger forms of the fauna, and the following analysis is based entirely on this element.

A total of 26 species of Mollusca from the Trent marl have been studied and described. These are segregated into 21 genera and 17 families. The Pelecypoda are represented by 13 genera and 10 families; the Gastropoda by 8 genera and 7 families. Of this assemblage 15 species and 1 variety are new; 3 species are undeterminable; and 7 are referred to species previously described, including two that came originally from the Trent marl and have not been recognized elsewhere. It is therefore apparent that the Trent fauna is essentially new.

Two orders of the class Pelecypoda are present in the forms studied-the Prionodesmacea, represented by 6 species, and the Teleodesmacea, represented by 12 species. Among the Prionodesmacea the Arcidae are the most numerous. They include two genera, Arca and Glycymeris, both of which are fairly abundant in individuals. The Pectinidae and the Spondylidae have relatively few representatives. The Teleodesmacea fall into 7 families, of which the Veneridae are by far the most significant. The genera Venus and Macracallista, because of their unusual form, widespread occurrence, and abundant individual development, are the most diagnostic elements of the fauna. The species of these genera are rather small; those of Venus especially appear to be stunted. This fact suggests peculiar ecologic conditions or excessive salinity of the sea in which these forms flourished. The family Crassatellitidae is represented by one genus, Crassatellites, which occurs in large numbers of individuals. The other families of Teleodesmacea, including the Astartidae, Carditidae, Lucinidae, Cardiidae, and Saxicavidae, are very interesting groups, but each is represented by only one genus and these forms are not abundant.
The Gastropoda of the Trentifauna that have been considered in this study belong, without exception, to the order Ctenobranchiata. The predominant family of this assemblage is the Turritellidae, which is represented by the single species Turritella fuerta Kellum, one of the commonest species in the Trent fauna. This species is variable in form, and the variations follow certain definite lines, which find a parallel development in the Turritellas of the "silex beds" of the Tampa formation of Florida. The Volutidae are next in numbers and are represented by two genera, Lyria and Scaphella, of which the latter is unusually abundant in individuals. The family Capulidae is of little diagnostic importance, though it is very common at every Trent locality. It includes the well-known species Calyptraea trochiformis Lamarck. The families Conidae and Buccinidae are of especial interest because of their large numbers of individuals. The genus Busycon attains the largest size, with the possible exception of an undescribed Ostrea, of all the forms in the fauna. The Naticidae and the Olividae are minor elements of the Trent. assemblage.

The part of the Trent fauna which has been covered in this paper is an interesting association of forms: related to known species from widely separated horizons. These affinities range from the Vicksburg Oligocene to the upper Miocene. The true position of the Trent is somewhere between these extremities. About 25 per cent of the fauna has its closest affinity with species of the upper Miocene, 45 per cent with forms in the lower Miocene, and 30 per cent with Oligocene species. Although the predominance of relationship to lower Miocene forms is not overwhelming, the fact that the percentage of affinities. in the upper Miocene and in the Oligocene is nearly equal indicates rather conclusively that the Trent fauna is of lower Miocene age. Another fact that: strongly confirms this determination is the presence of true Venus in the fauna. This genus as limited by Lamarck originated and reached its maximum development during the Miocene epoch. Two species of Venus occur in the Trent and are among the most abundant forms. They find their closest affinity in $V$. halidona Dall, from the Tampa formation of the lower Miocene in Florida.

The accompanying table shows the geologic range of the form closest to each Trent species. Such a system of comparison may lead to very wrong conclusions, because the degree of relationship between the species and its analogue is different in every case. Some genera, because of their long range or simple form, are of less value for correlation than others. To the more diagnostic genera should therefore be given greatest weight in determining the age of the, fauna. 
Geologic range of forms comparable with Trent species

\begin{tabular}{|c|c|c|}
\hline Trent species & Closest affinity & Range of closest affinity \\
\hline 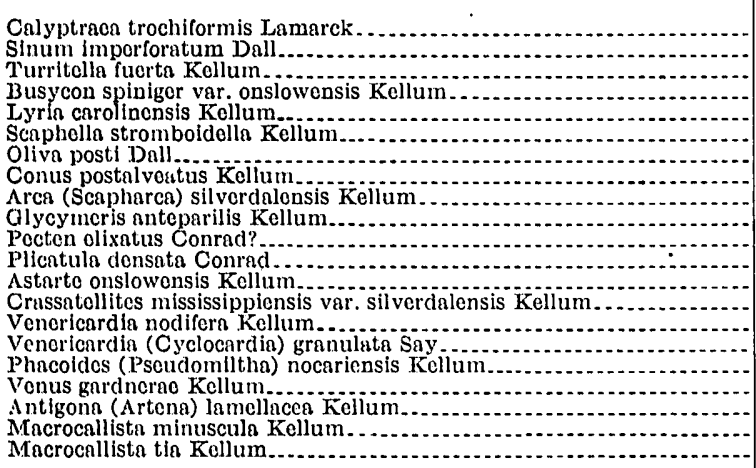 & 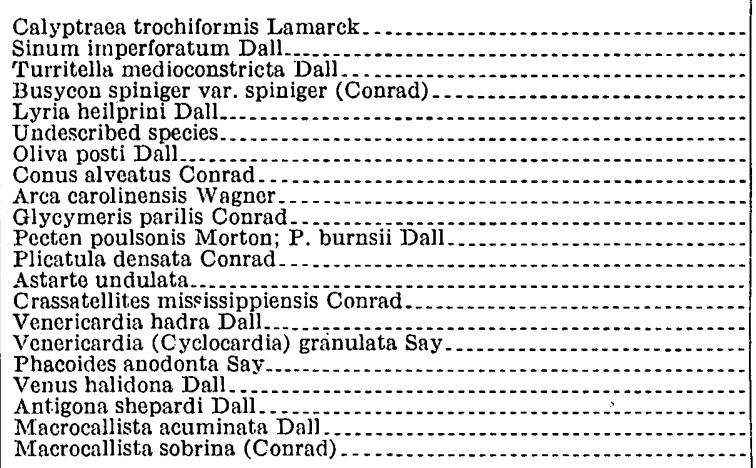 & $\begin{array}{l}\text { Claiborne to Duplin. } \\
\text { Do. } \\
\text { Tampa. } \\
\text { Vicksburg (Red Bluff) } \\
\text { Tampa. } \\
\text { Shoal River. } \\
\text { Tampa. } \\
\text { Vicksburg. } \\
\text { Duplin. } \\
\text { Calvert. } \\
\text { Vicksburg; Chipola. } \\
\text { Vicksburg to Bowden. } \\
\text { Duplin. } \\
\text { Vicksburg. } \\
\text { Chipola. } \\
\text { Calvert to Pliocene. } \\
\text { Do. } \\
\text { Tampa. } \\
\text { Do. } \\
\text { Tampa and Chipola. } \\
\text { Vicksburg. }\end{array}$ \\
\hline
\end{tabular}

The standard lower Miocene section of the Coastal Plain comprises four horizons, which, beginning with the lowest, are represented by the Tampa, Chipola, Oak Grove, and Shoal River formations of Florida. The fauna of the Tampa formation was monographed by William Healey Dall in $1915 .^{24} \mathrm{He}$ correlated it with the Lower Aquitanian of Europe, which at that time he considered Oligocene.

The Aquitanian, however, is now regarded as lower Miocene. The faunas of the three higher formations are described by Julia Gardner in Professional Paper 142, now in press. They are regarded as separated from the Tampa by a conspicuous interval but are relatively close to one another in point of time. North of Florida the only lower Miocene formation that has been recognized on the east coast is the Marks Head marl of Georgia. When the fauna was first studied by $\mathrm{T}$. Wayland Vaughan ${ }^{25}$ this formation was correlated approximately with the Calvert of Maryland. It is now, however, considered to be of the same age as the Chipola formation of Florida. ${ }^{26}$

Three of the Trent species have been specifically identified with forms occurring in the "silex beds" of the Tampa formation of Florida, four others have their closest affinity in the Tampa, and one is closely allied to a species occurring both in the Tampa and the Chipola. There is only one Trent species, Venericardia nodifera Kellum, which has its nearest relative confined to the Chipola, and the Tampa form V. serricosta Heilprin is almost as close as the Chipola affinity. Pecten elixatus Conrad is related to $P$. poulsoni, a Vicksburg species, and $P$. burnsii, a Chipola species. One Trent species, Scaphella stromboidella Kellum, has its closest affinity in the Shoal River, and none is nearly related to Oak Grove species. It is obvious, therefore, that of the 45 per cent whose closest described species are in the lower Miocene, the large

24 Dall, W. H., A monograph of the molluscan fauna of the Orthaulax pugnax zone of the Oligocene of Tampa, Fla.: U. S. Nat. Mus. Bull. 90, 1915.

ss Vaughan, T. W., Science, new ser., vol. 31, pp. 833-834, 1910.

30. Gardner, Julla, The detection of the Ohipola fauna in the Marks Head mari: Washington Acad. Sci. Jour., vol. 15, pp. 264-268, 1925. majority are related to Tampa forms. The conclusion is therefore reached that the Trent marl is of approximately the same age as the "silex beds" of the Tampa of Florida. The collection of more material from this horizon and the study of the microscopic element of the fauna may show the Trent to be somewhat older or younger than the Tampa, but the evidence presented by the fraction of the fauna studied indicates the Tampa as the closest known formation.

\section{FIELD STATIONS OF THE TRENT MARL}

The fossils collected from the Trent marl are listed in the table on page 14. Notes concerning the field stations are given below. (See fig. 1.)

10654. In Jacksonville, Onslow County, at east end of wagon bridge over New River. The eastern abutment of the bridge is an outcrop of limestone. Large masses of the rock excavated from the road are piled by the roadside. The exposure is a hard gray impure limestone made up entirely of casts of bivalves from which most of the shelly material has been dissolved.

10655. Half a mile southeast of Silverdale, Onslow County, on farm of John Gillette, on left side of Webbs Creek. Yellow rotten-shell marl is exposed over a small area in pits about 6 feet deep. The shells are white and lie in a matrix of yellow earthy sand. For the most part the shells are weathered and broken, but many individuals are in a state of perfect preservation.

10656. Quarry of Atlantic Marl \& Lime Fertilizer Co. at Scott Landing, on left side of Trent River about 4 miles downstream from Polloksville, Jones County. An exposure of hard limestone about 3 feet thick crops out along the bank for a distance of 100 feet. About 100 yards back from the river limestone and marl have been quarried to a depth of 25 feet over an area of several acres. The following section is exposed in the quarry:

Pleistocene: Unconsolidated white or light-yellow Feet sand . . . . . . Miocene (?): Ground-shell marl with little sand ..... $\quad 12-15$ Lower Miocene (Trent marl): Hard yellow impure limestone, made up entirely of casts of marine shells............ 6-10

Right bank of Trent River about 6 miles below Polloksville. This station was visited by G. D. Harris, who reports fossils 
Mollusks from the Trent marl

\begin{tabular}{|c|c|c|c|c|c|c|c|}
\hline . & 10654 & 10655 & 10656 & $\begin{array}{c}\text { Har- } \\
\text { ris }\end{array}$ & 7796 & 10657 & 7798 \\
\hline alyptraea trochiformis Lamarck & & 人 & & & & & \\
\hline - & & x & & & & & \\
\hline Turritella fuerta Kellum & & $x$ & & & & & \\
\hline Busycon spiniger var. onslowensis Kellum & & $x$ & & & & & \\
\hline Lyria carolinensis Kellum & & $x$ & & & & & \\
\hline Scaphella stromboidella Kellum & & $x$ & & & & & \\
\hline Oliva posti Dall & & $x$ & & - & & & \\
\hline Conus postalveatus Kellum & & 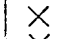 & - & -- - & & & - \\
\hline Arca (Scapharca) silverdalensis Kellum & & X & & $\ldots$ & & - & - \\
\hline Glycymeris anteparilis Kellum & & X & & & & & - \\
\hline Glycymeris sp & & $-\ldots$ & x & & & & 1-- \\
\hline Pecten elixatus Conrad? & & -1 & & X & & & - \\
\hline Isis Harris. & & & & $x$ & & & \\
\hline Plicatula densata Conrad & & X & & & & & \\
\hline sis Kellum. & & $x$ & & & & & \\
\hline ississippiensis var. silverdalensis Kellum & & $x$ & & -- & & & \\
\hline Venericardia nodifera Kellum & & $x$ & & & & & \\
\hline Venericardia (Cyclocardia) granulata Say & & $x$ & & & & & \\
\hline Phacoides (Pseudomiltha) nocariensis Kellum & & $x$ & & & & & \\
\hline - & & & & & & & \\
\hline 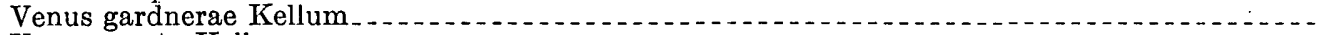 & & $x$ & & -- & X & & - \\
\hline Venus erecta Kellum & & $x$ & --- & - & 入 & & - \\
\hline Antigona (Artena) lamellacea Kellum. & & X & & & & & \\
\hline Macrocallista minuscula Kellum $\ldots$ & $x$ & X & $x$ & . & & $x$ & $x$ \\
\hline Macrocallista tia Kellum & --- & $x$ & & --- & & --- & -- \\
\hline - & $x$ & -- & X & $-\cdots$ & $x$ & & - \\
\hline
\end{tabular}

collected from a "marly bed $* * *$ in the so-called Trent formation."

7796. White Rock Landing, left bank of Trent River about 12 or 13 miles above New Bern. This station was visited by B. L. Miller, who describes the exposure as follows: "The Eocene limestone appears here and rises about 15 feet above the water. Casts of fossils are numerous. The Eocene is overlain by about 15 feet of Pleistocene strata consisting principally of yellowish-brown loamy clay, containing some small pebbles The same stratum of Eocene rock is exposed at many other places along Trent River in the same vicinity." Casts collected from the limestone at this locality by Miller have been identified as Trent fossils. The exposure is therefore low er Miocene in age, instead of Eocene.

1065\%. Rock Spring, on right bank of Trent Riv er 31/2 miles upstream from New Bern, on farm of James N. Smith. Small patches of limestone, about 2 feet thick, crop out along the bank for a distance of 100 feet. The limestone is hard and gray and consists chiefly of casts of marine bivalves.

7798. Spring Garden Landing, right bank of Neuse River $31 / 2$ miles northeast of Jasper, Craven County. This station was visited by B. L. Miller, who describes the exposure as follows: "A hard white Eocene limestone rises in the low river bank about $31 / 2$ feet above the level of the water in the river. The limestone contains many fossil casts; the shell substance is entirely gone, and the cavities are usually filled with calcite crystals. In places the cavities have not been filled. This rock has been used for buhrstones. The fossils present, though numerous are not varied. Above the rock occurs thinly laminated drab clay and gray sand of Pleistocene age, with an average thickness of about 10 feet. In the river bank the Eocene is well exposed."

\section{SYSTEMATIC PALEONTOLOGY OF THE CASTLE HAYNE MARL \\ ECHINODERMATA}

Nearly all the Tertiary Echinodermata of North Carolina have been brought together and described in Monograph 54 of the United States Geological Survey. The descriptions and figures of this work are very complete and perfect. In view of the accessibility of the monograph it does not seem worth while to repeat the descriptions and figures here. The various described species of echinoderms occurring in the Eocene of North Carolina are therefore simply listed systematically, together with the localities from which they have been collected. In addition two new species and a new variety have been described. The species listed are from the Castle Hayne marl, which is of Jackson age (upper Eocene).

\section{Class ECHINOIDEA}

Subclass REGULARIA ENDOBRANCHIATA

Order CIDAROIDEA

Family CIDARIDAE

Genus CIDARIS Leske

Cidaris pratti Clark

Locality: Wilmington, New Hanover County, N. C.

Subclass IRREGULARIA

Order GNATHOSTOMATA

Suborder GLYPEASTRINA

Family FIBULARIDAE

Genus ECHINocyamus Phelum

Echinocyamus parvus Emmons

Localities: Craven County, N. C.; 10 miles north of Jacksonville, Onslow County, N. C.

Clark and Twitchell give the horizon of this species as probably the Trent marl. The writer has found it in Onslow County associated with typical Castle Hayne forms and therefore considers it as belonging to that horizon. 


\section{Family SCUTELLIDAE}

Genus PERIARCHUS Conrad

Periarchus lyelli (Conrad)

Localities: Castle Hayne and Wilmington, New Hanover County; old Rocky Point, Moors Creek 3 miles northeast of Maple Hill, and Northeast Cape Fear River $31 / 2$ miles above Castle Hayne Bridge, Pender County; 2 miles south of Magnolia, Duplin County; Little Chinquapin Creek, half a mile north of Winsatt, Jones County, N. C.

\section{Order ATELOSTOMATA}

Suborder ASTERNATA.

Family CASSIDULIDAE

Genus CASSIDULUS Lamarck

Cassidulus (Rhynchopygus) raveneli Twitchell

Localities: Wilmington, New Hanover County; old Rocky Point, Pender County, N. C.

\section{Cassidulus (Pygorhynchus) carolinensis Twitchell}

Localities: Wilmington (and Castle Hayne), New Hanover County; old Rocky Point, Pender County, N.C.

Cassidulus (Pygorhynchus) carolinensis var. cravenensis Kellum, n. var.

Plate I, Figures 1-3

Test essentially the same as $C$. carolinensis Twitchell but distinguished by a slightly more tumid upper surface, which is about equally elevated anteriorly and posteriorly. Ventral surface slightly concave, with posterior margin truncated by three nearly straight lines, giving it an angulated outline. Peristome somewhat variable in shape, pentagonal, frequently compressed laterally.

This variety occurs at the same horizon as $C$. carolinensis Twitchell but is most abundantly developed in Craven County, about 80 miles northeast of the type locality for that species. The type specimen was collected 3 miles east of Quinerly, Pitt County, N. C.

\section{Cassidulus (Pygorhynchus) berryi Kellum, n. sp.}

Plate I, Figures 4-7

Test large, subquadrate to ovoid, depressed; upper surface convex, declining from apex nearly equally on all sides. A slight tumidity exists along the medial line above the periproct. Apical system at the apex, slightly eccentric anteriorly, large; ambulacral areas of nearly equal length, large, broad, petaloid, and extending almost to the margin of the upper surface; poriferous zones wide, slightly depressed; pores oval, outer row more elongate; pairs of pores conjugate; interporiferous areas slightly tumid. Under surface longitudinally concave; peristome rather large, pentagonal, transversely elongate, excentric anteriorly, more so than the apical system; peristome surrounded by a large, well-defined floscelle, with prominent bourrelets. The surface of the test is closely set with small scrobiculate tubercles, which increase in size on the under surface except along a rather narrow, longitudinal median area which is finely pitted. The periproct is submarginal on the upper surface, but its size and shape are unknown. Dimensions of figured type: Length, 60 millimeters; width, 57 millimeters, thickness, 28 millimeters.

Cassidulus berryi is not likely to be confused with any other Eocene species from the east coast. It is strikingly similar to $C$. alabamiensis Twitchell, from the Vicksburg group (Oligocene) of Alabama, from which it is distinguished by its less pronounced quadrate form, its wider and slightly more tumid interporiferous zone of the ambulacral areas, and its somewhat narrower poriferous zones.

Locality: 2 miles north of Jacksonville, Onslow County, N. C.

Geologic horizon: Castle Hayne marl, of Jackson Eocene age.

\section{Genus ECHINOLAMPAS Gray}

\section{Echinolampas appendiculatus Emmons}

Localities: Newbern, Craven County (Emmons); Wilmington, New Hanover County; old Rocky Point; and Moors Creek, 2 miles west of Angola, Pender County, N. C.

\section{Suborder STERNATA \\ Family SPATANGIDAE \\ Genus HEMIPATAGUS Desor \\ Hemipatagus subrostratus Clark}

Locality: Wilmington, New Hanover County, N. C. Genus IINTHIA Merian

Linthia wilmingtonensis Clark

Locality: Wilmington, New Hanover County, N. C. Linthia hanoverensis Kellum, n. sp.

Plate I, Figures 8-9

Test of medium size, ovate, gibbous above, slightly convex below; apical system excentric, slightly anterior to the apex; ambulacral areas narrow, depressed, with large oval pores in almost parallel rows; anterolateral paired ambulacra long, reaching almost to the margin, posterolateral pair short; groove of the single anterior ambulacrum slightly indents the margin; interambulacral areas inflated; peristome well forward; periproct not shown on type specimen. Surface of test closely set with small tubercles, which are larger on the under surface. Length, 28 millimeters; breadth, 26.5 millimeters; height, 19 millimeters.

Lọcality: Wilmington, New Hanover County, N. C.

Geologic horizon: Castle Hayne marl, of Jackson Eocene age. 
Linthia hanoverensis is distinguished from $L$. witmingtonensis Clark, which occurs at the same locality, by its more regularly inflated upper surface, the shallower depressions of the ambulacral areas, and the less pronounced notch in the anterior margin.

\section{Genus eUPatagus Agassiz}

Eupatagus carolinensis Clark

Locality: Wilmington, New Hanover County, N. C. Genus MACROPNEUSTES Agassiz

Macropneustes carolinensis Clark

Locality: Wilmington, New Hanover County, N. C. Phylum MOLLUSCA

Class PELECYPODA

Order PRIONODESMACEA

Superfamily ARACEA

Family ARCIDAE

Subfamily ARCINAE

Genus ARCA (Linnaeus) Lamarck

Arca sp. $a$

Plate I, Figures 13-1.4

Cast profoundly inflated, inequilateral, ranging in length from 20 to 100 millimeters. Beaks strongly anterior, low, close; anterior and posterior margins rounded and uncrenulated; hinge line of moderate length, slightly curved, with about 30 teeth in two series meeting below the beaks, posterior series small and vertical at the umbo, becoming larger and oblique distally, anterior series of about seven larger teeth. Surface of cast shows indistinct radial lines and concentric lines of growth rather strongly developed. Exterior sculpture unknown. Dimensions of large cast: Length, 60 millimeters; height, 35 millimeters; depth of right valve, 16 millimeters; length of hinge line, 40 millimeters.

This form is similar to Arca millifila Dall, from the Pliocene of Shell Creek, Fla. The hinge line of $A$. millifila is more extended anterior to the beaks, with the teeth in one continuous series. It is also characterized by a more definite posterior ridge on the internal cast.

Localities: Wilmington, New Hanover County; old Rocky Point, Pender County, N. C.

Geologic horizon: Castle Hayne marl, of Jackson Eocene age.

\section{Arca sp. $b$}

Platè I, Figure 15

Cast very small, subrhomboidal, inequilateral, inflated. Beaks distant and situated well forward, in the anterior fifth of shell. Anterior and posterior margins nearly straight and inclined to the hinge line; basal margin slightly curved; hinge line long, straight, with teeth vertical beneath the beaks, becoming inclined distally; anterior and posterior ridges (of internal cast) very prominent, extending from the beak to the extremities of the basal margin; adductor muscle scars very distinct and large, covering most of the space between the ridges and the hinge line and extending from the beaks almost to the anterior and posterior margins. Surface of cast between the ridges shows coarse radial sculpture and concentric lines of growth. Length, 11 millimeters; height, 5.5 millimeters; depth of both valves together, 4.5 millimeters.

This species is not rare in the Eocene marls at Wilmington, but it has been found there only as casts. It resembles Arca reticulata Gmelin, from the "silex beds" of the Tampa formation of Florida, but has the beaks more distant.

Locality: Wilmington, New Hanover County, N. C.

Geologic horizon: Castle Hayne marl, of Jackson Eocene age.

Arca sp. $c$

Plate I, Figures 10-12

Arca cancellata Tuomey, Acad. Nat. Sci. Philadelphia Proc., vol. 6 , p. 194,1852 .

Dall, Wagner Free Inst. Sci. Trans., vol. 4, p. 658, 1898.

Tuomey's description of this species is as follows:

Shell thin, very inequilateral, cancellated by radiating lines and approximating transverse lines; umbones prominent; beaks close; hinge line slightly curved; posterior margin rounded, compressed; anterior margin much contracted. Dimensions: Length, 2.5 inches; breadth, 3.5 inches.

Regarding the validity of this species, Dall says: "A. cancellata Tuomey, briefly described and unfigured, from the Eocene of North Carolina, in 1854, is not A. cancellata Gmelin, 1792, or Phillips, 1829, and should be expunged from our lists."

There is an Arca occurring abundantly in the Eocene at Wilmington which seems to fulfill the brief description of what Tuomey called $A$. cancellata. Usually it is much smaller than the dimensions given by Tuomey, but some individuals reach that size. It is preserved chiefly as internal casts, but external casts are rarely found also.

Cast elongate oval, inequilateral, with beaks strongly anterior; anterior margin rounded and somewhat truncate; basal margin in young specimens straight, in adult forms modified by a subcentral sinus; posterior margin broadly rounded. Cast somewhat inflated anteriorly and flattening toward the posterior end, with a broad subcentral sinus, passing from the beak to the basal margin in adult specimens. Hinge line long; very slightly curved, with 25 to 30 teeth that are small and vertical beneath the umbone and become larger and inclined distally. Surface of internal cast reflects' radial and concentric sculpture. External 
sculpture of the shell coarsely cancellate. Dimensions of large cast, anterior and posterior margins broken: Length, 75 millimeters; height, 44 millimeters; depth of right valve, 19 millimeters. Dimensions of small perfect cast: Length, 33 millimeters; height, 19 millimeters; depth of both valves together, 13 millimeters.

Locality: Wilmington, New Hanover County, N. C.

This species is indistinguishable from a large Arca found in the Ocala limestone at Normans Ferry, Flint River, Ga. This also is preserved only as a cast and has not been identified. The horizon from which it comes is Jackson Eocene.

Young specimens are very similar in shape to $A$. rhomboidella Lea, from the Gosport sand of the Claiborne group of Alabama. Internal casts of $A$. rhomboidella, however, have a more definite posterior ridge, a less inflated umbonal region, and as a rule a marginal crenulation.

\section{Superfamily OSTRACEA}

\section{Family OSTREIDAE}

\section{Genus OSTREA (Linné) Lamarck}

\section{Ostrea alabamiensis subsp. georgiana Conrad}

Ostrea georgiana Conrad, Acad. Nat. Sci. Philadelphia Jour.. 1st ser., vol. 7 , p. $156,1834$.

Dana, Manual of geology, 1st ed., p. 519, fig. 811, 1863.

Dall, Wagner Free Inst. Sci. Trans., vol. 3, pt. 4, p. 683, 1895.

Ostrea titan Conrad, Acad. Nat. Sci. Philadelphia Proc., 1st ser., vol. 6, p. 199, 1854; U. S. Pacific R. R. Expl., vol. 6 , pt. 2, p. 72, pl. 4, fig. 17a; pl. 5, fig. 17a, 1857.

Ostrea contracta Conrad, U. S. and Mexican Boundary Survey Rept., vol. 1, pt. 2, p. 160, pl. 18, figs. 1 a-d, 1857.

Ostrea alabamensis Conrad var. contracta Harris, Bull. Am. Paleontology, vol. 6, p. 9, pls. 3, 4, pl. 5, fig. 2, 1919.

The original description of Ostrea georgiana by Conrad in 1834 is as follows:

Shell thick, elongated, straight; hinge much produced; upper valve nearly flat. Localities: Orangeburgh, S. C., Shell Bluff and near Milledgeville, Ga. This species is found 22 inches in length and is remarkable for the length and depth of the cardinal fosset.

Dall, in discussing this species, says:

The typical $O$. georgiana are the enormous senile specimens with shells ranging to 2 feet long and 3 or 4 inches thick. The young and really more normal specimens have been overlooked, though much more abundant, or referred to other species, chiefly 0 . virginica, from which they differ by their more elongated, usually straight, deeply excavated cardinal area and the absence of ribbing on the lower valve in most specimens.

0 . georgiana is very abundant at one locality in North Carolina. At Polloksville, on Trent River in Jones County, it forms a bed 15 feet thick. For the most part the shells are large and thick, but they are so weathered that it is difficult to procure a complete specimen. Young individuals retain perfectly the fine epidermal radial sculpture, which, according to Miss Gardner, ${ }^{27}$ is the one constant feature of $O$. georgiana and one identical with that of $O$. alabamensis.

Locality: Polloksville, Jones County, N. C.

Geologic horizon: Castle Hayne marl, of Jackson Eocene age.

\section{Ostrea trigonalis Conrad}

Lesueur, Walnut Hills fossils, pl. 4, fig. 17, pl. 5, fig. 1, 1829 (not named or described).

Ostrea trigonalis Conrad, in Wailes, Report on the agriculture and geology of Mississippi, p. 289, pl. 14, fig. 10 (bad), 1854.

Conrad, Acad. Nat. Sci. Philadelphia Proc., vol. 7, p. 259, 1855.

8Ostrea subj ecta Ccnrad, Cnited States Facific R. R. Expl., vol 7, pt. 1, p. 193, pl. 2, fig. 3, 1857 (young shell).

POstrea attwoodii Gabb, Paleontology of California, vol. 2, pp. 33, 106, pl. 10, fig. 58b, 1869.

Conrad's original description of this shell was very brief :

Triangular, flat, surface irregular, with some indistinct radiating lines; muscular impression obliquely suboval, situated nearer the summit than the base; margin somewhat ascending, submargin carinated.

Dall gives the range of $O$. trigonalis from Jacksonian Eocene to Pliocene. His discussion of the species follows :

The original figure of Conrad is very poor. The species is widespread and recognized by its flat upper valve, few-ribbed lower valve, straight hinge line, flat hinge area, with excavated central channel and the peculiar vermicular sculpture of the submargin on each side near the hinge line. It is not improbable that $O$. percrassa Conrad is a peculiar local race of this species and that $O$. mortoni Gabb and $O$. vicksburgensis Conrad are young pebble-grown shells of the same species as the large, well-grown specimens which I regard as normal trigonalis. The differences are, however, so marked that it is probably best to keep them separate for the present, until more is known. O. subtrigonalis of Evans and Shumard is a Cretaceous species. Varieties of $O$. compressirostra approach very closely to this species.

Localities: Wilmington, New Hanover County; Old Rocky Point; Castle Hayne; 2 miles west of Angola; and Northeast Cape Fear River $31 / 2$ miles above Castle Hayne Bridge, Pender County; 2 miles south of Mangolia and 6 miles west of Pink Hill, Duplin County; near Broadhurst Bridge, Neuse River, Wayne County; Polloksville and half a mile northwest of Winsatt, Jones County, N. C.

Geologic horizon: Castle Hayne marl, of Jackson Eocene age.

\section{Ostrea sellaeformis Conrad}

Ostrea sellaeformis Conrad, Fossil shells of the Tertiary formations, p. 27, pl. 13, fig. 2, 1832 (upper valve).

Ostrea radians Conrad, op. cit., pl. 13, fig. 1 (lower valve).

Ostrea divaricata Lea, Contributions to geology, p. 91, pl. 3 , fig. 70, 1833.

Ostrea semilunata Lea, op. cit., p. 90, pl. 3, fig. 69, fide Conrad.

27 Gardner, Julia, U. S. Geol. Survey Prof. Paper 131, p. 110, 1923 
Ostrea falciformis Conrad, Acad. Nat. Sci. Philadelphia Proc. for 1863, p. 291; Am. Jour. Conchology, vol. 1, p. 140, pl. 11, fig. 1, 1865.

Ostrea stellaeformis Conrad, Am. Jour. Conchology, vol. 1, p. 15, 1865 (typographic error).

Ostrea lingua-felis Whitfield, Brachiopoda and Lamellibranchiata of the Raritan clays, p. 223, pl. 29, fig. 1, 1885.

Ostrea glauconoides Whitfield, op. cit., pl. 29, fig. 2.

The original description of Ostrea sellaeformis from Claiborne, Ala., is as follows:

Oblong, convex, thick and ponderous, lobed; one side of the larger valve profoundly sinuous and the opposite side gibbous; smaller valve sinuous and little convex; dorsal margin long and slightly arched, with both extremities obtusely rounded. This singular shell does not vary greatly in its outline and is very unlike any other species of this country with which we are acquainted. It is of ten extremely thick and ponderous.

The specimens of Ostrea sellaeformis occurring in the Eocene beds of North Carolina are all small forms and, for the most part, belong to the varieties divaricata Lea and rugifera Dall. O.divaricata, which Dall considers a variety of $O$. sellaeformis, was briefly described by Lea as follows:

Shell semilunate, somewhat convex, subangular at dorsal margin and recurved, rounded at basal margin, furnished with divaricate ribs over the whole surface; margin crenulate, raised before the beak. *** Length, $1: 5$; breadth, 0.8 inch.

\section{Dall says of the variety rugifera:}

Shell rather thin, irregular, coarsely ribbed, more or less imbricated, margin plicate, form tending to ovate or rounded.

Regarding the diverse forms of $O$. sellaeformis, Dall says:

The whole series seems to be a continuous development from the lower Eocene divaricata to the present form. The typical sellaeformis appears to be a merely local development, probably from peculiarity of situs of the individuals concerned. It was some time before I could bring myself to unite some of the very distinct looking forms which have been called divaricata with the sellaeformis type, but careful study of a large series has convinced me that this is the proper course.

Localities: Wilmington, New Hanover County; Old Rocky Point, Pender County; Biddle Landing, Trent River, Craven County; 3 miles east of Quinerly, Pitt County; 21/2 miles west of Dover, Jones County; $11 / 2$ miles northeast of Rose Hill, and 5 miles west of Pink Hill, Duplin County, N. C.

Geologic horizon: Castle Hayne marl, of Jackson Eocene age.

\section{Ostrea falco Dall?}

Ostrea falco Dall, U. S. Nat. Mus. Proc., vol. 18, p. 22, 1895; Wagner Free Inst. Sci. Trans., vol. 3, pt. 4, pl. 30, figs. 4, 11, 1898 .

Dall describes Ostrea falco as follows:

Shell thin, the fixed valve thin, irregular, cellular or deep, adherent over most of its surface, having a deep umbonal cavity under the cardinal border; the exterior rude, not perceptibly sculptured; free valve flat, thin, with a very acute, usually curved flat beak; the interior margins with a row of strong pustules extending over two-thirds the length of valve from the beak and fitting into corresponding pits in the fixed valve; adductor scar small, rather laterally situated; the valve as a whole more or less arcuate; exterior showing remains of a purplish tint, with low, numerous, even, concentric imbrications, each of which is finely radially threaded, with rather wider interspaces between the threads; general outline flabelliform, wide, and rounded in front and acutely pointed behind. Height of a medium-sized specimen, 52 ; width, 35 ; diameter, about 19 millimeters, but very irregular in different specimens.

This species is represented in the North Carolina Eocene by a single upper valve. It is smaller than most of the forms from Alabama. The exterior is worn and shows only a faint trace of the fine radial threads. It is indistinguishable from some individuals of $O$. falco from the type locality but differs from the figured type in having the pointed beak curve to the right instead of to the left; however, this seems to be a variable factor in the species. Height, 29 millimeters; width, 21 millimeters.

Locality: Biddle Landing, Neuse River, Craven County, N. C.

Geologic horizon: Castle Hayne marl, of Jackson Eocene age.

\section{Ostrea (Gryphaeostrea) subeversa Conrad}

Gryphaeostrea subeversa Conrad, Am. Jour. Conchology, vol. 1, p. 15, 1865; Checklist of the invertebrate fossils of North America, Eocene, p. 33, 1866.

Ostrea (Gryphaeostrea) subeversa Conrad. Dall, Wagner Free Inst. Sci. Trans., vol. 3, pt. 4, p. $681,1898$.

Cf. Ostrea lateralis Nilsson, Petrificata suessana formationis cretacaea, p. 29, pl. 7, figs. 7, 10, 1827, and Gryphaea canaliculata Sowerby, The mineral conchology of Great Britain, pl. 26, fig. 1, 1812 (as Chama).

?Gryphaea vomer Morton, Synopsis of the organic remains of the Cretaceous group, p. 54, pl. 9, fig. 5, 1834 (not in Acad. Nat. Sci. Philadelphia Jour., vol. 6, pl. 5, figs. $1-3,1828$ ).

Gryphostrea eversa (Deshayes) Conrad, op. cit. (1866), p. 3.

Ostrea eversa (Melleville) Heilprin, U. S. Geol. Survey Fourth Ann. Rept., p. 310, pl. 64, figs. 5-8, 1884.

Gryphaea eversa Melleville, Mémoire sur les sables tertiaires inférieurs du bassin de Paris, p. 41, No. 18, pl. 3, figs. $3,4,1843$.

Shell small, with discrepant valves; attached valve deep, oval, thin, without definite sculpture; beak indistinct and curved laterally; margin entire; free valve flat, oval, with sculpture of distant, elevated, concentric laminae. Longest diameter, 14 millimeters.

The writer has compared this shell with Melleville's species from the Paris Basin and with specimens from the "Zeuglodon beds" of Alabama and can see no constant difference by which they can be distinguished. The specimen from North Carolina is a young shell.

Locality: 6 miles west of Pink Hill, Duplin County, N. C.

Geologic horizon: Castle Hayne marl, of Jackson Eocene age. 


\section{Superfamily PECTINACEA}

\section{Family PECTINIDAE}

Genus PECTEN Müller

\section{Pecten (Chlamys) membranosus Morton}

Pecten membranosus Morton, Synopsis of the organic remains of the Cretaceous group, p. 59, pl. 10, fig. 4, 1834.

Dall, Wagner Free Inst. Sci. Trans., vol. 3, pt. 4, p. 736, 1898.

Pecten carolinensis Conrad. Kerr, Report of the geological survey of North Carolina, Appendix, p. 18, pl. 3, fig. 2, 1875 (not Lyropecten carolinensis Conrad, 1875).

Morton describes this species as "orbicular, convex, somewhat gibbous in the center, with about 80 distinct costae, the alternate ones being smaller." Dall has compared the types of Pecten carolinensis Conrad with that of $P$. membranosus Morton, and there is no doubt of their identity. Conrad's brief description is therefore quoted here:

Shell ovate, convex, ribs numerous, narrow, densely and minutely crenulated, rounded, alternating with two smaller interstitial radii which are also crenulated.

$P$. membranosus is one of the most abundant and characteristic fossils of the Castle Hayne marl. It is very widespread and as a rule is perfectly preserred. A more critical description of it will therefore be of value.

Shell suborbicular, slightly oblique, moderately convex, with nearly equal valves and from 22 to 35 primary radial ribs alternating with two secondary ribs, more or less strongly developed; submargins finely ribbed. Primary and secondary ribs bear coarse and closely spaced imbrications. Anterior ears longer and sculptured with four or five coarse imbricated radiating ribs; posterior ears with finer radiating ribs; byssal notch of moderate depth; ctenolium present. Interior of valves smooth, with margin slightly beveled; muscle scar high and slightly posterior. Dimensions of left valve: Height, 32.5 millimeters; breadth, 34 millimeters; depth, 6 millimeters.

Localities: Wilmington and $31 / 2$ miles northwest of Wrightsboro, New Hanover County; Old Rocky Point quarry, Castle Hayne quarry, Northeast Cape Fear River $31 / 2$ miles above Castle Hayne Bridge, 3 miles northeast of Maple Hill, and 1 mile southwest of Maple Hill, Pender County; 5 miles east of Beulaville, $11 / 2$ miles northeast of Rose Hill, 2 miles south of Magnolia, and 5 miles west of Pink Hill, Duplin County; 4 miles south of Richlands, 1 mile southeast of Richlands, and $11 / 2$ miles southeast of Richlands, Onslow. County; 21/2 miles west of Dover, Jones County; 3 miles east of Quinerly, Craven County.

Geologic horizon: Castle Hayne marl, of Jackson Eocene age.

\section{Pecten (Chlamys) deshayesii Lea}

Pecten deshayesii Lea, Contributions to geology, p. 87, pl. 3 , fig. 66, 1833.

Pecten lyelli Lea, op. cit., p. 88, pl. 3, fig. 67 (young).

8 Pecten minutus Lea, op. cit., p. 88.

Not Pecten deshayesii Nyst, Description des coquilles et polypiers fossiles des terrains tertiaires de Belgique, p. 288, 1843.

Pecten deshayesii var. tirmus Gregorio, Monographie de la faune éocénique de l'Alabama, p. 181, pl. 21, fig. 15, 1890.

Pecten (Chlamys) deshayesii Dall, Wagner Free Inst. Sci. Trans., vol. 3, pt. 4, pp. 737-738, 1898.

The following description is the original diagnosis by Lea:

Shell orbicular, rather compressed; ears nearly equal substance of the shell rather thick; ribs about 21, large, alternating with as many small ones, all imbricate; beaks pointed. $* * *$ Length, 1.3; breadth, 1.3 inch.

Dall's description of Pecten deshayesii is more critical:

The shell is rather, variable, losing the concentric sculpture when worn. It has 15 to 21 ribs; the byssal notch is inconspicuous; in the right valve the ribs are strong and rounded on top with the concentric sculpture chiefly evident at their sides, the interspaces sparsely imbricated with one or two interstitial divaricate threads near the base; ears flattish, slightly scaly, with radical grooves, notch very shallow; left valve with the sculpture like that of $P$. wahtubbeanus but much less dense. Altitude and latitude 48 millimeters. There is hardly any room for doubt that Lea's other species are merely the immature stages of this same shell.

Localities: Wilmington, New Hanover County; half a mile northwest of Winsatt station and threequarters of a mile southwest of Comfort station, Jones County, N. C.

Geologic horizon: Castle Hayne marl, of Jackson Eocene age.

\section{Pecten (Pseudamusium) scintillatus Conrad}

Pecten (Eburneopecten) scintillatus Conrad, Am. Jour. Conchology, vol. 1, p. 140, pl. 10, fig. 4, 1865 (young shell).

Camptonectes scintillatus Conrad, Checklist of the invertebrate fossils of North America, Eocene, p. 23, 1866.

Camptonectes claibornensis Conrad, op. cit. (1866), p. 23 (name only).

Pecten claibornensis Harris, Arkansas Geol. Survey Rept. for 1892, vol. 2, p. 145, 1894; Acad. Nat. Sci. Philadelphia Proc. for 1896, p. 470 (name only), pl. 18, figs. 1, 2, 1896.

Pseudamusium claibornense Harris, Bull. Am. Paleontology, vol. 9, p: 43, pl. 7, fig. 1; 1897.

Conrad in 1865 described this species as follows:

Ovate, very thin in substance; umbo ventricose, narrow, apex acute; anteriorly the larger valve is marked with minute fine lines, having a shagreen-like character. The smaller valve of this species is unknown.

In 1892 Harris briefly described this form under the nथme P. claibornensis Conrad. Harris suspected and Dall has confirmed the opinion that Conrad's type of $P$. scintillatus is the young of $P$. claibornensis. $P$. 
claibornensis, as such, never received a formal diagnosis by Conrad. Harris refers to its characteristics as follows:

This rather small, thin Pecten, appearing smooth to the naked eye, when examined under a microscope is found to contain minute excurving radiate lines, especially near the anterior and posterior margins.

Only one specimen of $P$. scintillatus is included in the collection from North Carolina.

Locality: Castle Hayne quarry, Pender County, N. C.

Geologic horizon: Castle Hayne marl, of Jackson Eocene age.

\section{Pecten cushmani Kellum, n. sp.}

Plate II, Figure 1

Shell equivalve, equilateral, with 29 or 30 simple ribs and equal interspaces; concentric sculpture of fine growth lines, which on the ribs tend to form low lamellae; the ribs becoming smaller and crowded near the submargins; ears erect, extent of anterior ears unknown; ctenolium present; posterior ears small and decorated with five or six radiating ribs, crossed by numerous concentric rows of lamellae; margin of both valves crenulated within, and margin of left valve also beveled within. Height, 18 millimeters; breadth, about 17 millimeters; depth of left valve, 2.5 millimeters.

This species is closely related to $P$. cookei, which occurs at the same horizon. It differs from cookei in being equilateral and equivalved, in the less convexity of the valves, in the crowding of the ribs near the submargin, and in the erect position of the ears. $P$. cushmani also resembles $P$. suwaneensis Dall, from which it is distinguished by its greater number of ribs, by the crowding of the ribs near the submargins, by the less angular character of the inner marginal crenulations, and by the concentric sculpture of smoothly rolling growth lines instead of the wavy lines characteristic of suwaneensis.

Locality: Quinerly Bridge, Pitt County; 3 miles east of Quinerly, Craven County; 3 miles northeast of Maple Hill, Pender County, N. C.

Geologic horizon: Castle Hayne marl, of Jackson Eocene age.

\section{Pecten cookei Kellum, n. sp.}

Plate II, Figures 2-3

Shell suborbicular, slightly oblique, moderately convex, and nearly equivalved, the left valve being more convex; 28 to 31 rounded ribs with equal interspaces; ribs crossed by concentric rows of imbrications, which toward the periphery and submargins tend to be produced into blunt spines; the inner spaces sculptured with extremely minute diagonal striations; anterior ears larger, right anterior ear sculptured with three strong ribs, which are crossed by numerous concentric rows, of coarse lamellae; posterior ears oblique, with less pronounced radiating ribs and concentric imbrications; byssal notch approximately one-half the length of ear; ctenolium present; interior of valves grooved in accordance with external ribbing; the grooves becoming faint over medial portion of disk.

Dimensions of largest specimen: Height, 20.5 millimeters; breadth, 20 millimeters; depth of left valve, 4.5 millimeters.

Pecten cookei is very similar to $P$. suwaneensis Dall, from the Ocala limestone of Suwannee County, Fla. It differs from $P$. suwaneensis in having the disk oblique, the ribs more numerous, with shallower interspaces, the ears shaped differently, and the grooves on the inner margin less angulated.

$P$. cooke $i$ is named in honor of C. Wythe Cooke, geologist, of the United States Geological Survey.

Localities: Northeast Cape Fear River and $31 / 2$ miles above Castle Hayne Bridge, Pender County; 2 miles south of Magnolia, 6 miles west of Pink Hill, and Northeast Cape Fear River near Chinquapin, Duplin County; near Broadhurst Bridge over Neuse River and Sarpony Hills, Wayne County; $21 / 2$ miles west of Dover and 2 miles northwest of Wilcox Bridge over Trent River, Jones County, N. C.

Geologic horizon: Castle Hayne marl, of Jackson Eocene age.

\section{Pecten biddleana Kellum, n. sp. \\ Plate II, Figure 4}

Shell of medium size, equilateral; the left $v a l v e$ sculptured by 15 rounded primary ribs, alternating with wider interspaces in which are one or two low secondary ribs; submargins broad, steep, and smooth; ears oblique, sculptured with numerous fine radiating ribs and concentric imbrications; the umbonal point projects slightly above the hinge line; internal character of valve unknown.

The only specimen of this shell obtained from the type locality is a worn left valve. A single right valve collected at Polloksville, Jones County, N. C., appears to be the same species. The following paragraph is a description of this valve:

Shell similar to the left $v$ alve from Biddle Landing; sculptured by seventeen rounded ribs and nearly equal interspaces. In the center of each interspace is a single, very fine secondary rib. Entire surface sculptured with concentric laminae; inner margin strongly crenulated with angular grooves which disappear toward the center of the disk; umbonal point projects above the hinge line. Extent of ears unknown.

Dimensions of left valve from Biddle Landing: Height, 26.5 millimeters; breadth, 24.5 millimeters; dep th, about 3.5 millimeters; length of hinge line, 12.5 millimeters.

Localities: Biddle Landing, Neuse River, Craven County; Polloksville, Jones County, N. C.

Geologic horizon: Castle Hayne marl, of Jackson Eocene age. 


\section{Family SPONDYLIDAE}

Genus Plicatula Lamarck

Plicatula filamentosa Conrad

Plate II, Figures 5-6

Plicatula filamentosa Conrad, Fossil shells of the Tertiary formations, p. 38, 1833.

Dall, Wagner Free Inst. Sci. Trans., vol. 3, pt. 4, p. 762, 1898.

Plicatula mantelli Lea, Contributions to geology, pp. 89, 90, pl. 3, fig. 68, 1833.

Plicatula planata Aldrich, Cincinnati Nat. Hist. Soc. Jour., vol. 9, p. 45, pl. 2, fig. 20, 1866 (young shell).

Spondylus amussiopse Gregorio, Monographie de la faune éocénique de l'Alabama, p. 179, pl. 20, figs. 11-13, 1890 (young shell).

Plicatula filamentosa was first described by Conrad in 1833 as follows:

Shell suborbicular, narrowing toward the apex, much compressed; with seven costae; and densely imbricated with small, irregular, concentric wrinkles and with minute radiating lines. Breadth and length about three-fourths of an inch.

The characteristics of $P$. filamentosa are delineated by Dall in the following paragraph:

When young it has fine radial striation on both valves, which may sometimes be wholly or partly spiny (mut. planata), and the shell is flattish; this sculpture changes rather suddenly by appearance of the large plications, of which the lateral ones rarely bear a few coarse spines. The radial striation continued through life in well-developed specimens and may be recognized in unworn shells. There are sometimes well-marked auricles developed near the beaks. The interior of the young, as noted by Gregorio, presents a few strong lirae resembling those of Propeamusium; these persist until middle age, especially distally, but on the disk are gradually buried in shelly matter. The thickened ends of the lirae are visible longer but gradually disappear, their position in the adult being marked by small pits.

This species has been found at two localities in the Eocene of North Carolina. The shell itself is preserved in most specimens and though weathered still shows the delicate radial and concentric sculpture. Many specimens are attached over a large portion of the valve, so that the large plications are confined to the margin.

Localities: Wilmington, New Hanover County; 10 miles northwest of Jacksonville, Onslow County, N. C.

Geologic horizon: Castle Hayne marl, of Jackson Eocene age.

\section{Genus SPONDYLUS Linné}

Spondylus lamellacea Kellum, n. sp.

Plate II, Figures 7-9

Shell extremely variable in size and shape; largest specimen about 80 millimeters in height; subcircular or lsubovate in marginal outline. Attached valve inflated at the umbones and flattening toward the margin; radially sculptured with low ridges, some of which bear thin spines; concentrically sculptured with fine growth lines superimposed on low, irregular waves; locally the spines are replaced by high, thin, and sharp lamellae, which extend concentrically around the shell, from 3 to 8 millimeters apart. Some of these lamellae project as much as 12 millimeters above the surface of the test; the side toward the umbo is practically smooth; that facing the margin is ribbed, suggesting that the lamellae are formed by the coalescence of the spines. In some specimens the surface of the attached valve seems to be covered with the lamellae and to bear few if any spines. The interior of the valve shows coarse radial ribbing, with wider interspaces and some irregular secondary ribs. The free valve is nearly flat, being very slightly inflated at the umbo; exterior sculpture of moderately fine primary and secondary ribbing, with innumerable long, thin spines which lie at a low angle to the surface of the shell: The interior of the free valve has broad, flat ridges with narrow, rounded interspaces.

Dimensions of large, subcircular individual: Height, 80 millimeters; breadth, 73 millimeters; depth of both valves together, about 35 millimeters.

This species occurs rather abundantly at sereral localities in North Carolina. It is usually preserved as very perfect internal casts, to some of which fragments of the shell adhere. The cardinal area is unknown, and the character of the teeth, which appear to be thick and strong, is known only from their impression on the cast. The most typical and distinguishing feature of the species is the sculpture of thin, high, concentric lamellae on the attached valve.

Spondylus lamellacea appears to be closely related to S. gregalis, from the "Lower Green Marls" (Cretaceous) of New Jersey. S. gregalis is also characterized by elevated lamellae. The writer has seen only figures of the New Jersey species. It seems to differ from $S$. lamellacea by the more regular and finer ribbing of the interior of the attached valve and the total absence of secondary ribs. The lamellae do not appear so greatly elevated as in the North Carolina species.

Localities: Wilmington, New Hanorer County; old Rocky Point, Northeast Cape Fear River, and 31/2 miles above Castle Hayne Bridge, Pender County, N. C.

Geologic horizon: Castle Hayne marl, of Jackson Eocene age.

\section{Superfamily ANOMIACEA \\ Family ANOMIIDAE \\ Genus ANOMIA (Linné) Muller}

Anomia sp.

Plate II, Figure 10

Shell thin, translucent; rounded to oral in outline; superior valve strongly convex or inflated; umbone indistinct; exterior surface with very faint concentric 
growth striations. Lower valve and interior scars of upper valve unknown.

This form resembles Anomia simplex D'Orbigny, a Miocene species. It is too poorly preserved for specific identification.

Localities: 3 miles northeast of Maple Hill, Pender County; 5 miles west of Pink Hill, Duplin County; 3 miles east of Quinerly, Craven County, N. C.

Geologic horizon: Castle Hayne marl, of Jackson Eocene age.

\section{Order ANOMALODESMACEA}

\section{Superfamily ANATINACEA}

Family PHOLADOMYIDAE

Genus PHOLADOMYA Sowerby

Pholadomya claibornensis Aldrich

Pholadomya claibornensis Aldrich, Alabama Geol. Survey Bull. 1, p. 38 , pl. 4 , fig. 5,1886 .

The following is Aldrich's original description of this species:

Shell exceedingly thin, pearly, concentrically ribbed, crossed by radial lines, which are strong on the umbones; beak high, very prominent close to the anterior end of shell, anterior truncated abruptly; posterior produced, flattened on the upper part; lunule long and narrow, smooth; hinge raised, prominent.

Locality: Lisbon and beds at base of Claiborne Bluff, Ala.

This species is close to $P$. marylandica Conrad but appears to differ from that species in height of beaks and their more anterior position, besides being abruptly truncated and posteriorly flattened.

This species is rare in the Eocene of North Carolina, only a few individuals having been found at Wilmington. They do not have the extremely high beaks of Aldrich's figure, but this appears to be an individual characteristic.

Locality: Wilmington, New Hanover County, N. C. Geologic horizon: Castle Hayne marl, of Jackson Eocene age.

\section{Superfamily POROMYACEA \\ Family EUCIROIDAE \\ Genus PECCHIOLIA Meneghini \\ Pecchiolia dalliana Harris}

Pecchiolia dalliana Harris, Bull. Am. Paleontology, vol. 8, No. 33, p. 16, 1919.

Harris's description is quoted below:

Size and general appearance as indicated by the figure; extremely inflated and generally exogyroid surface marked by numerous radiating small ribs, becoming stronger and farther apart as the position of the umbonal ridge is approached; there occasional inter-riblets appear; passing the umbonal ridge the strength of the ribs decreases to the ligamental margin; a radiating channel divides the postumbonal into two nearly equal portions; concentric markings consist of numerous rather irregular and ill-defined undulations, strongest basally.

The shell is strikingly similar to $P$. wemmelensis Vincent, from the "Sables de Wemmel" (Bull. Soc. roy. mal. de Belgique, vol. $32,1897, \mathrm{p} . \mathrm{XXX}$ ) and, since these sands are the equivalent of the Barton beds of England, one instinctively thinks of the aid, small though it may be, that this form may render us in correlating the upper Eocene deposits on either side of the Atlantic.

Our specimen is mainly in form of a cast from the city quarry, near Wilmington, N. C., found among many other beautiful molluscan remains, echinoderms, and brachipods.

We take great pleasure in styling this the Dall Pecchiolia, not only on account of the great and valuable Tertiary work of this author, but especially on account of his early extensive and painstaking work on this branch of Pelecypoda.

Type: Deposited by Harris in museum at Cornell.

Localities: Wilmington, New Hanover County; old Rocky Point quarry and 1 mile northeast of Lane's Ferry, Pender County; N. C.

Geologic horizon: Castle Hayne marl, of Jackson Eocene age.

\section{Order TELEODESMACEA}

Superfamily ASTARTACEA

Family CRASSATELLITIDAE

Genus CRASSATELLITES Krüger

Crassatellites alta (Conrad)

Crassatella alta Conrad, Fossil shells of the Tertiary formations, vol. 1, No. 2, p. 21, pl. 7, 1832.

Conrad describes this species as follows:

Suboval, thick and ponderous, compressed; anterior margin obtusely rounded; posterior margin broad and slightly angular; beaks with regular concentric grooves, somewhat angulated behind; inner margin crenulated.

Locality: Claiborne, Ala. Middle Tertiary.

This fine species is allied to C. tumida Lamarck, but is proportionally shorter, and the beaks more central. The cartilage still remains in the valve here represented, and the shell is in the finest state of preservation.

This well-known species is rather common in the Eocene beds at Wilmington. Here it is preserved as large, perfect casts. It has also been reported from the Castle Hayne marl at the old Rocky Point quarry, in Pender County, N. C.

\section{Crassatellites sp. $a$}

\section{Plate III, Figure 1}

Internal cast of medium size; equivalved, inequilateral, subquadrate in marginal outline; beaks at anterior third of valve; postumbonal ridge strong; muscle scars and pallial line distinct; basal margin finely crenulated; exterior sculpture of regular, concentric, moderately coarse growth lines. Dimensions of large specimen: Length, 50 millimeters; height, 34 millimeters; depth of single valve, 13 millimeters.

Locality: Wilmington, New Hanover County, N. C.

Geologic horizon: Castle Hayne marl, of Jackson Eocene age. 
Crassatellites sp. $b$

Plate III, Figure 2

Internal cast similar to Crassatellites sp. $a$ but distinguished from it by having the valves more inflated and more abruptly terminated posteriorly, the beaks higher and slightly more anterior, and the postumbonal ridge more rounded. Dimensions of medium-sized specimen: Length, 37 millimeters; height, 31 millimeters; depth of single valve, 10 millimeters.

Localities: Wilmington, New Hanover County; old Rocky Point quarry, Pender County, N. C.

Geologic horizon: Castle Hayne marl, of Jackson Eocene age.

\section{Superfamily CARDITACEA \\ Family CARDITIDAE \\ Genus VENERICARDIA Lamarck \\ Venericardia nasuta Dall? \\ Plate III, Figure 3}

Venericardia nasuta Dall, Wagner Free Inst. Sci. Trans., vol. 3 , pt. 6, p. 1425, 1903

Dall's description is quoted below.

Eocene of Conecuh County; L. C. Johnson.

Shell very inequilateral, elongate; solid, with large prosogyrate, nearly anterior beaks; anterior end short and rounded, posterior produced, decurved, subrostrate, terminally rounded; sculpture of about $25 \mathrm{low}$, carinate, obscura $\mathrm{j}^{r}$ beaded radial ribs, of which the posterior 10 are nearly simple, the others accompanied, more or less distinctly, by smaller lateral threads, one on each side; basal margin slightly incurved, lunule small, hinge of Venericardia, inner margin crenulated rather deeply. Length, 41, height, 27, diameter, 26 millimeters, the anterior end 6 millimeters before the vertical of the beaks.

This form has much the outline of a Cardita but all the usual characters of Venericardia. Mr. Johnson labeled it as from the Midway horizon, but this may have been only a surmise, no outcrop of that horizon being mapped in the county, and no exact locality assigned to the type specimen.

The writer has a single well-preserved internal cast, from the City Rock quarry at Wilmington, N. C., which is believed to be this species. Comparison with an internal cast of Dall's type appears to show that it is identical.

Geologic horizon: Castle Hayne marl, of Jackson Eocene age.

\section{Venericardia sp. \\ Plate III, Figure 4}

Internal cast of medium size, inflated, subcircular in marginal outline; umbones narrow, prosogyrate; anterior adductor muscle scar large and prominent on cast; surface of cast with numerous well-defined radiating ridges extending from the umbonal area to the margin; a posterior lateral tooth indicated, dentition otherwise unknown. Dimensions of left valve of small individual: Height, 17 millimeters; breadth, 16.5 millimeters; diameter, about 8 millimeters.
Locality: Wilmington, New Hanover County, N. C. Geologic horizon: Castle Hayne marl, of Jackson Eocene age.

\author{
Superfamily CHAMACEA \\ Family CHAMIDAE \\ Genus CHAMA (Linné) Bruguière
}

Chama sp. $a$

Plate III, Figure 5

Internal cast of right valve large, inflated, quadrilateral in marginal outline, and twisted anteriorly; beak blunt, not elevated above the margin of the shell; posterior adductor muscle scar suboval; pallial line distinct; dental area of cast indicates a single lateral tooth. Exterior characters of shell unknown. Dimensions of large cast: Longest diameter of margin, 35 millimeters; depth of right valve, 22 millimeters.

Locality: Wilmington, New Hanover County, N. C.

Geologic horizon: Castle Hayne marl, of Jackson Eocene age.

\section{Chama sp. $b$}

\section{Plate III, Figure 6}

Internal cast small, very irregular in shape, roughly quadrilateral in marginal outline; right valve strongly. twisted anteriorly, with beak greatly elevated; left valve depressed, with beak low, blunt, and slightly twisted; adductor muscle scars suboval; pallial line distinct. Exterior of shell unknown.

This form is distinguished from Chama sp. a, described above, by its smaller size, more irregular shape, and greater twist and elevation of the beak on the right valve.

Localities: Wilmington, New Hanover County; old Rocky Point, Pender County, N. C.

Geologic horizon: Castle Hayne marl, of Jackson Eocene age.

Superfamily LUCINACEA

Family LUCINIDAE

Genus IUCINA (Bruguière) Lamarck

Lucina sp.

Plate III, Figure 7

Internal ${ }^{\circ}$ ast small, profoundly inflated, subcircular in marginal outline; anterior and posterior adductor muscle scars greatly elongated; pallial line distinctly impressed on cast. Dimensions of large individual: Length, 13 millimeters; height, 11 millimeters; depth of both valves together, 7 millimeters.

Localities: Wilmington, New Hanover County; old Rocky Point, Pender County, N. C.

Geologic horizon: Castle Hayne marl, of Jackson Eocene age. 


\section{Genus PHACOIDES Bainville}

\section{Phacoides (Miltha) pandatus (Conrad)?}

Lucina pandata Conrad, Am. Jour. Sci., vol. 23, p. 343, January, 1833; Fossil shells of the Tertiary formations, No. 4, p. 40, October, 1833.

D'Orbigny, Prodrome de paléontologie, p. 387, 1850.

Phacoides (Miltha) pandatus Conrad. Dall, Wagner Free Inst. Sci. Trans., vol. 3, pt. 6, pp. 1374-1375, 1903.

Lucina compressa Lea, Contributions to geology, p. 55, pl. 1, fig. 27, December, 1833.

Aldrich, Alabama Geol. Survey Bull. 2, pp. 9, 37, 1886.

Gregorio, Monographie de la faune éocénique de l'Alabama, p. 206, pl. 29, figs. 1, 2-5, 1890.

Cyclas pandata Conrad, Am. Jour. Conchology, vol. 1, p. 8, 1865.

Lucina (Miltha) compressa Cossmann, Notes complémentaires sur la faune éocénique de l'Alabama, p. 11, 1894.

Conrad's original description is as follows:

Shell oval, compressed, obscurely cancellated; anterior side somewhat corrugated; beaks nearly central; teeth three in one valve; anterior muscular impression profoundly elongated; lunule excavated, minute. Length, $11 / 4$ inches. This shell is allied to Lucina mutabilis Lamarck.

Phacoides pandatus is common in the Eocene beds at Wilmington. It has been found there only as internal casts, the shell itself having been entirely dissolved away. Some individuals are more inflated than the Claiborne forms but otherwise appear to be identical.

Locality: Wilmington, New Hanover County, N. C. Geologic horizon: Castle Hayne marl, of Jackson Eocene age.

\section{Superfamily ISOCARDIACEA \\ Family ISOCARDIIDAE \\ Genus MEIOCARDIA Adams \\ Meiocardia carolinae Harris}

Meiocardia carolinae Harris, Bull. Am. Paleontology, vol. 8, No. 33, p. 14, pl. 2, figs. 5, 6, 1919.

Harris gives the following description:

Size and general appearance as indicated by the figures; inflated, with a well-defined postumbal slope, on which about two-fifths way from the ridge to the ligamental margin there is a well-defined radiating . ridge; traces of interior radiating lines sometimes present; marginal impressions indicating a fairly thick shell; concentric undulations noticeable basally and posteriorly.

Small casts of these species are common at Wilmington and Eutaw Springs. Sometimes at the former locality specimens the size of Figure 5 are found. An impression of the exterior of what appears to be the same species is in our collections, labeled "Neuse River 16-17 miles above New Bern, N. C." This shows, besides rather regular concentric undulations posteriorly, fine concentric lining. These lines are almost rectilinear medially but curve up rather abruptly anteriorly and posteriorly. This reminds one of Dall's M. agassizi, a recent West Indian species.

Types: Paleontological Museum, Cornell University.

Localities: Eutaw Springs, S. C.; Wilmington, N. C., and Neuse River above New Bern.
Superfamily VENERACEA

Family VENERIDAE

Subfamily MERETRICINAE

Genus PITARIA Roemer

Pitaria securiformis (Conrad)?

Dione securiformis Conrad, Am. Jour. Conchology, vol. 1, p. 137, pl. 10, fig. 1, 1865.

Conrad says:

Subcordate, ventricose, with concentric recurved ribs; anterior margin acutely rounded; posterior extremity subtruncated; lunule cordate, defined by a slightly impressed line; right valve-cardinal teeth approximate curved, direct.

The type locality of this species is Garlands Creek, Clarke County, Miss.

Pitaria securiformis occurs abundantly in the Eocene of North Carolina. It is preserved in the form of internal and external casts of the shell. Comparison with casts from Mississippi leaves little doubt that they are the same species.

Geologic horizon: Castle Hayne marl, of Jackson Eocene age.

\section{Superfamily MYACEA \\ Family GASTROCHAENIDAE \\ Genus GASTROCHAENA (Spengler) Cuvier \\ Gastrochaena sp. \\ Plate III, Figure 8}

Internal cast large, equivalve, inequilateral, ovoid, gaping, with the umbones anterior; distinct concentric coarse sculpture on cast, with a single median radial groove extending from the umbone to the distal margin. Dimensions of small individual: Length, 15 millimeters; height, 7 millimeters; depth of single valve, about 2.5 millimeters.

To one individual of this species, from the City Rock quarry at Wilmington, adberes the cast of the flasklike burrow which is characteristic of the genus.

Locality: Wilmington, New Hanover County, N. C.

Geologic horizon: Castle Hayne marl, of Jackson Eocene age.

\section{Class GASTROPODA \\ Order ASPIDOBRANCHIA \\ Family PLEUROTOMARIIDAE \\ Genus Pleurotomaria Defrance}

Pleurotomaria hanoverensis Kellum, n. sp.

Plate IV, Figures 1-2

This species is represented by a single cast of the exterior of the shell. The specimen shows six whorls on which a minute spiral sculpture is almost perfectly preserved. Whorls subcircular in cross section; sutures slightly impressed; spire moderately 
elevated; shell perforate; surface sculpture of fine spiral cords alternating with finer threadlike lines and crossed by axial threads, which are recurved at the center of the whorl reflecting the slit in the outer lip of the aperture. A spiral band of three coarse cords, cancellated by fine threads, follows the center of the whorls. Height of type specimen, 33 millimeters; diameter unknown.

Locality: Wilmington, New Hanover County, N. C.

Geologic horizon: Castle Hayne marl, of Jackson Eocene age.

\section{Pleurotomaria sp. $a$}

Plate IV, Figure 3

In the collection of the United States National Museum there are several casts of a large Pleurotomaria from the City Rock quarry at Wilmington. The best-preserved specimen consists of parts of two whorls and retains a small portion of the original shell. Axial growth lines on the basal whorl are curved backward about midway between the sutures, reflecting the slit in the outer lip of the aperture. Whorls concave on top where the overlying whorl rests upon them; outer side of whorls slightly flattened giving the whole shell a more regular conical shape. Diameter of base of cast, 108 millimeters.

This specimen may be the one referred to by Dall ${ }^{28}$ as follows:

In the Eocene a large and fine species, recalling $P$. adamsoniana, has been described by Tuomey (Proc. Acad. Nat. Sci. for 1852 , p. 193, 1854) from the limestones of Wilmington, N. C., under the name of Trochus nixus. It has never been figured, but a fine specimen is in the national collection from the original locality.

Tuomey's description is here quoted:

Large; axis very oblique; whorls five or six, flat or slightly concave, marked by revolving lines obsoletely cancellated; suture of the cast deep, of the shell basely impressed; umbilicus open, deep. Dimensions: Spiral angle, $74^{\circ}$; height, 4 ; breadth, 5 inches.

Locality: Wilmington, New Hanover County, N. C. Geologic horizon: Castle Hayne marl, of Jackson Eocene age.

\section{Pleurotomaria sp. $b$}

Plate IV, Figure 4

The most complete specimen of this species in the National Museum is an internal cast of three complete whorls, to which a small fragment of the original shell material is attached. Cast large, conical, with elevated spiral; surface obliquely flattened between the sutures in the direction of the spire; whorls concave on top and convex on the lower side; base subcircular, with a large perspective umbilicus in which all the volutions would be shown in a perfect specimen; periphery of base angular; shell thick, sculpture

s8 Dall, W. H., Wagner Free Inst. Sci. Trans. vol. 3, pt. 2, p. 423, 1882. unknown. Diameter of base, 11.3 centimeters; apical angle, $74^{\circ}$; height unknown.

This species strikingly resembles Leptomaria gigantea Whitfield, from the Eocene layers of the "Upper Bed Greensand Marls" of New Jersey. The writer has seen only the figure of Whitfield's species, but the fragmentary character of the North Carolina specimens makes a specific determination impossible.

Locality: Wilmington, New Hanover County, N. C.

Geologic horizon: Castle Hayne marl, of Jackson Eocene age.

\section{Family FISSURELLIDAE \\ Subfamily EMARGINULINAE \\ Genus FISSURIDEA Swainson}

Fissuridea penderensis Kellum, n. sp.

\section{Plate III, Figure 9}

Shell large, of medium height, narrowed at the anterior end, regularly oval on the posterior end; foramen large, about 6 millimeters long; shell radially sculptured with about 34 strong primary ribs, generally with three secondary ribs between; concentric sculpture of evenly spaced threads, which are inconspicuous near the margin but toward the apex equal the secondary ribbing and give that part of the shell a regular, finely cancellated sculpture. Longest diameter, about 38 millimeters; median breadth, about 24 millimeters; altitude, about 12 millimeters.

The type of this species is an excellent cast of the exterior of the shell, preserving the finest details of the sculpture.

$F$. penderensis is similar to $F$. mauri Aldrich, ${ }^{29}$ from Matthews Landing, near Oak Hill, Ala. It differs from $F$. mauri, however, in the larger foramen, in the absence of marginal crenulations within, and in having three secondary ribs instead of two between the primary ribs.

Locality: Old Rocky Point, Pender County, N. C. Geologic horizon: Castle Hayne marl, of Jackșon Eocene age.

\section{Fissuridea sp.}

Plate III, Figure 10

Cast small, oval, moderately elevated, narrowing anteriorly; apex slightly anterior; foramen oval, 2.5 millimeters in longest diameter; surface of cast smooth except for pallial line and sinuses. Surface of shell unknown. Longest diameter, 23 millimeters; breadth, 16 millimeters; height, 7 millimeters.

The general appearance of this form is similar to that of Fissuridea marlboroensis Clark, from the Eocene of Maryland.

Locality: Wilmington, New Hanover County, N. C. Geologic horizon: Castle Hayne marl, of Jackson Eocene age.

${ }^{20}$ Aldrich, T. H., New Eocene fossils from the Southern States: Nautilus, vol. 24, No. $7,1910$. 


\section{Genus EMARgINULA Lamarck \\ Emarginula sp. $a$; \\ Plate IV, Figure 5}

Internal cast oval, cap-shaped, with apex slightly posterior to the center; anterior slope convex, posterior slope shorter, concave; anterior marginal notch deep and narrow. Surface of cast smooth; external sculpture of shell unknown. Longest diameter, 19 millimeters; breadth, 15 millimeters; height, 9 millimeters.

This species is similar in general contour to Emarginula pilsbryi Dall, from the Caloosahatchee marl of Florida. The margin of the internal cast does not, however, reflect the external ribbing of the shell as in that species.

There is only one individual of this species in the collection of the National Museum from North Carolina.

Locality: Wilmington, New Hanover County, N. C.

Geologic horizon: Castle Hayne marl, of Jackson Eocene age.

\section{Emarginula sp. $b$ \\ Plate IV, Figure 6}

Cast conical, moderately elevated, oval in outline, narrowing anteriorly; the apex in posterior third of shell; anterior slope convex, posterior slope concave; surface of cast shows radial lines near apex and coarse crenulations toward margin; anterior slit deep and narrow. Longest diameter, 26 millimeters; breadth, about 19 millimeters; height, 10 millimeters.

This species differs from Emarginula sp. $a$, described above, in its larger size and less steeply inclined sides and in the presence of radial marking on the internal cast.

Locality: Old Rocky Point, Pender County, N. C.

Geologic horizon: Castle Hayne marl, of Jackson Eocene age.

Family TROCHIDAE

Genus CaLliostoma Swainson

Calliostoma sp.

Plate IV, Figure 7

Internal cast of medium size, coiled, conic, with elevated spire; the most complete specimen has six whorls, subrhomboidal in cross section, rounded on lower side and flattened or slightly concave on top; sutures of cast deep; sculpture of shell unknown. Diameter of base, 25 millimeters; height, 15 millimeters; apical angle, $83^{\circ}$.

Localities: Wilmington, New Hanover County; Old Rocky Point, Pender County, N. C.

Geologic horizon: Castle Hayne marl, of Jackson Eocene age.

\section{Order CTENOBRANCHIATA}

Family EPITONIIDAE

Genus EPITONIUM Bolten

Epitonium aequabile Kellum, n. sp.

Plate V, Figure 1

Shell small, spiral, with five or more regularly rounded whorls; sutures distinct; spiral sculpture of numerous low, rounded cords with nearly equal interspaces; varices of equal size, rounded, regularly spaced, and opposite on contiguous whorls. Base, aperture, and apex of shell unknown. Height of figured type, 7.5 millimeters; diameter at base, 3 millimeters.

This species appears to be similar to the Scala sp. figured by G. D. Harris. ${ }^{30}$ Harris's species, which was not named or described, shows only a suggestion of spiral sculpture, but on $E$. aequabile the sculpture is very distinct.

Locality: Wilmington, New Hanover County, N. C. Geologic horizon: Castle Hayne marl, of Jackson Eocene age.

\section{Epitonium dignitatis Kellum, n. sp.}

\section{Plate V, Figure 2}

Shell of seven or more whorls, tapering, moderately slender; spirally sculptured with about seven irregularly spaced rounded ridges between the sutures and with fine secondary lines uniformly covering these coarser ridges and interspaces; axial sculpture of two prominent, sharply keeled, and slightly inclined major varices to every whorl; each varix being offset toward the aperture with respect to the corresponding varix of the preceding whorl. Between the major varices are 10 to 20 thin, sharp-edged minor varices on each half whorl, the number being greatest on the bottom whorl and decreasing toward the apex. The basal area is separated from the last whorl by a strong, rounded keel overrun by the varices. Aperture and apex unknown. Height, 37 millimeters; maximum diameter, about 17 millimeters.

$E$. dignitatis is closely related to Scala ranellina Dall, which occurs at the same horizon in Alabama. It differs from that species in the greater number of whorls, in the more numerous minor varices between the major ones, and in having the major varices somewhat less prominent and regularly spaced.

Locality: Wilmington, New Hanover County, N. C. Geologic horizon: Castle Hayne marl, of Jackson Eocene age.

${ }^{30}$ Arkansas Geol. Survey Rept. for 1892, vol. 2, p. 45, pl. 3, fig. 2, 1894. 


\section{Family CALYPTRAEIDAE \\ Genus CaLYPTRAEA Lamarck \\ Calyptraea sp. \\ Plate V, Figure 3}

Internal cast large, depressed, coiled, with about two and one-half whorls; suture distinct; surface of cast smooth. Height, 14 millimeters; diameter, 33 millimeters.

This species is very much like Calyptraca trochiformis but is much more depressed than the larger specimens of that species.

Locality: Wilmington, New Hanover County, N. C.

Geologic horizon: Castle Hayne marl, of Jackson Eocene age.

\section{Family XENOPHORIDAE \\ Genus XENOPHORA Fischer. \\ Xenophora sp. \\ Plate V, Figure 4}

This species is probably Xenophora conchyliophora (Born), which is reported ${ }^{31}$ to range from the Cretaceous to the Recent. It occurs abundantly in the Eocene of North Carolina but is preserved only in the form of casts of the interior, which do not lend themselves to specific determination.

Cast conical, depressed, imperforate; whorls flattened on lower side and flattened or slightly concave on top, subrhomboidal in cross section; sutures not deeply impressed; surface of cast roughened by irregular furrows or waves. Diameter of base, 29 millimeters; height, about 18 millimeters.

Localities: Old Rocky Point, Pender County; Wilmington, New Hanover County, N. C.

Geologic horizon: Castle Hayne marl, of Jackson Eocene age.

\section{Family TURRITELIIDAE \\ Genus TURRITELIA Lamarck \\ Turritella subtilis Kellum, n. sp. \\ Plate V, Figure 5}

Shell coiled, slender, tapering; suture simple, distinct, not deeply impressed; sculpture delicate; whorls divided into three subequal parts by two low, sharp spiral threads, between which is a third, less prominent thread; lower whorls have, at base bordering the suture, another spiral thread, which becomes obsolete in the higher whorls; indistinct axial growth lines. Total number of whorls and shape of aperture unknown. Length of fragment of 10 whorls, 24 millimeters.

The type specimen of this species is a cast of the exterior of the shell, preserving the most delicate sculpture.

Locality: Wilmington, New Hanover County, N. C. Geologic horizon: Castle Hayne marl, of Jackson Eocene age.
Turritella sp.

Plate V, Figure 6

Cast small, acute conic; whorls more than twice as wide as high, rhomboidal in cross section; surface smooth, slightly concave, with a fine spiral groove along under side of whorl. Length of fragment of $31 / 2$ whorls, 24 millimeters; breadth of basal whorl, 11 millimeters.

This form, which occurs at Rocky Point only in the form of casts of the interior, is suggestive of Turritella carinata Lea. It can not, however, be determined specifically.

Locality: Old Rocky Point, Pender County, N. C.

Geologic horizon: Castle Hayne marl of Jackson Eocene age.

\section{Family VERMICULARIIDAE \\ Genus SILIQUARIA Lamarck}

Siliquaria vitis Conrad

Shell irregularly spiral toward the top, with slightly elevated longitudinal lines; fissure narrow; greatest diameter, one-fourth of an inch. Locality, Claiborne, Ala.-Conrad, August, 1833.

Contorted, with longitudinal ribs becoming obsolete inferiorly; wrinkled transversely; fissure inarticulate. Synonym, S. claibornensis Lea. Locality, Claiborne, Ala.-Conrad, March, 1835.

Regarding the range of this species Dall ${ }^{32}$ says:

Eocene of the Claiborne sands, Conrad and Lea; older Miocene of the Orthaulax bed, Ballast Point, Tampa Bay, Florida, Dall. I can see no distinguishing characters between specimens from the upper Eocene and those of the lower Miocene.

Cast spirally tapering, subcircular in cross section; surface smooth except for a longitudinal plication caused by the fissure. Some specimens show also a single longitudinal, broad, shallow groove; a few have horizontal waves or wrinkles.

This species occurs abundantly in the Eocene beds at Rocky Point, N. C. It is preserved, however, only as casts of the interior.

Localities: Wilmington, New Hanover County; old Rocky Point, Pender County, N. C.

Geologic horizon: Castle Hayne marl, of Jackson Eocene age.

Family STROMBIDAE

Genus STROMBUS Linné

Strombus sp.?

Plate V, Figure 7

Cast of medium size, conic, with about five whorls, spire comparatively low; shoulders rounded; body whorl with faint nodes or angles along the carina and upper part of whorl, suggesting radial sculpture of the shell; body whorl toward the aperture partly climbs

32 Dall, W. H., Wagner Free Inst. Sci. Trans., vol. 3, pt. 2, p. 307, 1892. 
the spire. Shell sculpture, genital sulcus and canal unknown. Height 53 millimeters; maximum diameter, 28 millimeters.

The single specimen of this species collected from Wilmington is a good cast but does not show the character of the aperture of the shell. It may possibly belong to the genus Plejona, though no dollumellar folds are visible. It is referred to the genus Strombus primarily because of the ascending character of the body whorl toward the aperture.

Locality: Wilmington, New Hanover County, N. C.

Geologic horizon: Castle Hayne marl, of Jackson Eocene age.

\section{Family CYPRAEIDAE \\ Genus CYPRAEA Linné \\ Cypraea sp. $a$}

Plate V, Figure 8

Cast of medium size, rotund; aperture moderately wide, finely denticulate on right and left lips, canaliculated at anterior end; spire exposed and prominently elevated; surface of cast smooth. Height, 27 millimeters; maximum diameter, 20.5 millimeters.

This form differs from Cypraea sp. $b$, described below, in the prominent elevation of the spire.

Locality: Wilmington, New Hanover County, N. C. Geologic horizon: Castle Hayne marl, of Jackson Eocene age.

\section{Cypraea sp. $b$}

Plate V, Figure 9

Cast ovoid, ventricose; aperture wide, extending the whole length of the shell, canaliculated at anterior extremity; right and left lips coarsely and regularly crenulated; spire exposed, very slightly elevated; top of right lip extends higher than apex; surface of cast smooth.

Maximum diameter of large, imperfect cast, 22 millimeters. Dimensions of smaller, perfect cast: Height, 20 millimeters; maximum diameter, 16 millimeters.

This form differs from species $c$ and $d$ in.having the spipexposed and slightly elevated.

Locallities: Wilmington, New Hanover County; old Rocky Point, Pender County, N. C.

Geologic horizon:- Castle Hayne marl, of Jackson Eocene age.

\section{Cypraea sp. $c$ \\ Plate V, Figure 10}

Cast of medium size, solid, suboval in marginal outline; aperture moderately narrow, with right lip coarsely denticulate; apex forms a cup-shaped depression, exhibiting the volutions in the center; surface of cast shows faint horizontal and vertical striations, reflecting the external sculpture of the shell. Height, 27 millimeters; largest diameter, 20 millimeters.
This species is very similar to Cypraea casts collected from the Mc Connico place, Wilcox County, Ala. The horizon there is Midway. It differs from the Alabama specimens, however, in being slightly less bulbous and in having the outer lip thinner, the aperture narrower, and striations present on the cast.

The named species closest to this one from the North Carolina Eocene is C. problematica Heilprin, from Florida. The cup-shaped depression at the apex, however, does not contain the nuclear tip as in the Florida species.

Localities: Wilmington, New Hanovèr County; old Rocky Point, Pender County, N. C.

Geologic horizon: Castle Hayne marl; of Jackson Eocene age.

\section{Cypraea sp. $d{ }^{\circ} \cdot$ \\ Plate V, Figures 11-12}

Cast small, globose, subcircular in marginal outline; aperture moderately narrow and regularly denticulated on right and left lips, canaliculate at anterior extremity; spire enveloped, apex forms a cup-shaped depression, exhibiting the volutions, in the center of which the nuclear tip appears a little elevated; surface smooth. Sculpture of shell unknown.

Height, 14 millimeters; maximum diameter, 12.5 millimeters.

This form resembles C. problematica Heilprin in the cup-shaped depression of its apex, exhibiting the nuclear tip at the center. Itris; however, much less elongated than that species."

Localities: Wilmington, New Hanover 'County; old Rocky Point, Pender County, N. C.

Geologic horizon: Castle Hayne marl, of Jackson Eocene age.

$$
\begin{gathered}
\text { Cypraea sp. } e \\
\text { Plate V, Figure } 13
\end{gathered}
$$

Cast of moderate size, somewhat elongated, oval in marginal outline; aperture narrow, canaliculate at anterior extremity; spire closely enveloped, deeply sunken; surface of cast smooth. Sculpture of shell unknown. Height 25 millimeters; maximum diameter above the middle, 17 millimeters.

Locality: old Rocky Point, Pender County, N. C.

Geologic horizon: Castle Hayne marl, of Jackson Eocene age.

\section{Family CASSIDIDAE \\ Genus CASSIS Lamarck \\ Cassis? sp. \\ Plate V, Figures 14-15}

A single incomplete cast of a Cassis is in the United States National Museum collection from Wilmington, N. C.

Cast small, plump, volutiform; three and one-half whorls present; spire low; body whorl three-fourths 
of height of shell; early whorls smooth; basal whorl sculptured with slightly raised, widely spaced parallel spiral lines and indistinct growth lines; sutures of cast distinct, impressed. Aperture of shell unknown. Dimensions of figured broken specimen: Height, 18 millimeters; maximum diameter, 11.5 millimeters.

In general appearance this form is much like Semicassis nuperus (Conrad). The internal cast of that species, however, is smooth and does not reflect the exterior sculpture.

Locality: Wilmington, New Hanover County, N. C.

Geologic horizon: Castle Hayne marl, of Jackson Eocene age.

\section{Subgenus PHALIOM Linck \\ Phaliụm sp. \\ Plate V, Figure 16}

Internal cast small, globose, with short spire preserving three whorls; exhibiting three varices behind the lip, which is destroyed; siphonal notch narrow, slightly recurved; canal broken; surface of cast smooth. Dimensions of cast with apex and anterior canal broken: Height, 23 millimeters; maximum diameter, 16 millimeters.

This species is apparently related to Phalium globosum Dall, from the upper Eocene of Mississippi, the Ocalr limestone of Florida, and the Chipola formation of Florida. The North Carolina cast, however, is narrower and has no carina along the whorls, which are more rounded.

Locality: Old Rocky Point, Pender County, N. C.

Geologic horizon: Castle Hayne marl, of Jackson Eocene age.

\section{Superfamily RACHIGLOSSA \\ Family BUCCINIDAE \\ Genus PTychosalPINX Gill}

Ptychosalpinx sp.

Plate V, Figure 17

Cast of medium size, subfusiform, with rather short, pointed spire and about four whorls; whorls enlarged rapidly, basal whorl forming nearly two-thirds of total height; sutures distinct but not deeply impressed; aperture wide; surface of cast smooth except for faint axial growth lines. Height, 33 millimeters; maximum diameter, 20 millimeters.

This species is similar to Buccinum porcinum Say, from the Miocene of Petersburg, Va. The whorls of the Miocene form are slightly constricted at the top, and the outer lip is characterized by distinct lirae on the inside.

$$
51278-26 \uparrow-3
$$

Locality: Old Rocky Point, Pender County, N. C. Geologic horizon: Castle Hayne marl, of Jackson Eocene age.

\author{
Family FASCIOLARIIDAE \\ Genus FUSINUS Rafinesque \\ Fusinus abruptus (Tuomey)? \\ Plate VI, Figure 1
}

Fusus abruptus Tuomey, Acad. Nat. Sci. Philadelphia Proc., vol. 6, p. 193,1852 .

The original description of this species is as follows:

Ovoid; whorls rounded, ventricose, the last one terminating abruptly in the canal. Dimensions: Spiral angle, $70^{\circ}$; height, 6 inches; breadth, 4 inches.

Tuomey described this species from a cast collected from the Eocene at Wilmington, N. C. It has not been figured. The writer's specimens from the type locality are not complete but appear to be longer and to have a much smaller apical angle than the one described by Tuomey. However, the casts occur abundantly at Wilmington and are the only large Fusus-like forms in the fairly large collection from this locality in the United States National Museum. With the meager description and no figure given it is impossible to be certain of the identification. It is ' believed, nevertheless, that this form is the Fusus abruptus of Tuomey.

Cast of two and one-half whorls, large, spirally coiled; whorls ventricose, flattened or slightly constricted above the middle; volutions distant indicating a very distinct suture in the shell; basal whorl projected forward in a canal of unknown length. Dimensions of cast of two and one-half whorls with anterior canal broken: Height, 167 millimeters; maximum diameter, 107 millimeters.

Locality: Wilmington, New Hanover County, N. C.

Geologic horizon: Castle Hayne marl, of Jackson Eocene age.

\section{Fusinus sp.}

Plate VI, Figure 2

Cast of medium size, with high spire, loosely coiled, and about four whorls; whorls inflated; aperture oval; length of anterior canal unknown; surface of internal cast smooth. Dimensions of cast of three whorls with anterior canal broken: Height, 37 millimeters; maximum diameter, 21 millimeters.

This form is similar in shape to Fusinus abruptus Tuomey, described above. It is very much smaller and more loosely coiled, however, and the whorls are not constricted toward the top, as in Tuomey's species.

Locality: Wilmington, New Hanover County, N. C.

Geologic horizon: Castle Hayne marl, of Jackson Eocene age. 


\section{Family TURBINELLIDAE}

Genus TURBINELLA Lamarck

Subgenus VASUM (Bolten) Link

Vasum wilmingtonense Brown and Pilsbry

Vasum wilmingtonense Brown and Pilsbry, Acad. Nat. Sci. Philadelphia Proc., vol. 64, p. 153, 1912.

The original description of this species is as follows:

This form is represented by an internal cast wanting the apical whorls, apparently derived from a species shaped like $V$. haitense. The conic spire diverges at an angle of about $80^{\circ}$, the crown of each whorl being narrowly rounded. The last whorl is much less convex above, being somewhat flattened and sloping to the rounded shoulder. The periphery, viewed from above, is polygonal; the last three angles on the last half whorl are prominent, but several on the first half are barely perceptible. Below the shoulder the sides taper to the narrow base, are a little swollen midway and contracted below the shoulder and near the base. Four deep furrows indicate as many stout columellar folds in the shell, the lowest one being somewhat smaller. The length of the cast is 113 millimeters, and the greatest diameter 66 millimeters.

In the absence of information as to the stratigraphic position of the specimens, we can not say whether this species occurred with the preceding Eocene forms or, as seems more likely, in an overlying bed.

Several broken casts of Vasum wilmingtonense from the type locality are in the United States National Museum. It is the writer's opinion that this species comes from the Eocene deposits, like the other forms listed with it by Brown and Pilsbry. The overlying formation at the City Rock quarry, east of Wilmington, is Miocene. These beds are highly fossiliferous and have yielded a large fauna of perfectly preserved mollusks. $V$. wilmingtonense has never been found in these overlying beds, and with the large collections at hand it is reasonable to infer that it does not occur in them. Practically all of the Eocene fauna at Wilmington is preserved only in casts, and the matrix of this form appears to be identical with that of the known Eocene forms.

Locality: Wilmington, New Hanover County, N. C.

Geologic horizon: Castle Hayne marl, of Jackson Eocene age.

\section{Family. MARGINELLIDẠE \\ Genus MARGINELLA Lamarck \\ Marginella sp. \\ Plate V, Figure 18}

Internal cast moderately large, involute, subconic to ovoid; aperture as long as shell, narrow, slightly arcuate, widening toward the base; outer lip of shell internally crenulate, in some specimens with about 20 lirae; inner lip with seven plaits, which become stronger and oblique anteriorly; apex of cast depressed with an apical, cup-shaped depression, exhibiting the volutions, in the center of which the nucular tip appears a little elevated. Surface of cast smooth.
Height, 20 millimeters; maximum diameter, 11 millimeters.

The cast here described can not be distinguished from Marginella larvata Conrad, from the Gosport sand of the Claiborne group of Alabama. No casts of that species are available, but in every point where the casts of the North Carolina form can be compared with the perfect shell of $M$. larvata they appear to be identical.

Localities: Old Rocky Point, Pender County; Wilmington, New Hanover County; 10 miles northwest of Jacksonville, Onslow County, N. C.

Geologic horizon: Castle Hayne marl, of Jackson Eocene age.

\section{Family VOLUTIDAE \\ Genus MITRA Lamarck \\ Mitra sp. $a-f$ \\ Plate V, Figures 19-24}

Internal casts of Mitra-like forms occur abundantly in the Eocene deposits at Wilmington and Rocky Point, N. C. By a careful comparison of these forms the writer has been able to distinguish six distinct species. All of them are similar in appearance and may be described in general as elongated, slender, involute casts with high tapering spire above a relatively large body whorl. The aperture is in general lens-shaped, tapering to a point posteriorly and broadly canaliculated anteriorly. On the inner lip inclined columellar plaits are more or less strongly developed.

Species $a$ is characterized by a high body whorl with straight sides and with the columella turned to the left anteriorly.

Species $b$ differs from species $a$ in the greater height of the whorls above the body whorl and in having the columella practically straight.

In species $c$ the sides of the basal whorl are slightly arcuate, instead of straight, the whorls above the body whorl are noticeably shorter, and the aperture is wider than in species $a$ and $b$.

Species $d$ is very similar to species $c$ but is distinguished from it by a narrower aperture, by more distinct columellar plaits, which are less inclined from the horizontal, and by a thicker columella in the shell causing in the cast a wide anterior opening in which the plaits are exposed.

Species $e$ is represented by a single imperfect cast that is broader in proportion to the length than the forms described above. The body whorl is bulbous near the top and tapers rapidly toward the anterior canal. The aperture is moderately wide.

In species $f$ the columella of the shell is very small and twisted to the left so that in the cast the anterior opening is small and only the ends of the lower plaits 
are visible. The body whorl is moderately inflated with arcuate sides curving gracefully at the anterior end to form; the canal.

One or two other Mitra-like forms are included in the collection, but they are so fragmentary that their description would be of no value.

\section{Genus PLEJONA Bolten}

Plejona cf. P. petrosus (Conrad)

Plate VI, Figure 3

Cast conic, with low spiral; body whorl angulated near the top, with from eight to ten low nodes along the shoulder; earlier whorls also angulated and with faint nodes; aperture moderately narrow and of uniform width, canaliculated anteriorly; inner lip with two or three prominent plaits and numerous. faint lirac. Sculpture of shell unknown. Dimensions of cast of two and one-half whorls with part of spire missing: Height, 29 millimeters; maximum diameter, 16.5 millimeters.

Locality: Wilmington, New Hanover County, N. C. Geologic horizon: Castle Hayne marl, of Jackson Eocene age.

\section{Plejona conoides (Tuomey)?}

Plate VI, Figure 4

Voluta conoides Tuomey, Acad. Nat. Sci. Philadelphia Proc., vol. 6, p. 193, 1852.

Tuomey's specimen was not figured, and the description is very brief, as follows:

Conical; spire short; whorls four, columellar plaits numerous. Resembles Conus gyratus. Dimensions: Spiral angle, $87^{\circ}$; height, 2 inches; breadth, 1 inch.

The single specimen in the writer's collection is, like the type, a cast and comes from the type locality. It agrees with Tuomey's description. The sides of the outer whorl are slightly convex longitudinally. Along the rounded shoulder of the whorls are faint, closely spaced nodes. Anterior columellar plait prominent, posterior plaits numerous and less elevated; columella straight. Exterior sculpture unknown. Dimensions of cast of two and one-half whorls with spire and anterior canal incomplete: Height, 30 millimeters; maximum diameter, 21 millimeters.

This species differs from Plejona cf. P:' petrosus Conrad, described above, in the nonrounded shoulder and the closer spacing of the nodes along it. Plejona sayana (Conrad), from the Gosport sand of the Claiborne group, is similar to $P$. conoides but has more sloping shoulders and three prominent columellar plaits instead of one.

Locality: Wilmington, New Hanover County, N. C. Geologic horizon: Castle Hayne marl, of Jackson Eocene age.
Genus SCAPHELLA Swainson

Scaphella (Eucymba) ocalana Dall?

Eucymba ocalana Dall, Wagner Free Inst. Sci. Trans., vol. 3, pt. 1, pp. 81-82, pl. 7, fig. 1, 1890.

Dall gives the following description:

Shell shaped like Fulgur when young, with a slender, long canal and fig-shaped body; the adult subglobular, large; nucleus lenticular, large, laterally bent, secondary; axis straight, with four sharp, elevated plaits; shell thin, unsculptured, without superimposed glaze; spire short, the early whorls spirally striate; outer lip simple, thin, arched forward toward the middle, receding somewhat at the suture, which is distinct, but not channeled.

The single specimen of this species from North Carolina is very much smaller than the young form figured by Dall. It is, like the type, a cast and appears to be identical with it in every way except in size. Dimensions of cast with anterior canal broken: Height, 8.8 millimeters; maximum diameter, 5.8 millimeters.

Locality: Old Rocky Point, Pender County, N. C.

Geologic horizon: Castle Hayne marl, of Jackson Eocene age.

\section{Genus CARICELla Conrad Caricella? sp. \\ Plate VII, Figure 1}

Cast volute, inflated, with low spire; body whorl with rounded shoulder and shallow, longitudinal grooves indicative of coarse growth lines in the shell; aperture broadly lenticular and canaliculate anteriorly; inner lip with four prominently elevated, inclined plaits. Dimensions of cast of two whorls with spire missing: Height, 31 millimeters; maximum diameter, 23 millimeters.

This species is similar to casts of Caricella from the Richards quarry, Ocala, Fla. It differs from the Florida species in having the sides more arcuate, the aperture broader, and four columellar plaits instead of five. It may be compared with $C$. doliata, from the Gosport sand of the Claiborne group, which seems to have a slightly lower spire and a smoother interior than the casts of the North Carolina species would indicate.

Localities: Wilmington, New Hanover County; old Rocky Point, Pender County, N. C.

Geologic horizon: Castle Hayne marl, of Jackson Eocene age.

\section{Superfamily TOXOGLOSSA Family CONIDAE Genus CoNuS Linné \\ Conus mutilatus Tuomey? \\ Plate VII, Figures 2-3}

Conus mutilatus Tuomey, Acad. Nat. Sci. Philadelphia Proc., vol. 6, p. 193, 1892.

Conus mutilatus has never been figured and Tuomey's description of the cast, given below, is not complete. 
Spire depressed; whorls flattened; side longitudinally convex. Spiral angle, $101^{\circ}$; height, 2.5 inches; breadth, 1.5 inches. Casts of shell are abundant at Wilmington, N. C., and in the white limestone of Alabama. It is also found in the Eocene beds on the Santee. They are easily distinguished from the other Eocene species. In C. gyratis Morton the spire is more produced; whilst in $C$. sauridens Conrad it is more depressed. Casts of the latter have the spiral whorls in nearly the same plane.

Numerous specimens of various sizes from the type locality are in the United States National Museum. The casts have about five whorls; spire elevated with flattened apex; top of whorls depressed parallel to the sides of apical angle; sutures of cast deeply channeled; aperture narrow, curving slightly to the left at base. Height, 23 millimeters; maximum diameter, 14 millimeters.

Conus mutilatus has a higher spire than $C$. sauridens Conrad, and shows no signs of a fold or the columella. C. mutilatus is similar to casts of Conus collected by Heilprin from the Eocene of South Carolina, which are in the United States National Museum labeled C. gyratus? Morton but are obviously not that species. C. mutilatus differs from the South Carolina form in its higher spire and less deeply channeled sutures.

Localities: Wilmington, New Hanover County; old Rocky Point, Pender County, N. C.

Geologic horizon: Castle Hayne marl, of Jackson Eocene age.

\section{Conus? sp.}

Plate VII, Figure 4

Cast is similar to Conus mutilatus Tuomey, described above, but has a more elevated spire, with the apex rising regularly to a point. Maximum diameter of cast with anterior portion missing, 12 millimeters.

Locality: Old Rocky Point, Pender County, N. C.

Geologic horizon: Castle Hayne marl, of Jackson Eocene age.

\section{Class CEPHALOPODA}

\section{Genus ATURIA Bronn}

\section{Aturia alabamensis (Morton)}

Nautilus alabamensis. Morton, Synopsis of the organic remains of the Cretaceous group, p. 33, pl. 18, fig. 3, 1834.

Morton briefly describes this species as follows:

Shell suboval, compressed; septae profoundly sinuous; siphuncle very large. Length, 10 inches; height, 9 inches; greatest diameter, $4 \frac{1}{2}$ inches. From the newer Cretaceous rock (Eocene) near Claiborne, Ala.

Aturia alabamensis occurs abundantly in the Eocene sediments of North Carolina. It is preserved only in the form of casts of the interior of the shell, but these retain perfectly the form of the septa, sutures, siphuncle, etc. Individuals range in size from small ones up to some 8 inches in longest diameter.

The cast is suboval, closely convolute, with closed umbilicus; sides depressed, convex, and dorsum smoothly rounded. The inner volution projects into the aperture of the outer one, about one-third of the distance from the umbilicus to the outer margin. The septa are somewhat closely arranged and number about 13 in the last coil of the shell; sutures rising from the umbilical depression make a broad curve forward to a point about the middle of the volution, thence curving abruptly toward the posterior in a long pointed spur, the outer side of which is nearly straight and parallels the margin of the dorsum. From the anterior limit of the spur the suture passes directly across the dorsum. The septa are strongly concave, bending posteriorly around the siphuncle to form a round funnel-shaped depression; siphuncle moderately large, round, and situated, in all the specimens the writer has seen, very close to the venter of the next inner volution. The surface of the shell is unknown.

Dimensions of large perfect cast in collection of Johns Hopkins University: Longest diameter, 6 inches; shortest diameter, $4 \frac{3}{4}$ inches; thickness, $23 / 4$ inches.

Aturia alabamensis is closely related to $A$. vanuxemi Conrad, from the Eocene layers of the upper bed of the greensand marls of New Jersey. The general contour of the shell and the striking shape of the sutures are almost identical. A. alabamensis, however, is not nearly so compressed laterally, and the funnel-shaped depression in the septa around the siphuncle is round and not so large as in A. vanuxemi.

Localities: Wilmington, New Hanover County; old Rocky Point, Pender County, N. C.

Geologic horizon: Castle Hayne marl, of Jackson Eocene age.

\section{Genus EUंTREPHOCERAS Hyatt}

Eutrephoceras carolinensis Kellum, n. sp.

Plate VII, Figures 5-7

This species has been found in North Carolina only as casts. Shell strongly globose in form, varying in size, largest specimens 65 millimeters in diameter. Aperture large, transverse; venter curved; cross section of the volution nearly semicircular; umbilicus. deep, with moderately abrupt margin; sutures cross. the venter in an almost straight line, making a slight curve anteriorly before entering the umbilicus; septa moderately distant and deeply concave; siphuncle small, round, subcentral in position. Surface of shell unknown:

Eutrephoceras carolinensis is very similar to $E$. perlatus Morton, from the Cretaceous of Alabama, and to $E$. dekayi Morton, from the Cretaceous of $\mathrm{New}$ Jersey. In fact, it has been called dekayi by some collectors. It is here separated from the Cretaceous. species on account of the essential straightness of the sutures across the venter. The sutures of both perlatus and dekayi possess a very definite "backward sinus on the middle of the back." $E$. carolinensis is 
very abundant in the Castle Hayne marl of North Carolina.

Localities: Wilmington and Castle Hayne, New Hanover County; old Rocky Point, Pender County, N. C.

Geologic horizon: Castle Hayne marl, of Jackson Eocene age.

\section{Class BRACHIOPODA}

\section{Family RHYNCHONELLIDAE}

\section{Genus RHYNCHONELLA Fischer de Waldheim}

\section{Rhynchonella salpinx Dall}

Rhynchonella salpinx Dall, Wagner Free Inst. Sci. Trans., vol. 3, pt. 6, p. 1535, 1903 .

The following is Dall's discussion of this species:

Eocene limestone of the city quarry, Wilmington, N. C.; Vaughan.

Shell small, rounded trigonal, smooth behind, plicate anteriorly; ventral valve with a prominent, acute, hardly recurved beak, with a small peduncular foramen, $* * *$ the deltidial plates approach each other to form an arch, unite in the median line, and project with flaring edges distally, thus forming a tube in which the peduncle is inclosed and to which the beak of the ventral valve contributes a relatively small portion. This arrangement is so different from that which obtains in Hemihyris that I hesitate to include the species under that name but, since the internal characters are not accessible, prefer to list it under Rhynchonella until more information shall be obtainable. * * * Hinge-line somewhat flexuous, anterior margin of the valve with a broad double fold produced haemally, with two or three less pronounced plications laterally; haemal valve convex, reciprocally plicate; interior filled with a hard matrix; shell structure fibrous. Length, 11 ; breadth, 9.5 ; dorsoventral maximum diameter, 6 millimeters.

This pretty little species appears to be rare, as only two specimens were obtained.

Dall's description is very complete. The writer has four additional specimens of this species from the type locality. One is much larger than Dall's type: Length, 14 millimeters; width, 15 millimeters; thickness, 8 millimeters.

Geologic horizon: Castle Hayne marl, of Jackson Eocene age.

\section{Rhynchonella holmesii Dall}

Rhynchonella holmesii Dall, Wagner Free Inst. Sci. Trans., vol. 3, pt. 6, p. 1536, 1903 .

Dall's description of this species follows:

Eocene limestone of the city quarry, Wilmington, N. C.; Vaughan.

Shell small, rounded trigonal when young, much móre transverse when adult, smooth near the beaks, plicate in front and over most of the valves; the ventral valve with a small, erect beak with a moderate foramen, the deltidial plates united in front of it; anteriorly the margin is slightly convexly flexuous, the valve evenly, uniformly, radially sculptured with 12 to 14 subequal rounded ribs with narrower interspaces; haemal valve more convex, reciprocally plicate; the ventral valve has no median septum, but the presence of a hard matrix prevents inspection of the interior characters. Length of haemal valve of an adult, 9.5 ; breadth, 11 ; diameter, 5 millimeters; of a ventral valve, length, 10.5 ; breadth, 11.5; diameter, 3 milli . meters.

The specimen figured is a young shell, the adults being more or less fragmentary. It is named in honor of Dr. F. S. Holmes, to whom are chiefly due the fine monographs on the postMiocene fauna of South Carolina.

Geologic horizon: Castle Hayne marl, of Jackson Eocene age.

\section{Family TEREBRATULIDAE Genus TEREBRATULA Muller}

Terebratula wilmingtonensis Lyell and Sowerby

Terebratula wilmingtonensis Lyell and Sowerby, Geol. Soc. London Quart. Jour., vol. 1, pp. 431-432, 1845.

Terebratula canipes Ravenel, Acad. Nat. Sci. Philadelphia Proc., vol. 2 , p. 97, 1844.

Conrad, Am. Jour. Conchology, vol. 1, p. 15, 1865.

Rhynchonella wilmingtonensis Conrad, Am. Jour. Conchology, vol. 1, p. 35, 1865.

Terebratula demissirostra Conrad, in Kerr, Report of the geological survey of North Carolina, vol. 1, p. 18, pl. 3, fig. 1, 1875.

Lyell's original discussion and description of this species is as follows:

This shell resembles most nearly in general form $T$. uva Broderip (recent from the Gulf of Tehuantepec) and also approaches T. bisinuata Lamarck, a fossil of the Paris Basin. The following are its characters: Terebratula with an oblong, smooth shell, posteriorly acuminated, anterior margin nearly even, dorsal valve large, and posteriorly prominent.

Conrad figured this same form and described it under the name $T$. demis sirostra in Kerr's report on North Carolina (1875) as follows:

Shell ovate, inflated, with five short plications, lateral pliae widest; valves nearly equally ventricose, the smaller valve least so and regularly arched in outline; tip of the beak of larger valve acute and curved downward nearly to the summit of the opposite valve; foraminal area very oblique.

Locality: Wilmington, N. C.; Prof. Kerr.

Prof. Kerr informs me that this species was found embedded in a whitish Eocene limestone near Wilmington. The pendent angle of the rostrum is a striking character of the shell.

Terebratula wilmingtonensis is characterized by a thin shell with very reduced teeth and is remarkably variable in form. An examination of a large number of individuals from the type locality shows a complete gradation between the extremes of differentiation. The species ranges from very small forms up to some 45 millimeters in length. In very young individuals the valves are generally flattened or slightly convex and smooth; the anterior portion is subcircular in outline; lateral margins are nearly straight toward the posterior, forming an acute angle at the apex of the beak; ventral beak slightly incurved over the cardinal area, which is nearly perpendicular to the plane of the foramen; area very small, curved, plated, and subtriangular in outline, with apex of posterior angle truncated by the foramen; foramen large, circular, with plane of circumference inclined to the 
plane between the valves. With increasing size the shell develops a great diversity of form; the smooth, flattened, pellet shape may be retained in the adult; more frequently, however, the valves become greatly inflated and develop waves or plications toward the anterior margin. These plications may be very few in number and shallow, or numerous, deeply folded, and angular, giving the anterior margin of the valves a sawtooth appearance.

The development of such folds greatly strengthens the shell and prevents rotation of the valves. The surface of the shell remains unsculptured except for the development of the anterior plications and concentric growth lines of varying intensity. The most characteristic and persistent feature of $T$. wilmingtonensis is the long, straight right and left margins of the shell, which extend posteriorly from the anterior margin, forming an acute angle at the beak. This feature is best developed in elongated individuals and least conspicuous in abbreviated and more rounded specimens. It is correlated with a flattened area along the inclined sides of both valves. Dimensions of large, typically developed shell: Length, 38 millimeters; breadth, 27 millimeters; thickness, 25 millimeters.

Localities: Wilmington and $31 / 2$ miles northeast of Wrightsboro, New Hanover County; old Rocky Point and Northeast Cape Fear River 31/2 miles above Castle Hayne Bridge, N. C.

Geologic horizon: Castle Hayne marl, of Jackson Eocene age.

\section{Terebratula crassa Kellum, n. sp. \\ Plate VII, Figures 8-13}

Test of medium size, ovate, rostrate, smooth; ventral valve strongly inflated and very thick posteriorly, causing the interior of the shell in that region to be very constricted; hinge teeth prominent and thick; beak full, short, curving downward and abruptly truncated at the apex by a large foramen, which is strongly excavated at the opening through the thickness of the shell; cardinal area small, triangular, truncated by the foramen, slightly concave, and covered by numerous rectangular plates. The dorsal valve is much less inflated than the ventral. It is thick posteriorly and thins toward the anterior; cardinal process prominent; dental sockets deep; hinge plates prominent; muscular impressions distinct. Dimensions of figured fragments: Ventral valve, length, 25 millimeters; width, 24 millimeters; dorsal valve, length, 26 millimeters; width, 24 millimeters.

Terebratula crassa is closely related to T. wilmingtonensis. Its principal points of difference are the heavy, prominent hinge teeth and the pronounced posterior thickening of the shell. The anterior portion of this species must be extremely fragile, as it is missing in every one of the 25 specimens which the writer has at hand.
Locality: 5 miles west of Pink Hill, Duplin County, N. C.

Geologic horizon: Castle Hayne marl, of Jackson Eocene age.

\section{Genus TEREBRATULINA D'Orbigny}

Terebratulina lachryma (Morton)

Terebratula lachryma Morton, Synopsis of the organic remains of the Cretaceous group, p. 72 , pl. 10, fig. 11; pl. 16, fig. $6 ; 1834$.

Terebratulina lachryma Conrad, Am. Jour. Conchology, vol. 1, p. 15, 1865.

Morton's description of this species follows:

Ovato-triangular; beak elongated, foramen large; valves convex, marked by delicate longitudinal striae. Length, half an inch; breadth, one-fourth of an inch.

This beautiful species is abundant in the calcareous strata of South Carolina, whence I received it through Mr. Conrad. This gentleman has more recently obtained it from the same strata below Claiborne, Ala.

Morton's brief description may be supplemented by characterizing $T$. lachryma as a very small, delicate shell with depressed form and lens-shaped cross section perpendicular to the plane between the valves. The marginal outline of small specimens is distinctly oval, with an acute angle at the beak; larger and more inflated individuals are subcircular, with an obtuse angle at the beak. The ventral beak, with large foramen, curves downward over an extremely small false cardinal area. Surface of both valves sculptured with concentrio growth lines and fine radial striae, faintly cancellated. Length, 11 millimeters; width, 8.5 millimeters; thickness, 5.5 millimeters.

Locality: Wilmington, New Hanover County, N. C.

Geologic horizon: Castle Hayne marl, of Jackson Eocene age.

\section{SYSTEMATIC PALEONTOLOGY OF THE TRENT MARL} Phylum MOLLUSCA

Class PELECYPODA

Order PRIONODESMACEA

Family ARCIDAE

Genus ARCA (Linné) Lamarck

$\because \quad \begin{aligned} & \text { Arca (Scapharca) silverdalensis Kellum, n. sp. } \\ & \\ & \cdots\end{aligned}$

Shell small, short, rostrate, with low, mesially sulcate, prosocoelous beaks; anterior margin straight at juncture with hinge, curving gently into the ventral margin, which is slightly convex; posterior margin slightly produced, straight, and forming an obtuse angle with the hinge line; ribs 22 to 25 in number, prominent, rounded to squarish in cross section, ornamented with blunt tubercles, best developed on 
anterior ribs; interspaces channeled, equal in width to the ribs, normally ornamented with equally spaced, concentric lines. Posterior slope slightly concave and separated from the medial portion of the shell by a distinctly angulated posterior ridge, which extends from the umbo to the base of the posterior margin. The area is marked by three $V$-shaped furrows, which are usually faint toward the anterior. The hinge line is very slightly curved, with numerous teeth that are small and vertical beneath the beaks, but become larger and somewhat inclined distally. Inner margin of shell is beveled and strongly fluted. Length, 16 millimeters; height, 11 millimeters; depth of left valve, 5 millimeters.

Arca silverdalensis is distantly related to the Vicksburg. species $A$. lesueuri Dall. That species has double, granulated ribs on the left valve, higher beaks that do not have a medial sulcation, and a less angulated posterior ridge. The Silverdale species is distinguished from young specimens of $A$. staminata Dall, a common form in the Chipola formation of Florida, by its lower beaks, smaller number of ribs, more produced posterior margin, and the sharper angle of the posterior ridge. It does not attain the size of the adult $A$. staminata. Young individuals of $A$. carolinensis Wagner, from the Miocene of Duplin County, N. C., strongly resemble this form. They are distinguished by their shorter anterior-posterior dimension, greater number of ribs, and a more rounded postumbonal ridge.

Locality: Silverdale, Onslow County, N. C.

Geologic horizon: Trent marl, of lower Miocene age.

\section{Genus GLYCYMERIS DaCosta}

Glycymeris anteparilis Kellum, n. sp.

Plate VIII, Figures 4-6

Shell orbicular, convex, moderately large, equivalve, and nearly equilateral; beaks prominent, well inflated, and overturned above a broad triangular area with five or six deep, chevron-shaped ligament grooves; hinge line variable, usually with fine vertical teeth beneath the beaks, becoming larger, slightly curved, and horizontal distally; adductor muscle scars on slightly raised platforms; inner margin coarsely crenu1ate. The exterior of all specimens in the collection is worn smooth but shows faint traces of radial sculpture crossed by irregular, concentric lines of growth. Dimensions of figured fragment with broken margin: Height, 53 millimeters; breadth, 51 millimeters.

This species is closely related to Glycymeris parilis Conrad, from the Miocene of Maryland. If differs from that species by the higher and more inflated beaks and the deep chevron-shaped ligament grooves.

Locality: Silverdale, Onslow County, N. C.

Geologic horizon: Trent marl, of lower Miocene age.
Glycymeris sp.?

Plate VIII, Figure 7

Internal cast large, profoundly inflated, subcircular in marginal outline, equilateral; beaks of medium elevation; teeth long, thin, and parallel to the hinge line even in young individuals; platform of adductor muscles deeply impressed on cast; distal margin strongly fluted. The exterior sculpture is unknown. Dimensions of large individual: Length, about 56 millimeters; height, 56 millimeters; depth of single valve, about 18 millimeters.

This species is abundant locally in the hard impure limestone along Trent River. In every specimen the shell material is entirely dissolved, leaving the perfect mold in the porous matrix.

Locality: Trent River about 3 miles downstream from Polloksville, Jones County, N. C.

Geologic horizon: Trent marl, of lower Miocene age.

\section{Family PECTINIDAE \\ Genus PECTEN Muller \\ Pecten elixatus Conrad?}

Pecten elixatus Conrad, Acad. Nat. Sci. Philadelphia Proc., vol. 2, p. 174, 1846.

Pecten elixatus Conrad? Harris, Bull. Am. Paleontology, vol. 8, No. 33, pp. 15, 16, pl. 2, figs. 10, 11, 1919.

This species is not in the collections of the United States National Museum. The following is Harris's discussion:

A few fragments of another species of Pecten were found among the representatives of the species just described ( $P$. trentensis Harris) which seem at first sight to belong to $P$. poulsoni. But upon direct comparison of the two the left valve of poulsoni is never flat and in some instances decidedly gibbous, whereas in this species the fragment figured indicated a plane or even concave valve. Again, the ribs on the posterior ear are much more numerous in this North Carolina species, and the posterior cardinal angle less than $90^{\circ}$. The tops of the ribs in poulsoni appear broad and tripartite; in this species, bipartite. The concentric sculpturing is much the same in both species. However, a large series of these forms may cause them to be finally regarded as one species. If so, it would seem that a considerably greater geologic range should be given to this species than has been admitted heretofore, else the horizon on the Trent whence these specimens came is far higher than has been suspected. A rather near relative of poulsoni has been described by Dall as burnsii, from the Chipola marls of Florida (Trans. Wag. III, 1898, p. 720, pl. 34, fig. 8). Conrad's elixatus, from "near Santee Canal, South Carolina, in white, friable limestone," is generally referred to poulsoni Morton.

\section{Pecten trentensis Harris}

Pecten trentensis Harris, Bull. Am. Paleontology, vol. 8, No. 33, p. 15,1919 , pl. 2 , figs. 8,9 .

This species is not in the collections of the United States National Museum. The following is Harris's description:

Form and size as indicated by the illustrations; ribs highly variable in number, size, and amount of ornamentation; gen- 
erally bifid and generally ornamented by highly raised, scalelike or imbricating concentric lines; costation showing a strong tendency toward a tri- or quinque-costate pattern, especially in the left valve; central rib largest of the three or five major ones.

The general appearance of this shell is so different from anything we have heretofore found in the Eocene of this part of the United States that, owing to a lack of well-known species from the same locality, its horizon must at present be considered as doubtful.

Type and specimens figured deposited by G. D. Harris. in museum at Cornell University.

Locality: Found in light marly bed, right bank of Trent River near the water's edge, about 6 miles below Pollocksville, N. C., in the so-called Trent formation. The latter has been referred to the upper Claiborne or Jackson Eocene.

\section{Family SPONDYLIDAE}

\section{Genus PIICATULA Lamarck}

\section{Plicatula densata Conrad}

Plicatula densata Conrad, Acad. Nat. Sci. Philadelphia Proc., vol. 1, p. 311, 1843; Fossils of the medial Tertiary of the United States p. 75 , pl. 43, fig. 6, No. 3, 1845; Acad. Nat. Sci. Philadelphia Proc., vol. 14, p. 582, 1863.

Dall, Wagner Free Inst. Sci. Trans., vol. 3, pt. 4, p. 763, 1898.

Spondylus inornatus Whitfield, Mollusca and Crustacea of the Miocene formations of New Jersey: U. S. Geol. Survey Mon. 24, p. 34, pl. 5, figs. 1, 2, 1894.

In 1843 Conrad described this species as follows:

Ovate, thick, profoundly and irregularly plicated; inferior valve ventricose; ribs acute, with arched spiniform scales; cardinal teeth large, curved, laterally striated, crenulated on the margins; larger cardinal tooth in each valve slightly bifid, broad; muscular impression prominent. $* * *$ The valves have about ten folds, and the lower valve closely resembles a variety of Ostrea virginiana.

This species is extremely variable and has been reported from widely separated horizons on the east coast. The following localities and horizons have been listed by Dall: ${ }^{33}$

Oligocene of the Peninsular limestone of Archer, Fla., and the Nummulitic horizon at Ocala, Fla.; Dall and Willcox; of the Tampa silex beds at Ballast Point; the Chipola marls of Calhoun; of the lower bed at Alum Bluff on the Chattahoochee River, and of the Oak Grove sands, Santa Rosa County, Fla.; also of the Bowden beds of Jamaica, West Indies, and the Guallava beds of Costa Rica. Also in the lower Miocene marls of Cumberland County, N. J., at Shiloh and Jericho.

Locality: Silverdale, Onslow County, N. C.

Geological horizon: Trent marl, of lower Miocene age.

\section{Order TELEODESMACEA}

Family ASTARTIDAE

\section{Genus ASTARTE Sowerby}

Astarte onslowensis Kellum, n. sp.

Plate VIII, Figures 8-10

Shell small, subtrigonal, nearly equilateral, with pointed, flattened beaks; lunule long and moderately

ə3 Dall, W. H., U. S. Nat. Mus. Bull. 90, p. 125, 1915. excavated; escutcheon long, narrow, flat, and clearly defined; sculpture of coarse, angular concentric undulations on upper third of shell, and normal concentric growth lines on lower two-thirds; hinge normal; inner margin finely crenulate; muscular impressions rather small, impressed. Length, 11.5 millimeters; height, 11 millimeters.

Astarte onslowensis is very similar to the variety of A. undulata occurring in the Duplin Miocene of North Carolina. It is somewhat narrower in the anteriorposterior dimension than the Duplin form; the undulations do not extend down so far on the disk and are more angulated; the lunule is more deeply excavated. $A$. onslowensis is readily distinguished from A. wagneri Dall, occurring in the Oak Grove sand of Florida, by its longer and less excavated lunule. The Oak Grove species is sculptured with low, rounded, concentric waves over the entire disk; the beaks are higher and not flattened. There is no form in the Vicksburg group or the Chipola formation with which this species could be confused.

Locality: Silverdale, Onslow County, N. C.

Geologic horizon: Trent marl, of lower Miocene age.

\section{Family CRASSATELIITIDAE \\ Genus CRASSATELLITES Krüger}

Crassatellites mississippiensis var. silverdalensis Kellum, n. var.

Plate VIII, Figures 11-12

Conrad ${ }^{34}$ originally described Crassatella mississippiensis from specimens found at Vicksburg, Miss., as follows:

Ovate-trigonal, inequilateral, thick and ponderous; surface coarsely striated; summits flattened, sulcated; umbo planoconvex, with numerous sulci, obsolete behind the umbonal slope, which is angulated and subcarinated above; posterior extremity truncated, direct; basal margin slightly contracted anterior to the umbonal slope; inner margin crenulated. Length 3. Common. This species is variable in outline and allied to C. tumida, of the Paris Basin.

The variety silverdalensis differs from the typical Vicksburg form principally in its thicker shell and larger size. The postumbonal slope is slightly more concave, but this seems to be a variable character in C. mississippiensis. Length, 79 millimeters; height, 64 millimeters; depth of right valve, 23 millimeters.

Locality: Silverdale, Onslow County, N. C.

Geologic horizon: Trent marl, of lower Miocene age.

\section{Family CARDITIDAE \\ Genus VENERICARDIA Lamarck \\ Venericardia nodifera Kellum, n. sp. \\ Plate IX, Figures 1-3}

Shell solid, robust, obliquely oblong, the beaks full, prominent prosogyrate, and nearly anterior; anterior side short, bluntly rounded; posterior side longer,

34 Acad. Nat. Sci. Philadelphia Jour., 2d ser., vol. 1, p. 122, pl. 13, figs. 7, 10, 1850 
slightly compressed, roundly truncate behind; sculpture of 19 to 22 radial ribs, of which the posterior five or six are smaller and less elevated than the others; anterior ribs stout, the summit articulated with small, squarish, transverse nodules; interspaces subequal to the ribs; lunule rather small and deeply incised; hinge normal; the anterior cardinal pustular, the interior margins with coarse flutings. Length, 32 millimeters; height, 29 millimeters; depth of right valve, 12 millimeters.

Venericardia nodifera is nearest to V. hadra Dall, ' from the Chipola formation of Florida. All the specimens from Silverdale are much smaller than the adult form of hadra, in which the lunule is much smaller and the beaks are more twisted and situated farther anterior. $V$. nodifera is distinguished from $V$. serricosta Heilprin, which occurs in the "silex beds" of the Tampa formation of Florida, by its shorter posterior end, more inflated valves, and more numerous and usually coarser ribs.

Locality: Silverdale, Onslow County, N. C.

Geologic horizon: Trent marl, of lower Miocene age.

\section{Venericardia (Cyclocardia) granulata Say ,}

Venericardia granulata Say, Acad. Nat. Sci. Philadelphia Jour., vol. 4 , p. 142, pl. 12, fig. 1, 1824 .

Cardita granulata Conrad, Fossils of the Tertiary formations, p. 12, pl! 7, fig. 1, 1838; Nat. Inst. Proc. Bull. 2, p. 187, 1842; Am. Jour. Sci., 2d ser. vol. 1, p. 404, 1846.

Tuomey and Holmes, Pliocene fossils of South Carolina p. 66, pl. 19, figs. 6-7, 1857.

Whitfield, Mollusca and Crustacea of the Miocene formations of New Jersey, p. 56, pl. 9, figs. 1-4, 1894.

Cardita tridentata Emmons, Report of the North Carolina geo-· logical survey, p. 302 , fig. $236 \mathrm{~A}, 1858$ (not of Say).

Actinobolus granulata Conrad, Acad. Nat. Sci. Philadelphia Proc., for 1862 , p. $576,1863$.

Venericardia (Cardiocardites) granulata Meek, Checklist of the invertebrate fossils of North America, Miocene, p. 7, 1864.

Say described this species from the Miocene of Maryland in 1824, as follows:

Suborbicular, with about 25 convex ribs, and wrinkled across; inner margin crenate. Beaks nearly central, a little prominent, curved backward; ribs granulated on the umbones, and transversely wrinkled near the base convex; apices somewhat prominent beyond the general curve of the shells; inner margin and edge crenate, cardinal teeth two. Length from the apex to the base four-fifths of an inch, breadth nearly the same. Rather proportionally longer than the decussata and more oblique.

Venericardia granulata Say has a reported range from the middle Miocene (Calvert formation) to the Pliocene. The writer has compared the Silverdale forms with those from the Maryland locality and. considers them identical.

Locality: Silverdale, Onslow County, N. C.

Geologic horizon: Trent marl, of lower Miocene age.
Family LUCINIDAE

Genus PHACOIDES Bainville

Phacoides (Pseudomiltha) nocariensis Kellum, n. sp.

Plate IX, Figures 4-5

Shell thick, of medium size, subcircular, rather compressed; beaks small, pointed, curved forward, and slightly impinging upon a much reduced, striated lunule; anterior dorsal area of medium size, distinct, very slightly depressed, and longitudinally divided by a närrow radial sulcus; posterior area long, wide, and slightly depressed; surface of shell sculptured with distinct, crowded growth lines, with faint radial striations barely visible toward the umbones; teeth obsolete; anterior adductor scar moderately elongate; posterior scar subovate; interior of disk traversed by two deep grooves, extending upward from the distal margin and uniting a short distance below and posterior to the umbo; inner margin minutely crenulated. Height, 30.5 millimeters; breadth, 31 millimeters.

Locality: Silverdale, Onslow County, N. C.

Geologic horizon: Trent marl, of lower Miocene age.

\section{Family CARDIIDAE \\ Genus CARDIUM (Linné) Bruguière \\ Cardium sp. \\ Plate IX, Figures 6-7}

Shell of medium size, inflated, equilateral, with low, well-rounded median beaks, general outline ovoid, longer than high; radial sculpture of about 40 elevated ribs of triangular section, separated by nearly equal interspaces. The ribs are coarsely raised toward the margins of the disk, becoming nearly obsolete on the umbones. The internal cast is smooth on the umbo but toward the margin shows thin, rounded radial ribs, which in some individuals extend halfway up the disk; a single lateral tooth impression on either side of beak. Dimensions of large cast: Length, 40 millimeters; height, 34 millimeters; depth of single valve, about 14 millimeters.

Locality: Trent River 12 or 13 miles upstream from New Bern, N. C.

Geologic horizon: Trent marl, of lower Miocene age.

\section{Family VENERIDAE \\ Genus VENOS (Linné) Lamarck \\ Venus gardnerae Kellum, n. sp. \\ Plate IX, Figures 8-9}

Shell small for the genus, subovate, slightly truncate behind; beaks low, flattened, and anteriorly directed over a normal lanceolate lunule; posterior dorsal area long, narrow, flattened, with less elevated sculpture 
than the disk and separated from it by a low keel; concentric sculpture of thick, elevated lamellae, which are densely crowded toward the margins, becoming regularly spaced toward the umbones; hinge with three cardinals in each valve, the posterior and middle right and the middle left are grooved or bifid; pallial line with rather long and smoothly curved sinus; anterior adductor scar distinctly impressed; interior of disk with one or two broad, radial low waves extending from the umbo to the distal margin; cavity within umbones smoothly rounded and barely extending beneath dental plate; inner margin usually smooth. Length, 53 millimeters; height, 41 millimeters; depth of right valve, 14 millimeters.

Venus gardnerae is closely related to V. halidona Dall, from the "silex beds" of the Tampa formation of Florida. The shape and sculpture of the umbo are almost identical. It differs from $V$. halidona, however, in its larger size, thicker shell, long curved sinus, and sculpture of thick lamellae crowded toward the margin. $V$. gardnerae has a superficial resemblance to $V$. plena Conrad, which is of about the same size and shape. V. plenia is more depressed, with beaks more inflated, slightly higher, and situated farther forward. The pallial sinus of $V$. plena is short and angular. $V$. gardnerce is separated from $V$. erecta, which occurs at the same horizon, by its flattened and less prominent beak. This character is usually associated with a more oval marginal outline of the shell, though that feature is rather variable. The outline of $V$. erecta tends to be more triangular.

Localities: Silverdale, Onslow County; Trent River 12 or 13 miles above New Bern, Craven County, N: C.

Geologic horizon: Trent marl, of lower Miocene age.

\section{Venus erecta Kellum, n. sp.}

Plate IX, Figures 10-12

Shell small for the genus, subtrigonal, moderately inflated, with prominent beaks curved anteriorly, over a cordate lunule; posterior dorsal area narrow, elongate, flattened, with less elevated concentric sculpture than the disk and separated from it by a low keel; concentric sculpture of thick, elevated lamellae, which are densely crowded toward the margins, becoming regularly spaced toward the umbones; hinge and teeth normal; pallial line distinct, with rather long sinus; anterior adductor impressed; interior of disk with one or two low, broad radial waves extending from the umbonal region to the distal margin; cavity within umbones smoothly rounded and barely extending beneath dental plate; inner margin smooth or finely crenulated. Length, 45 millimeters; height, 48 millimeters; depth of right valve, 14 millimeters.

This species is closely related to Venus gardnerae, from which it is distinguished by its higher and more inflated beaks, and by its usual trigonal outlines. From V. halidona Dall, of the "silex beds" of the Tampa formation of Florida, V. erecta is separated by its trigonal outline, higher and more inflated beaks, and sculpture of thick, concentric, lamellae crowded toward the margins.

Localities: Silverdale, Jacksonville, and 9 miles northeast of Jacksonville, Onslow County; Trent River 12 or 13 miles above New Bern, Craven County, N. C.

Geologic horizon: Trent marl, of lower Miocene age.

\section{Genus ANTIGONA Schumacher}

\section{Antigona (Artena) lamellacea Kellum, n. sp.}

Plate IX, Figures 13-14

Shell small, subtrigonal, with concentric feeble waves; beak rather prominent, subcentral, and curved anteriorly over a normal lanceolate lunule, defined by a sharply incised line but feebly impressed; escutcheon narrow, flat, striated, defined by an indistinct rounded keel, beyond which the concentric waves do not pass; posterior portion of disk modified by a feeble radial depresssion paralleling the keel; sculpture over the entire disk of closely set, concentric, elevated lamellae; hinge normal, anterior lateral well developed; inner margin finely crenulate. Height, 12 millimeters; length, 13.5 millimeters; depth of left valve, 4 millimeters.

Antigona lamellacea is nearest to A. shepardi Dall, from the "silex beds" of the Tampa formation of Florida. It is readily distinguished from that species by its more central beaks, less pronounced concentric waves on the disk, and sculpture of elevated lamellae.

Locality: Silverdale, Onslow County, N. C.

Geologic horizon: Trent marl, of lower Miocene age.

\section{Genus MACROCALLISTA Meek}

Macrocallista minuscula Kellum, n. sp. Plate X, Figures 1-2

Shell of medium size, inequilateral, subovate, with rather prominent beaks at the anterior fourth or nearly so; the lunule narrowly lancolate, slightly impressed, and circumscribed by a, sharply incised line; anterior margin rounded, base evenly arcuate, posterior end acutely rounded; hinge normal; pallial sinus nearly horizontal, of medium length, bluntly rounded or angularly truncate anteriorly. Shell polished and sculptured with concentric growth lines. Fully adult specimens, according to fragments obtained, reach a length of 50 millimeters. Shell rather thick, with waves over the interior of the disk. Inner cavity of valves shallow, scarcely extending beneath dental plate at the umbones. Dimensions of mediumsized individual: Length, 35 millimeters; height, 26 millimeters; depth of left valve, 7.5 millimeters. 
The typical adult form of Macrocallista minuscula is readily distinguished from M. acuminata Dall, of the Alum Bluff group of Florida, by its larger size, thicker shell, more prominent beak, and more truncated anterior and posterior margins: A single young right valve from the Silverdale locality is very close to the Alum Bluff species. The individuals from the "silex beds" of the Tampa formation of Florida that have been listed under $M$. acuminata are smaller, more truncated anteriorly, and slightly less acuminated posteriorly than the Alum Bluff forms. One left valve from Silverdale, N. C., is almost identical with the form from the "silex beds."

Localities: Silverdale and Jacksonville, Onslow County; Trent River 12 miles upstream from New Bern, Trent River 4 miles upstream from New Bern, Neuse River 9 miles northwest of New Bern, and Neuse River 12 miles northwest of New Bern, Craven County, N. C.

Geologic horizon: Trent marl, of lower Miocene age.

Macrocallista tia Kellum, n. sp.

Plate X, Figures 3-4

Shell of medium size, inflated, subtrigonal, with rather prominent beaks at anterior third, curved anteriorly over a lanceolate lunule; lunule slightly impressed and circumscribed by an indistinct line; anterior and posterior margins roundly truncate, base evenly. arcuate; posterior ridge prominent; shell polished and concentrically sculptured with irregular growth lines; hinge normal; adductor muscle scars distinctly impressed; interior of disk modified by faint, broad radial waves. Length, 23 millimeters; height, 19 millimeters; depth of left valve, 7 millimeters.

Macrocallista tia is very close to M. sobrina (Conrad), from the Vicksburg Oligocene of Mississippi. It is distinguished from that species by a flattening of the umbo, by a more angulated posterior ridge, and by the posterior cardinal tooth, which in $M$. sobrina is more nearly horizontal. Macrocallista tia is separated from $M$. minuscula, which occurs at the same horizon, by its greater inflation of the valves, by a slight flattening on the umbone, by the more angulated postumbonal ridge, and by the truncation of the anterior and posterior margins.

Locality: Silverdale, Onslow County, N.C. '

Geologic horizon: Trent marl, of lower Miocene age.

\section{Family SAXICAVIDAE \\ Genus PANOPE Menard}

Panope sp.

Plate X, Figures 5-7

Shell oblong, subovate, ventricose; anterior and posterior ends gaping; beaks low, rounded, and slightly anterior; posterior side narrowed, somewhat produced; exterior of shell with irregular, concentric, prominent lines of growth; pallial sinus long, extending slightly anterior to the beaks.

The writer has only imperfect casts of the exterior and interior of this species. It appears to be very close to Panope whitfieldi Dall, from the "silex beds" of the Tampa formation of Florida.

Localities: Jacksonville, Onslow County; Trent River $31 / 2$ miles below Polloksville and Trent River 13 miles northwest of New Bern, Jones County, N. C.

Geologic horizon: Trent marl, of lower Miocene age.

\section{Class GASTROPODA \\ Order CTENOBRANCHIATA \\ Family CALYPTRAEIDAE \\ Genus CALYPTRAEA Lamarck}

Calyptraea trochiformis Lamarck

Calyptraea trochiformis Lamarck, Annales du Muséum, Paris, vol. 5, pt. 1, p. 385, pl. 15, fig. 3, 1804.

Deshayes, Descriptions des coquilles fossiles des environs de Paris, vol. 2, p. 30, pl. 4, figs. 1-4, 11-13, 1824.

Dall, Wagner Free Inst. Sci. Trans., vol. 3, pt. 2, p. 352, 1892.

Infundibulum echinulatum Sowerby (I. spinulosum, I. tuberculatum Sowerby), The mineral conchology of Great Britain, vol. 1, pl. 97, figs. 1, 2, 7, 1812 .

Infundibulum trochiformis Lea, Contributions to geology, p. 96, pl. 3, fig. 76, 1833.

Infundibulum urticosum Conrad, Fossil shells of the Tertiary formations, No. 3, p. 32, 1833.

Infundibulum perarmatum Conrad, Acad. Nat. Sci. Philadelphia Proc., pl. 1, p. 31, 1841; Fossils of the medial Tertiary of the United States, p. 80 , pl. 45 , fig. 6 , No. $3,1845$.

Trochita alta Conrad, in Wailes, Report on the agriculture and geology of Mississippi, p. 289, pl. 15, figs. 3a, 3b, 1854; Acad. Nat. Sci. Philadelphia Proc. for 1855, p. 259.

Trochita tetrica Conrad, Acad. Nat. Sci. Philadelphia Jour., ser. 2d, wol. 1, pp. 113, 133, pl. 11, fig. 3, 1848; Checklist of the invertebrate fossils of North America, Eocene, p. 28, No. $817,1866$.

Lamarck's original description is quoted below:

C'est une coquille orbiculaire, très fragile, plus ou moins hérissée d'écailles en épines. Elle a l'aspect d'un trochus; et cependant elle tient. par ses rapports aux autres calyptrées d'une manière remarquable. On en trouve plusieurs variétés qu'il seroit possible de distinguer, mais qui se nuancent entre elle dans les différens individus.

The writer has a single perfect specimen of this species in the collection from Silverdale, Onslow County, N. C. Internal casts of Calyptraea, probably C. trochiformis, are very abundant in the impure limestone of the typical Trent marl. The specimen from Silverdale is of medium size, inflated, low, with prominent spines over most of the surface. C. trochiformis Lamarck is extremely variable in form and has a great geologic and geographic range. It is therefore of little value in determining the age of the Trent formation.

Locality: Silverdale, Onslow County, N. C.

Geologic horizon: Trent marl, of lower Miocene age 


\section{Family NATICIDAE}

\section{Genus SINUM Bolten}

Sinum imperforatum Dall

Sinum imperforatum Dall, U. S. Nat. Mus., Bull. 90, p. 109 pl. 5, fig. 8, 1915 .

Dall describes this species as follows:

Shell small, elevated, solid, of about five whorls, of which the nuclear two and one-half appear smooth; subsequent whorls sharply densely grooved, the grooves having a tendency to pair, and the interspaces flattened; both grooves and interspaces are minutely zigzagged by the intersection with them of the incremental lines; spire moderately elevated, suture distinct; aperture oblique, the outer lip joining the body above the periphery of the preceding whorls; inner or pillar lip thickened, with a slight depression behind it, but no umbilical chink. Height of shell, 13.2; of aperture, 11.7; maximum diameter, 11 millimeters.

Tampa silex beds, from the vicinity of Hillsboro River, Fla.

Locality: Silverdale, Onslow County, N. C.

Geologic horizon: Trent marl, of lower Miocene age.

\section{Family TURRITELIIDAE}

Genus TURRITELLA Lamarck

Turritella fuerta Kellum, n. sp.

Plate X, Figures 8-9

Shell large, robust, acute, with age showing a tendency to loose coiling of the whorls, which are then slightly constricted in the middle; number of whorls in the figured specimen ten, the nucleus and basal whorls lost; early whorls with three rounded, spiral keels, the highest one-third the axial width of the whorl below the upper suture, the middle two-thirds below the upper suture, and the lowest keel at the base of the whorl adjoining the lower suture. In the later whorls all the keels become very indistinct, or in some specimens the basal keel remains strong and the two higher ones become obsolete. The entire surface is covered with fine, sharp, spiral threads, crossed by irregular, wavy, axial growth lines. Dimensions of figured type: Height, 67 millimeters; diameter at base, 22 millimeters.

Turritella fuerta is closely related to $T$. indenta Conrad, from the Calvert formation at Plum Point, Md. That species, hrowever, does not show the three distinct keels on the younger whorls, and the axial width of the whorls is less than in the Silverdale form.

The typical form of $T$. fuerta is very similar to $T$. (tampae var.?) medioconstrica Dall, from the "silex beds" of the Tampa formation of Florida. It is a much larger and heavier shell than Dall's species, and the axial width of the whorls is greater. The early whorls of T. medioconstricta have only two spiral keels instead of three, as in T. fuerta.

Individuals of $T$. fuerta that retain the strong keel at the bottom of the later whorls strikingly resemble
T. megalobasis Dall, from the "silex beds" of the Tampa of Florida, which, however, has a somewhat larger apical angle and is a thinner shell. The finer details of sculpture are not preserved on the specimens of this variety from Silverdale.

Locality: Silverdale, Onslow County, N. C.

Geologic horizon: Trent marl, of lower Miocene age.

Family BUCCINIDAE

Genus BUSYCON Bolton

Busycon spiniger var. onslowensis Kellum, n. var.

Plate XI, Figures 1-3

Shell usually small, subcarinate, with elevated spire of about four and one-half whorls; nucleus small and smooth; the very small whorls immediately following the nucleus minutely undulate along the shoulder, which is scarcely raised above the suture; later whorls with distinct, rather widely spaced spines along the rounded shoulder, which becomes increasingly elevated above the suture toward the aperture; surface of shell covered with faint, parallel spiral lines; interior of shell smooth. The anterior canal is broken and the surface is much worn on all the specimens in the collection. Large fragments obtained show the species to attain a height of 5 inches or more in the adult form. Dimensions of type: Height (anterior canal broken), 41 millimeters; maximum diameter, 35 millimeters.

The variety onslowensis is closest to Busycon spiniger var. spiniger (Conrad) from the Vicksburgian Red Bluff clay of Mississippi. In the Vicksburg variety the spines along the shoulder are more produced in the later whorls and entirely absent in the earlier ones; the earlier whorls have an angulated keel, which is distinctly elevated above the suture; the later whorls are not appressed near the suture; and the fine spiral sculpture is usually more prominent.

Locality: Silverdale, Onslow County, N. C.

Geologic horizon: Trent marl, of lower Miocene age.

\section{Family VOLUTIDAE \\ Genus LYRIA Gray}

Lyria carolinensis Kellum, n. sp.

Plate XI, Figures 4-5

Shell fusiform, with an elevated spire of about five volutions; nucleus small, smooth; whorls axially sculptured with closely spaced, low costae numbering about 28 on the body whorl; base of body whorl spirally sculptured with a few impressed striae; outer lip thickened on the border, slightly ascending; inner lip irregularly plicated over its entire extent, the two or three basal plicae much the strongest; aperture somewhat more than two-thirds the height of the shell, moderately wide, elliptical, and broadly canaliculate 
anteriorly. Height, 31 millimeters; maximum diameter, 15 millimeters.

This species is closely related to Lyria heilprini Dall, from the "silex beds" of the Tampa formation of Florida. It is distinguished from that form by its thinner shell, much smaller nucleus, relatively higher and broader aperture, with the outer margin much less thickened, and fewer axial costae on the body whorl. The costae are more closely spaced and are less sharply defined.

Locality: Silverdale, Onslow County, N. C.

Geologic horizon: Trent marl, of lower Miocene age.

Genus SCAPHELLA Swainson

Scaphella stromboidella Kellum, n. sp.

Plate XI, Figures 6-7

Shell large, thick, stoutly fusiform, of four or five whorls; nucleus small for the genus, with a distinct spur or elevated point, and composed of about one and one-half whorls; suture closely appressed, the whorl somewhat constricted in front of it; aperture somewhat more than two-thirds the height of the shell, moderately broad, with a straight anterior canal which is not constricted off; outer lip broken; inner lip with three coarse, inclined plaits and a fourth smaller one anterior. The exterior of all specimens in the collection is very much worn. A single young shell shows a spiral sculpture of fine threads near the top of the whorls. Axial growth lines distinct. Height, 71 millimeters; maximum diameter, 34 millimeters.

Scaphella stromboidella is very close to an undescribed species from the Shoal River formation on Whites Creek, Walton County, Fla. The superficial appearance of the two forms is almost identical. The Shoal River species, however, is smaller than the adult $S$. stromboidella and has strong axial ribbing on the early whorls of the shell.

Locality: Silverdale, Onslow County, N. C.

Geologic horizon: Trent marl, of lower Miocene age.
Family OLIVIDAE

Genus OIIVA Martyn

Oliva posti Dall

Oliva posti Dall, U. S. Nat. Mus. Bull. 90, p. 49, pl. 12, fig. 24, 1915.

Shell small, solid, smooth, with four or more whorls; nucleus defective; suture moderately channeled; shell rather slender; last whorl with a wash of callus near the suture; aperture long and narrow, acute behind; outer lip slightly thickened, internally smooth; inner lip plicate in front as figured; canal deeply excavated. Height, 21.5 millimeters; height of last whorl, 18 millimeters; maximum diameter, 8.5 millimeters.

Locality: Silverdale, Onslow County, N. C.

Geologic horizon: Trent marl, of lower Miocene age. Found in the "Tampa silex beds at Ballast Point, Tampa Bay, Fla.," according to Dall.

\author{
Family CONIDAE \\ Genus CoNUS Linné \\ Conus postalveatus Kellum, n. sp. \\ Plate XI, Figures 8-10
}

Shell of moderate size, with obtuse or very slightly acute spires of about ten whorls; nucleus destroyed; whorls somewhat excavated on top, spirally sculptured with fine grooves, and bounded by an angular shoulder; early whorls faintly nodulated at the shoulder; sides of outer whorl longitudinally nearly straight, faintly sculptured with fine, spiral striae, which toward the base become distinct grooves; axial growth lines distinct; aperture narrow, elongate, the canal short and wide; outer lip broken; inner lip with a single welldefined plait at the base of the columella. Height, 38 millimeters; diameter, 19.5 millimeters.

The form closest to this species is Conus alveatus Conrad, from the Oligocene of Vicksburg, Miss., a shorter cone with a much coarser spiral sculpture near the base of the outer whorl.

Locality: Silverdale, Onslow County, N. C.

Geologic horizon: Trent marl, of lower Miocene age. 


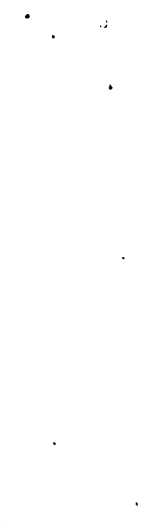




$\overline{0 .}$




\section{PLATE I}

Figures 1-3. Cassidulus (Pygorhynchus) carolinensis var. cravenensis Kellum, n. var. (p. 15). U. S. Nat. Mus. catalogue No. 353256 , type; 3 miles east of Quinerly, Pitt County, N. C.

1. Upper surface of the test.

2. Lower surface of the test.

3. Left lateral surface of the tect.

Figures 4-7. Cassidulus (Pygorhyruhus) berryi Kellum, n. sp. (p. 15). U. S. Nat. Mus. catalogue No. 353233, type; 2 miles north of Jacksonville, Onslow County, N. C.

4. Upper surface of the test.

5. Lower surface of the test.

6. Right lateral surface of the test.

7. Anterior surface of the test.

Figures 8-9. Linthia hanoverensis Kellum, 1. sp. (p. 15). U. S. Nat. Mus. catalogue No. 164664, type; Wilmington, New Hanover County, N. C.

8. Upper surface of the test.

9. Left lateral surface of the test.

Figures 10-12. Arca sp. $c$ (p. 16); Wilmington, N. C.

10. Internal cast of right valve. U. S. Nat. Mus. catalogue No. 353315.

11. Internal cast of right valve. U. S: Nat. Mus. catalogue No. 353298.

12. Sculpture on postero-dorsal surface of specimen illustrated in Figure 11, as shown by a gutta-percha squeeze.

FiguRes 13-14. Arca sp. $a$ (p. 16).

13. Internal cast of left valve from old Rocky Point, Pender County, N. C. U. S. Nat. Mus. catalogue No. 353300.

14. Internal cast of right valve from Wilmington, N. C. (?). U. S. Nat. Mus. catalogue No. 353301.

FigURE 15. $A r c a$ sp. $b$ (p, 16). Internal cast of left valve, from Wilmington, N. C. U. S. Nat. Mus. catalogue No. 353304. 


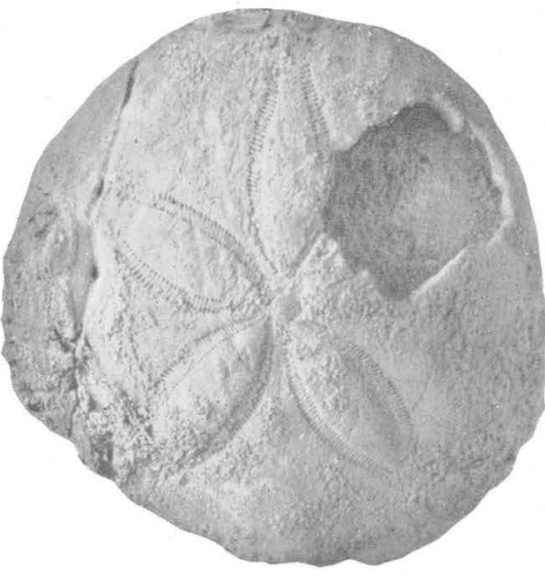

4

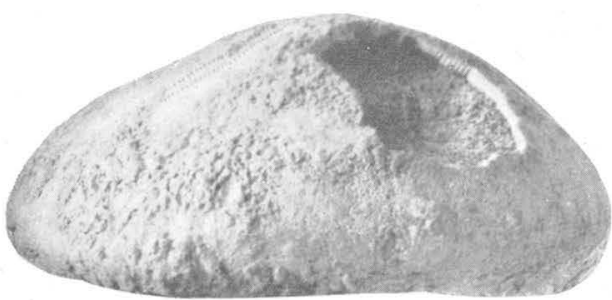

6

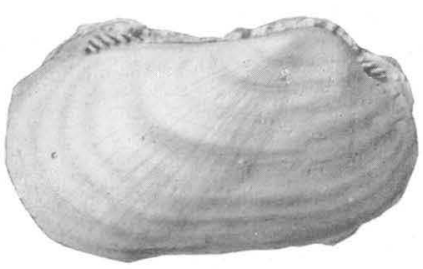

10
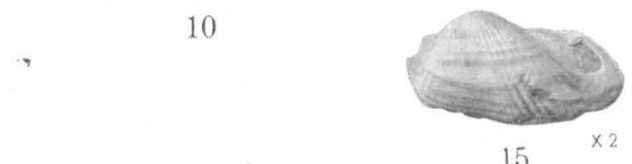

15
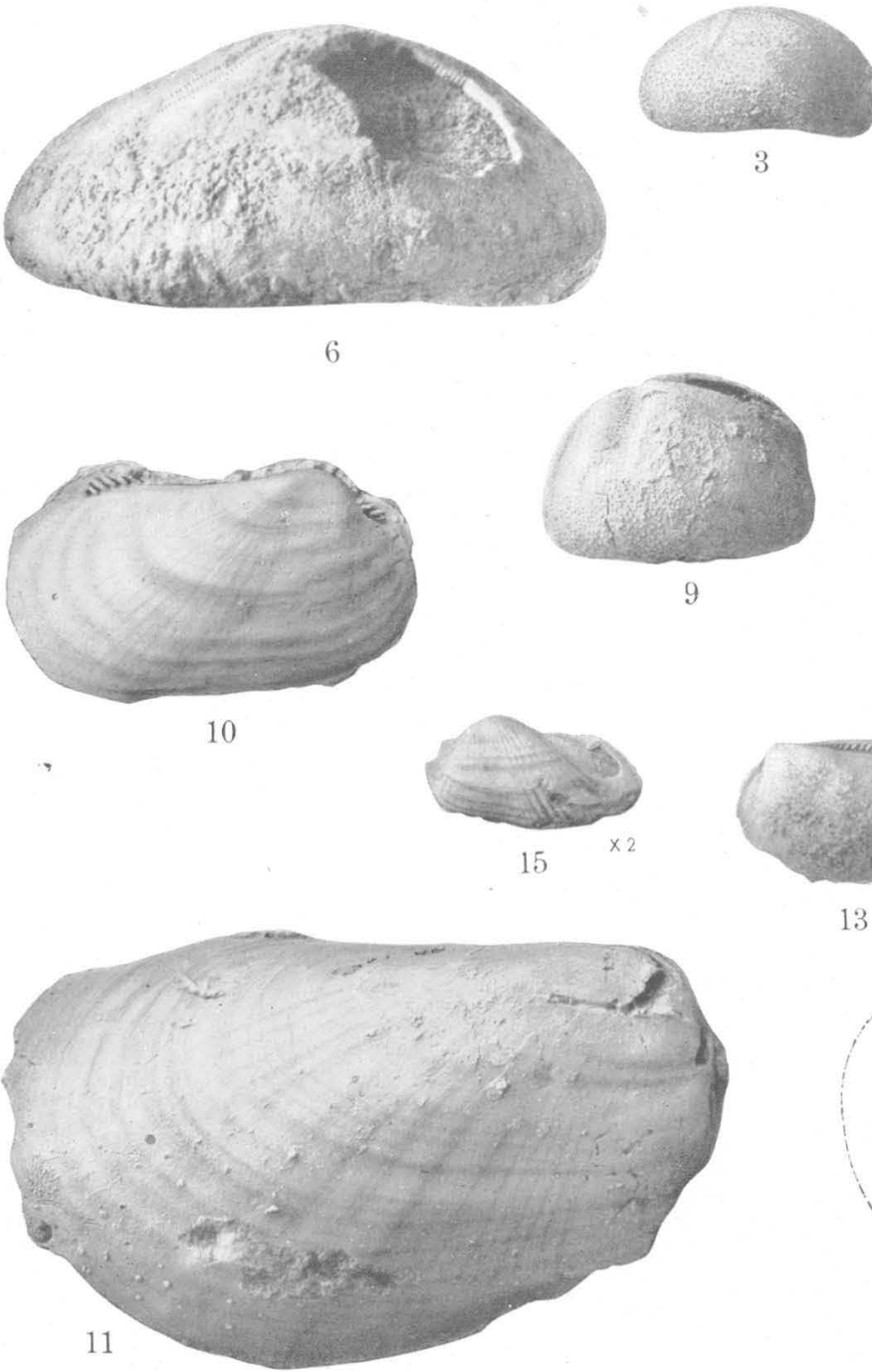

3

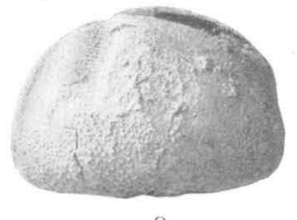

9

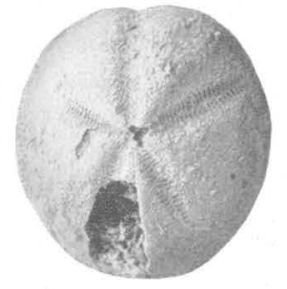

8

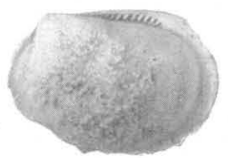

13

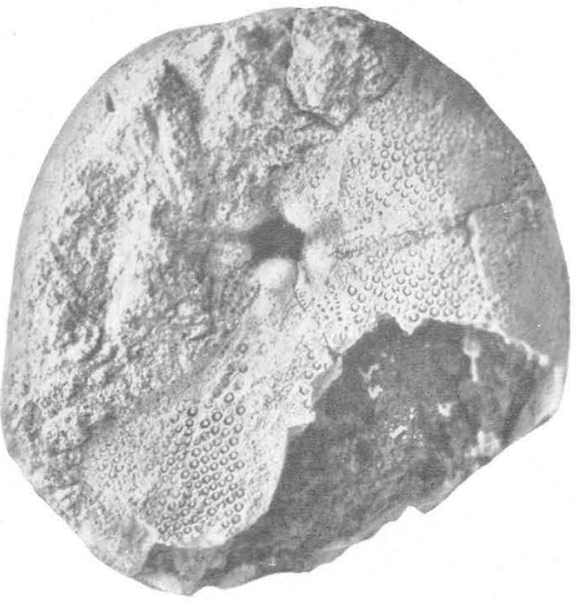

5

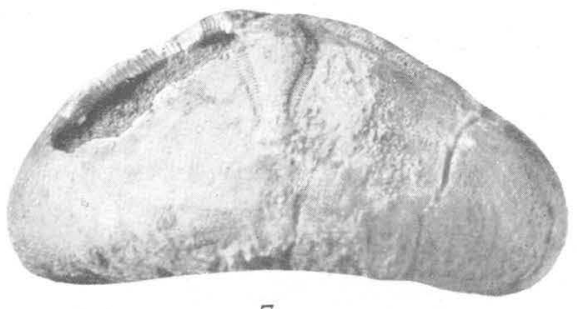

7

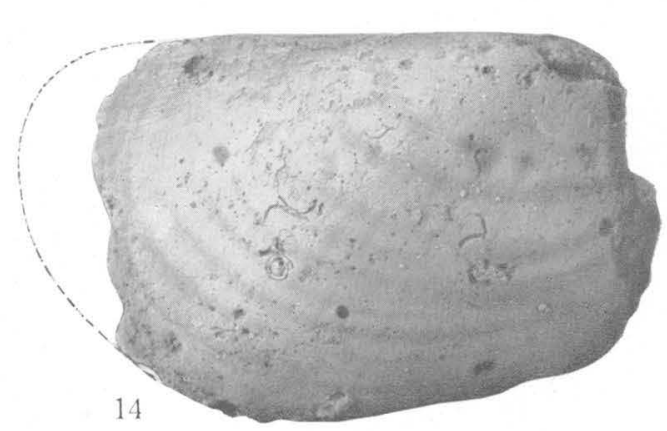

$51278-26 \dagger-4$

FOSSILS FROM THE CASTLE HAYNE MARL 
U. S. GEOLOGICAL SURVEY
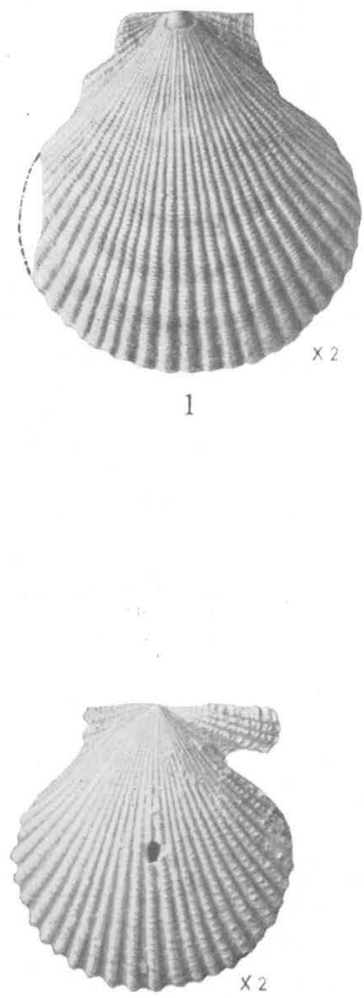

3

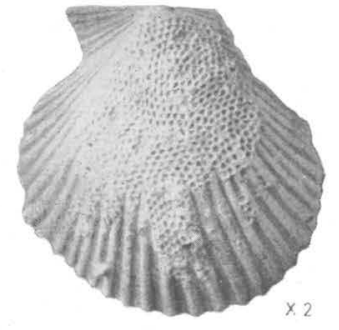

2

PROFESSIONAL PAPER 143 PLATE II
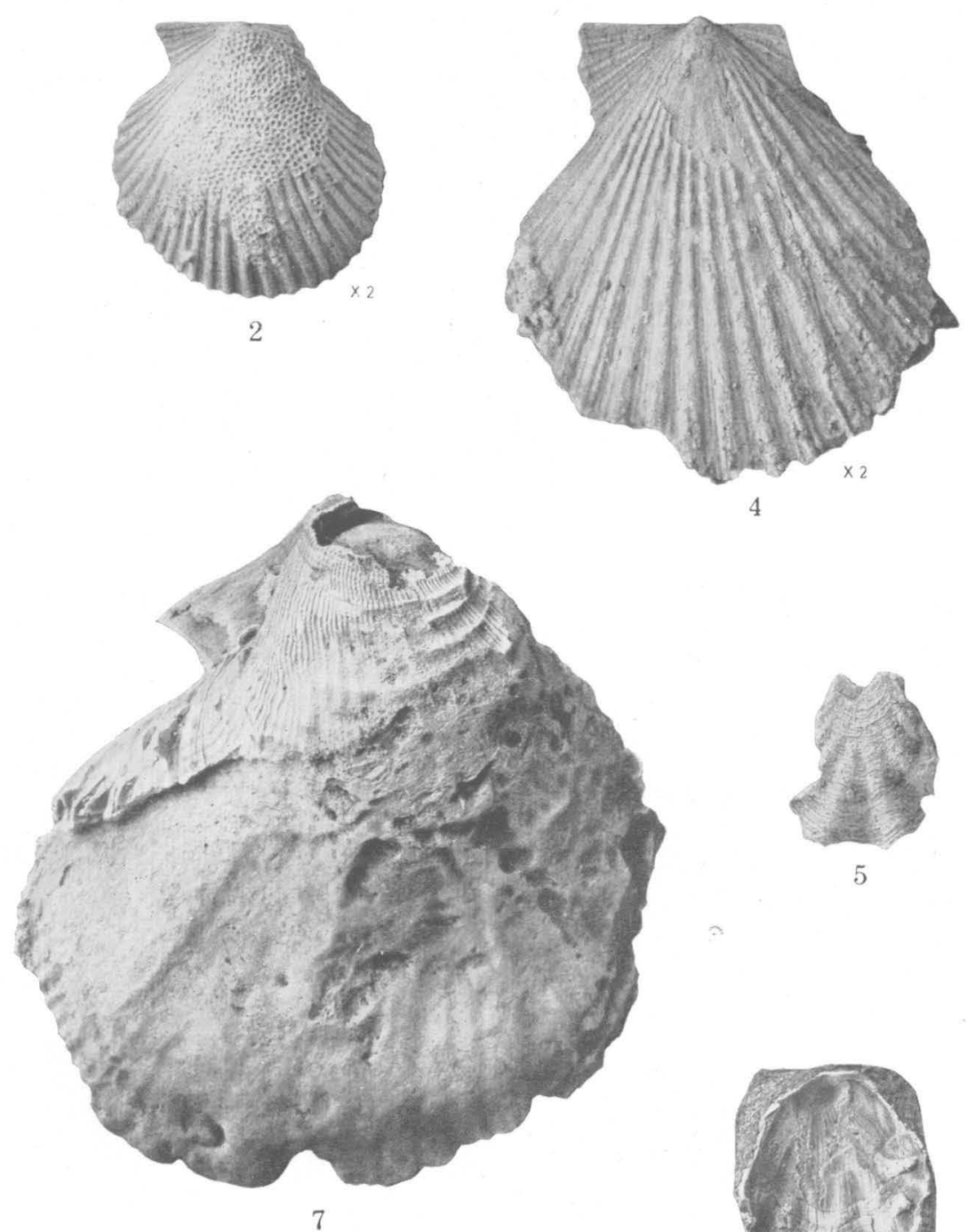

5

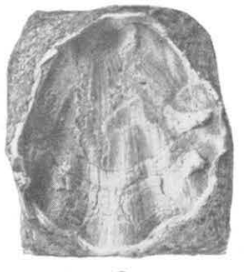

6

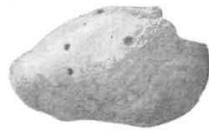

10

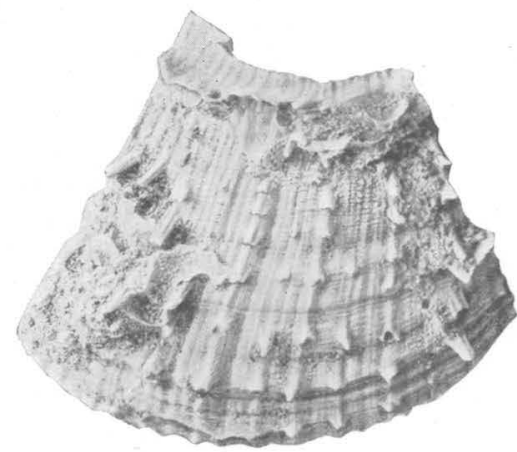

9

FOSSILS FROM THE CASTLE HAYNE MARI 


\section{PLATE II}

Figure 1. Pecten cushmani Kellum, n. sp. (p. 20). The type, a left valve from a locality 3 miles east of Quinerly, Pitt County, N. C. U. S. Nat. Mus. catalogue No. 353314.

Figures 2-3. Pecien cookei Kellum, n. sp. (p. 20).

2. A left valve from a locality 3 miles south of Magnolia, Duplin County, N.C. U. S. Nat. Mus. catalogue No. 353234.

3. The type, a right valve from the same locality. U. S. Nat. Mus. catalogue No. 353235 .

Frgure 4. Pecten biddleana Kellum, n. sp. (p.. 20). The type, a left valve from Biddle Landing, Neuse River, Craven County, N. C. U. S. Nat. Mus. catalogue No. 353236.

Figures 5-6. Plicatula filamentosa Conrad (p. 21).

5. A specimen from a locality 10 miles northwest of Jacksonville, Onslow County, N. C. U. S. Nat. Mus. catalogue No. 353290 .

6. Interior of a specimen from the same locality. U. S. Nat. Mus. catalogue No. 353237.

Figures 7-9. Spondylus lamellacea Kellum, n. sp. (p. 21).

7. An imperfect specimen from Northeast Cape Fear River $31 / 2$ miles above Castle Hayne Bridge. U. S. Nat. Mus. catalogue No. 353297.

S. The type, from the same locality. U. S. Nat. Mus. catalogue No. 353282.

9. A fragment showing sculpture from the same locality. U. S. Nat. Mus. catalogue No. 353281.

Fraure 10. Anomia sp. (p. 21). A specimen from a locality 3 miles east of Quinerly, Pitt County, N. C. U. S. Nat. Mus. catalogue No. 353251 . 


\section{PLATE III}

Figure 1. Crassatellites sp. $a$ (p. 22). Internal cast of a right valve from Wilmington, N. C. U. S. Nat. Mus. catalogue No. 353292.

Figure 2. Crassatellites sp. $b$ (p. 23). Internal cast of a left valve from old Rocky Point, Pender County, N. C. U. S. Nat. Mus. catalogue No. 353293.

Fradre 3. Venericardia nasuta Dall ? (p. 23). Internal cast of a left valve from Wilmington, N. C. U. S. Nat. Mus. catalogue No. 353247.

Figdre 4. Venericardia sp. (p. 23). Internal cast of a left valve from Wilmington, N. C. U. S. Nat. Mus. catalogue No. 353250.

Figure 5. Chama sp. $a$ (p. 23). Internal cast of a left valve from Wilmington, N. C. U. S. Nat. Mus. catalogue No. 353260.

Figure 6. Chama sp. $b$ (p. 23). Internal view of a left valve from Wilmington, N. C. U. S. Nat. Mus. catalogue No. 353248.

Figure 7. Lucina sp. (p. 23). Internal cast showing left side, from Wilmington, N. C. U. S. Nat. Mus. catalogue No. 353259.

Frgure 8. Gastrochaena sp. (p. 24). Internal cast showing right side, from Wilmington, N. C. U. S. Nat. Mus. catalogue No. 353258.

Figdre 9. Fissuridea penderensis Kellum, n. sp. (p. 25). Squeeze of the type, showing the sculpture of the outer surface, from old Rocky Point, Pender County, N. C. U. S. Nat. Mus. catalogue No. 138112.

FIgure 10. Fissuridea sp. (p. 25). Internal cast of a specimen from Wilmington, N. C. U. S. Nat. Mus. catalogue No. 353280. 46 
U. S. GEOLOGICAL SURVEY
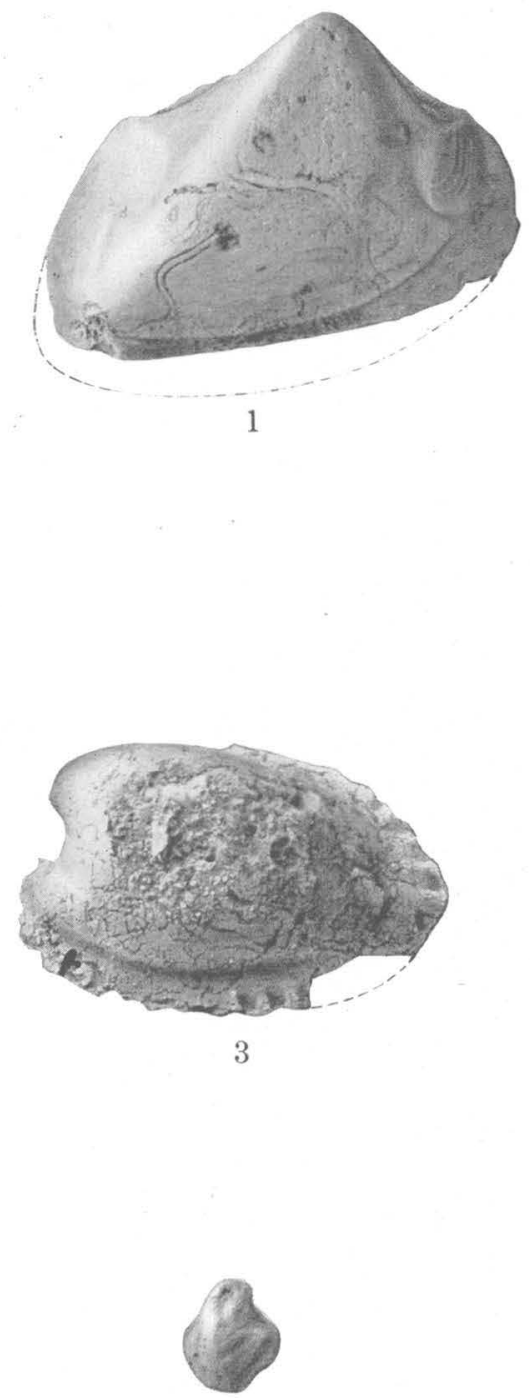

6

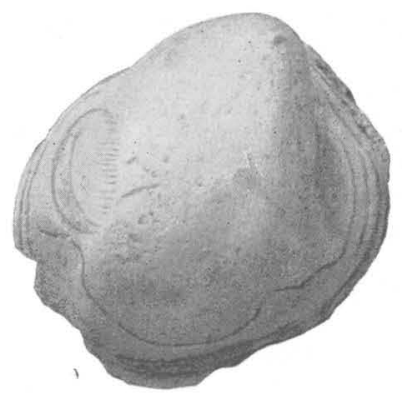

5
PROFESSIONAL PAPER 143 PLATE III
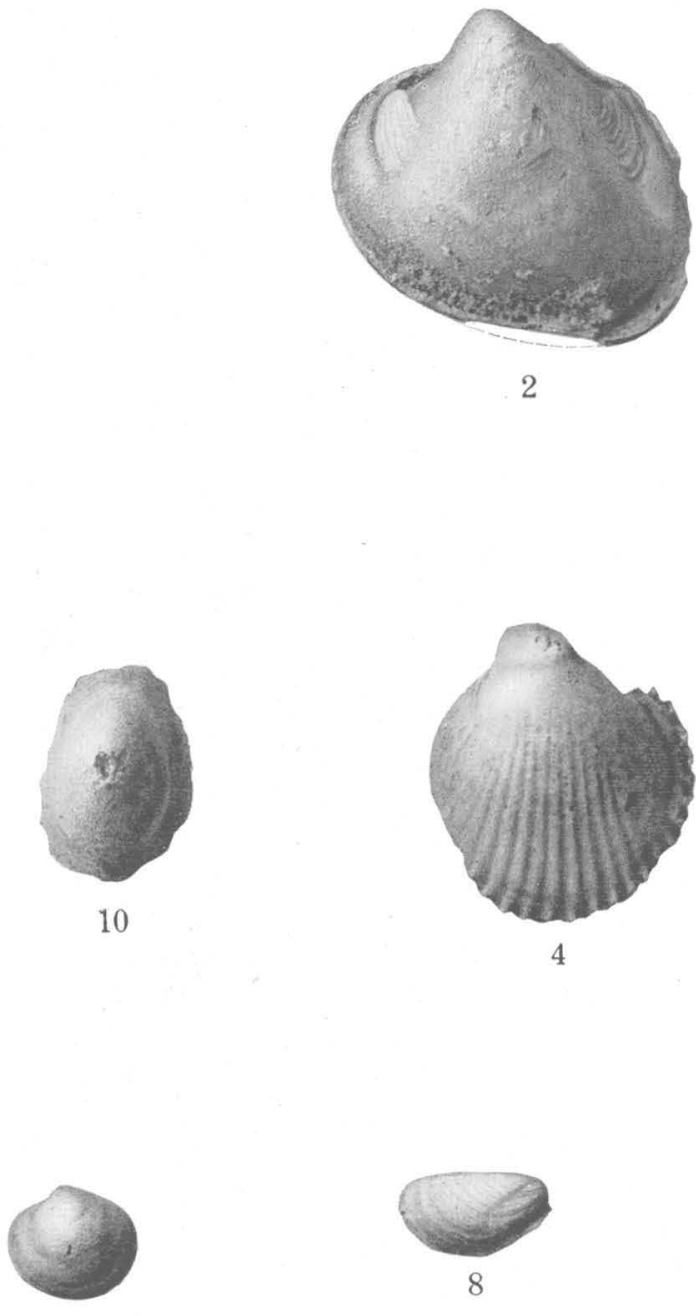

8

7

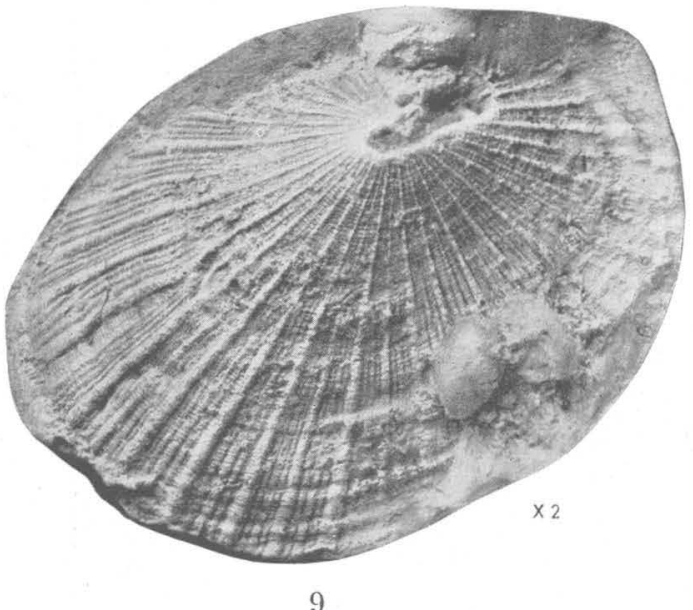

9

FOSSILS FROM THE CASTLE HAYNE MARI 

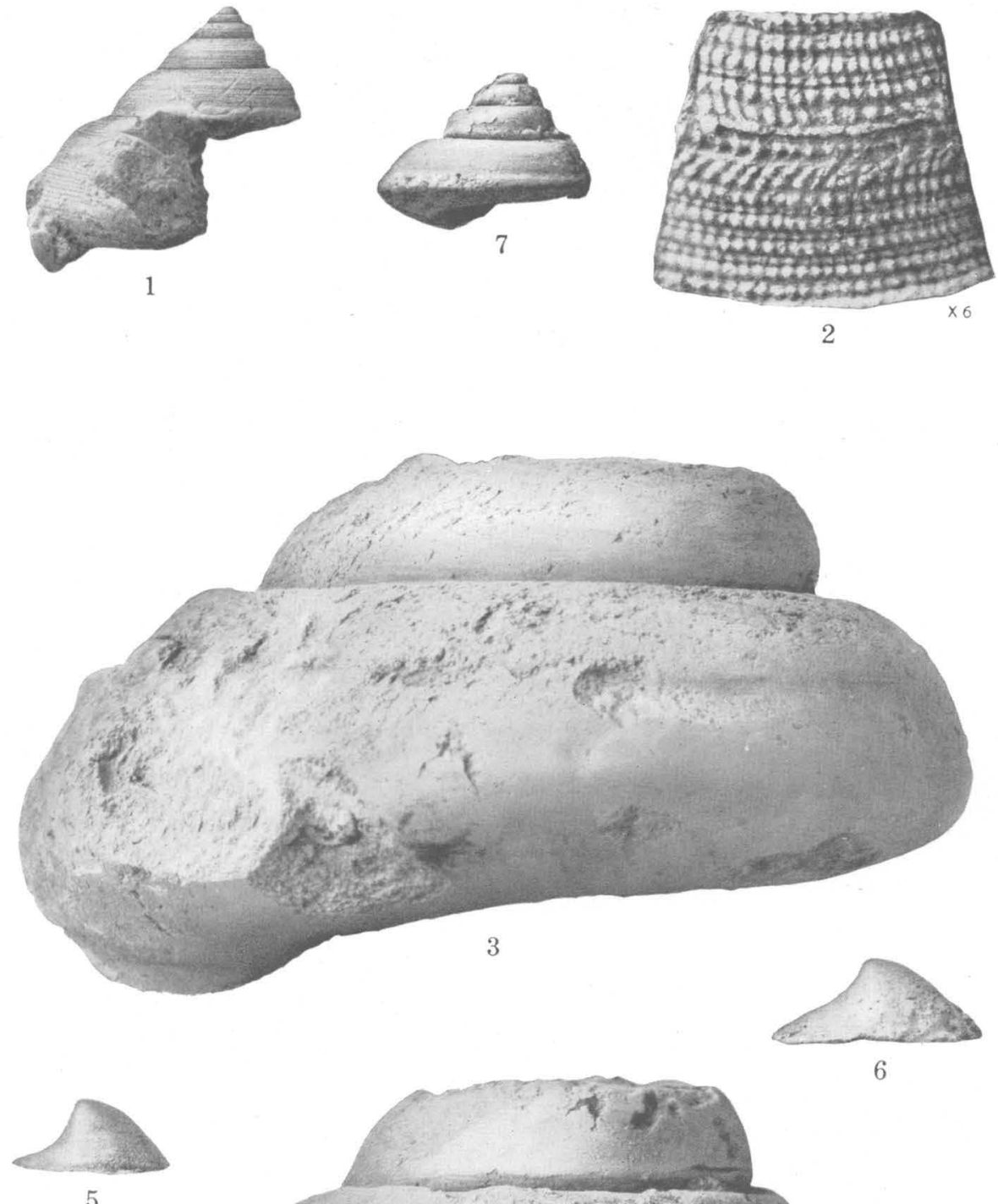

5

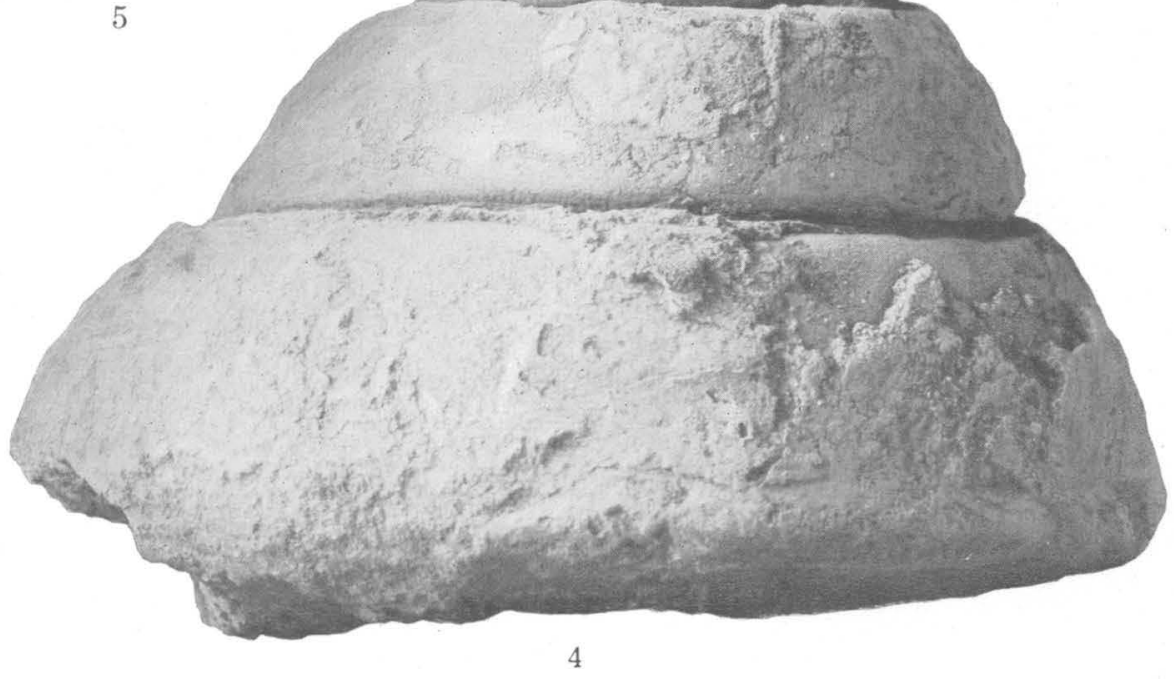

FOSSILS FROM THE CASTLE HAYNE MARL 


\section{PLATE IV}

Frgoras 1-2. Pleurotomaria hanoverensis Kellum, n. sp. (p. 24). The type from Wilmington, N. C. U. S. Nat. Mus. catalogue No. 353226.

1. Squeeze showing the sculpture and form.

2. Portion of the surface.

Fraura 3. Pleurolomaria sp. $a$ (p. 25). Internal cast of a specimen from Wilmington, N. C. U. S. Nat. Mus. catalogue No. 353288.

Fraure 4. Pleurotomaria sp. $b$ (p. 25). Internal cast of a specimen from Wilmington, N. C. U. S. Nat. Mus. catalogue No. 353289.

Figure 5. Emarginula sp. $a$ (p. 26). Internal cast of a specimen from Wilmington, N. C. U. S. Nat. Mus. catalogue No. 353241.

Figore 6. Emarginula sp. $b$ (p. 26). Internal cast of a specimen from old Rocky. Point, Pender County, N. C. U. S. Nat. Mus. catalogue No. 138074.

Figurs 7. Calliostoma sp. (p. 26). Internal cast of a specimen from old Rocky Point, Pender County, N. C. U. S. Nat. Mus. catalogue No. 353275 . 


\section{PLATE V}

Figure 1. Epitonium aequabile Kellum, n. sp. (p. 26). The type, from Wilmington, N. C. U. S. Nat. Mus. catalogue No. 353238. FrgURe 2. Epitonium dignitatis Kellum, n. sp. (p. 26). Gutta-percha squeeze of the type, a mold showing the sculpture and form from Wilmington, N. C. U. S. Nat. Mus. catalogue No. 353243.

Figure 3. Calyptraea sp. (p. 27). Internal cast of a specimen from Wilmington, N. C. U. S. Nat. Mus. catalogue No. 353278.

Figure 4. Xenophora sp. (p. 27). Internal cast of a specimen from old Rocky Point, Pender County, N. C. U. S. Nat. Mus. catalogue No. 353231.

Figure 5. Turritella subtilis Kellum n. sp. (p. 27). Squeeze showing sculpture and form of the type, from Wilmington, N. C. U. S. Nat. Mus. catalogue No. 353240 .

Figure 6. Turritella sp. (p. 27). Internal cast of a specimen from old Rocky Point, Pender County, N. C. U. S. Nat. Mus. catalogue No. 353232.

Figure 7. Strombus sp.? (p. 27). Internal cast of a specimen from Wilmington, N. C. U.S. Nat. Mus. catalogue No. 353279.

Figure 8. Cypraea sp. $a$ (p. 28). Internal cast of a specimen from Wilmington, N. C. U. S. Nat. Mus. catalogue No. 353268.

FrgURE 9. Cypraea sp. $b$ (p. 28). Internal cast of a specimen from Wilmington, N. C. U. S. Nat. Mus. catalogue No. 353267.

Frgure 10. Cypraea sp. $c$ (p. 28). Internal cast of a specimen from Wilmington, N. C. U. S. Nat. Mus. catalogue No. 353266.

Figures 11-12. Cypraea sp. $d$ (p. 28). Specimen from old Rocky Point, Pender County, N. C. U. S. Nat. Mus. catalogue No. 353265 .

11. Internal cast.

12. Top view.

FiguRe 13. Cypraea sp. $e$ (p. 28). Internal cast of a specimen from old Rocky Point, Pender County, N. C. U.S. Nat. Mus. catalogue No. 353264.

Figưres 14-15. Cassis? sp. (p: 28).

14. Internal cast of a specimen from Wilmington, N. C. U. S. Nat. Mus. catalogue No. 353257.

15. Internal cast of another specimen from the same locality. U. S. Nat. Mus. catalogue No. 353228.

Figure 16. Phalium sp. (p. 29). Internal cast of a specimen from old Rocky Point, Pender County, N. C. U. S. Nat. Mus. catalogue No. 353316.

Figure 17. Ptychosalpinx sp. (p. 29). Internal cast of a specimen from old Rocky Point, Pender County, N. C. U. S. Nat. Mus. catalogue No. 138090.

Frgure 18. Marginella sp. (p. 30). Internal cast of a specimen from old Rocky Point, Pender County, N. C. U. S. Nat. Mus. catalogue No. 353274 .

FrgURe 19. Mitra sp. $a$ (p. 30). Internal cast of a specimen from Wilmington, N. C. U. S. Nat. Mus. catalogue No. 353287.

Figure 20. Mitra sp. $b$ (p. 30). Internal cast of a specimen from old Rocky Point, Pender County, N. C. U.S. Nat. Mus. catalogue No. 353286.

Frgure 21. Mitra sp. $c$ (p. 30). Internal cast of a specimen from old Rocky Point, Pender County, N. C. U. S. Nat. Mus. catalogue No. 353317.

Figure 22. Mitra sp. $d$ (p. 30). Internal cast of a specimen from old Rocky Point, Pender County, N. C. U.S. Nat. Mus. catalogue No. 353284 .

Figure 23. Mitra sp. $e$ (p. 30). Internal cast of a specimen from old Rocky Point, Pender County, N. C. U. S. Nat. Mus. catalogue No. 353283.

Figure 24. Mitra sp. $f$ (p. 30). Internal cast of a specimen from old Rocky Point, Pender County, N. C. U. S. Nat. Mus. catalogue No. 138079. 
U. S. GEOLOGICAL SURVEY
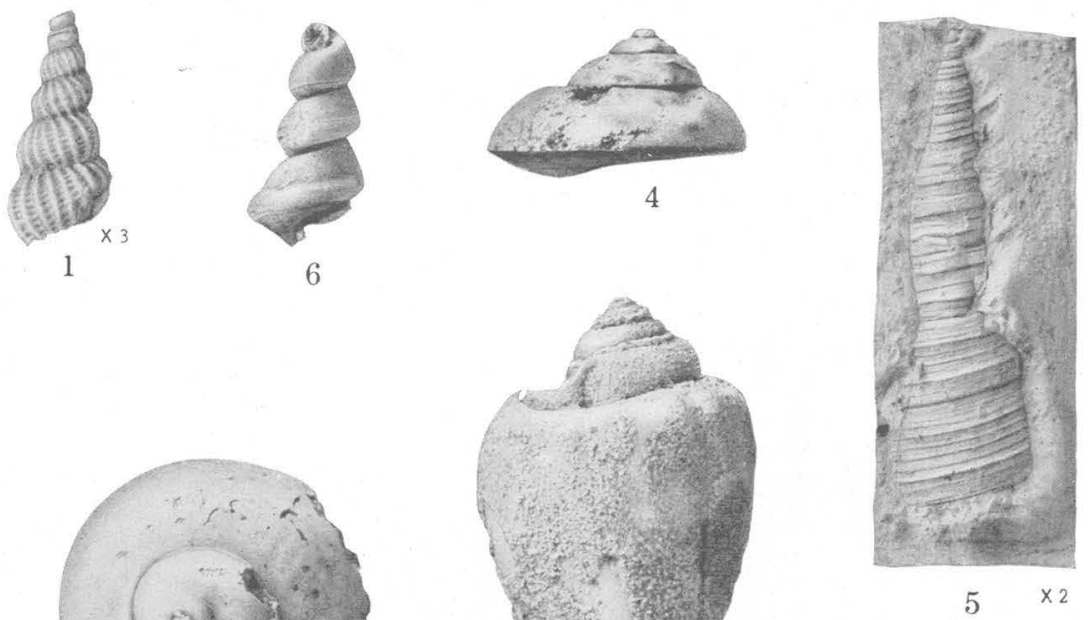

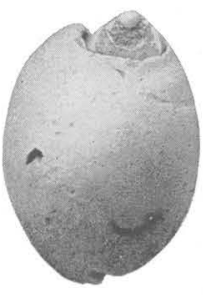

8

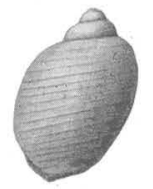

14
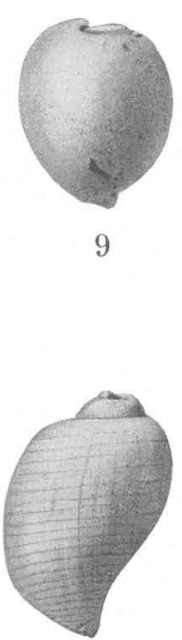

15
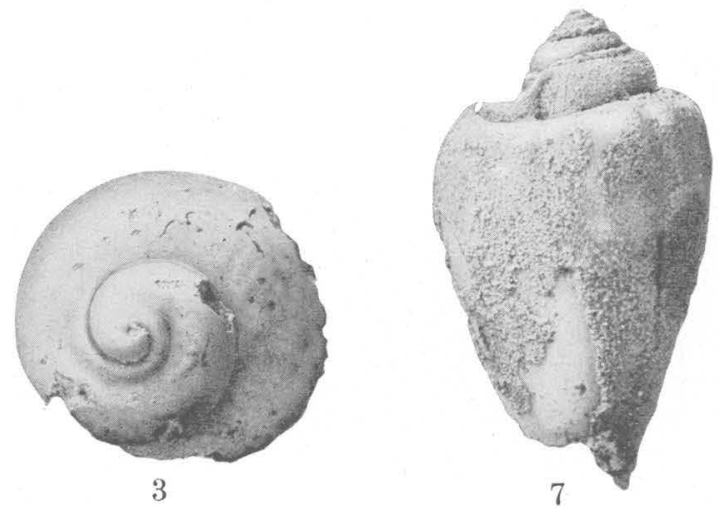

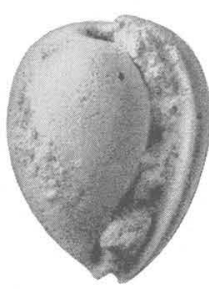

10

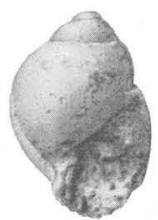

16

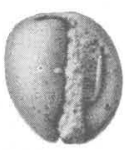

11

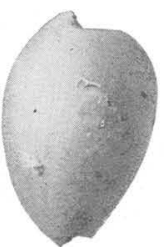

13

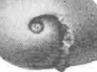

12

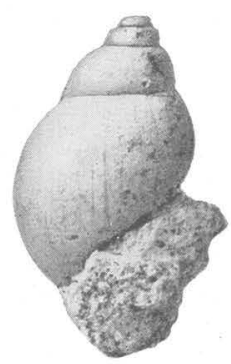

17

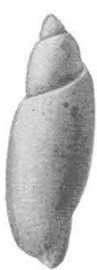

19

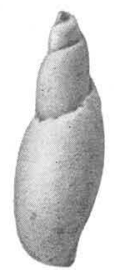

20

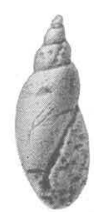

21

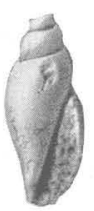

22

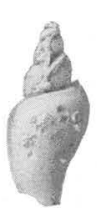

23

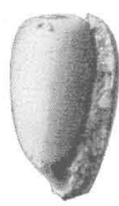

18

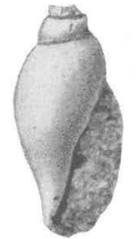

24

FOSSULS FROM THE CASTLE HAYNE MARL 
J. S. GEOLOGICAL SURVEY

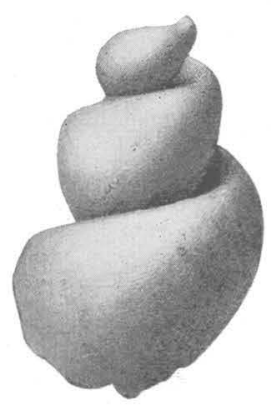

2

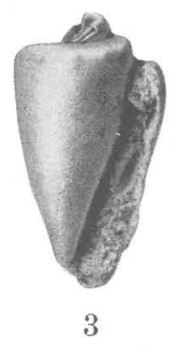

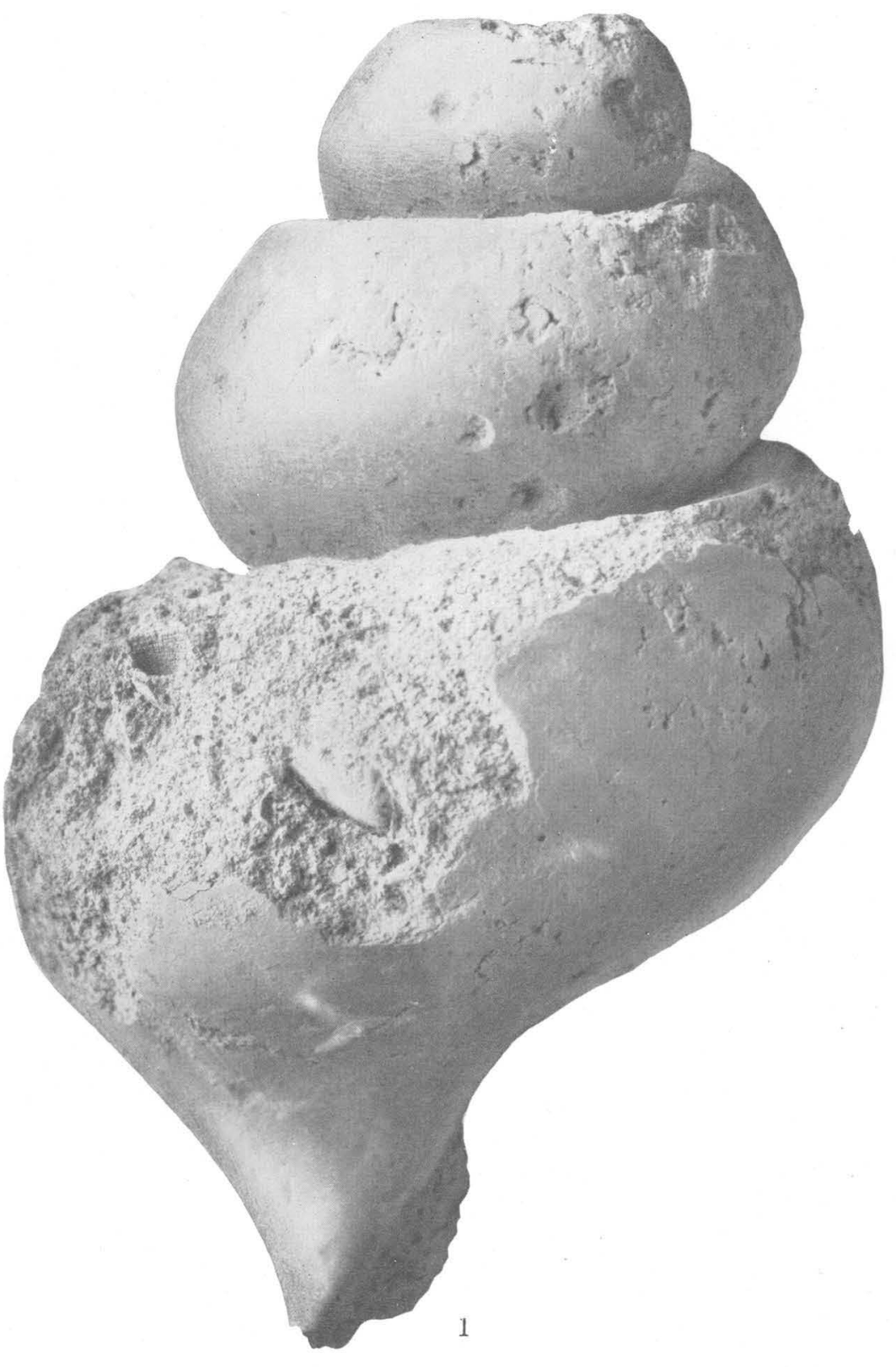

FOSSILS FROM THE CASTLE HAYNE MARL 


\section{PLATE VI}

Figure 1. Fusinus abruptus (Tuomey)? (p. 29). Internal cast of a specimen from Wilmington, N. C. U. S. Nat. Mus. catalogue No. 353312.

Fraure 2. Fusinus sp. (p. 29). Internal cast of a specimen from Wilmington, N. C. U. S. Nat. Mus. catalogue No. 353285.

Figone 3. Plejona cf. P. petrosus (Conrad) (p. 31). Internal cast of a specimen from Wilmington, N. C. U. S. Nat. Mus. catalogue No. 353277.

Figure 4. Plejona conoides (Tuomey)? (p. 31). Internal cast of a specimen from Wilmington, N. C. U. S. Nat. Mus. catalogue. No. 353276 . 


\section{PLATE VII .}

Figure 1. Caricella? sp. (p. 31). Internal cast of a specimen from Wilmington, N. C. U. S. Nat. Mus. catalogue No. 353245. Figures 2-3. Conus mutilatus Tuomey? (p. 31).

2. Internal cast of a specimen from Wilmington, N. C. U. S. Nat. Mus. catalogue No. 353271 .

3. Internal cast of another specimen from the same locality. U. S. Nat. Mus. catalogue No. 353272 .

Figure 4. Conus? sp. (p. 32). Internal cast of a specimen from old Rocky Point, Pender County, N. C. U. S. Nat. Mus. catalogue No. 353269.

Figures 5-7. Eutrephoceras carolinensis Kellum, n. sp. (p. 32).

5. Side view of the type, a cast, from Wilmington, N. C. U. S. Nat. Mus. catalogue No. 353299 .

6. Front or apertural view of the same specimen.

7. Cast of one of the chambers showing the position of the siphuncle, from Wilmington, N. C. U. S. Nat. Mus. catalogue No. 138051.

Figures 8-13. Terebratula crassa Kellum, n. sp. (p. 34).

8. Side view of the ventral valve of the type, from a locality 5 miles west of Pink Hill, Duplin County, N. C. U. S. Nat. Mus. catalogue No. 353263.

9. Exterior of the type.

10. Interior of the type with a fragment of the dorsal valve attached.

11. Exterior of a dorsal valve from the same locality. U. S. Nat. Mus. catalogue No. 353262 .

12. Interior of the specimen shown in Figure 11.

13. Interior of a ventral valve from the same locality. U. S. Nat. Mus. catalogue No. 353261 .

50 
U. S. GEOLOGICAL SURVEY
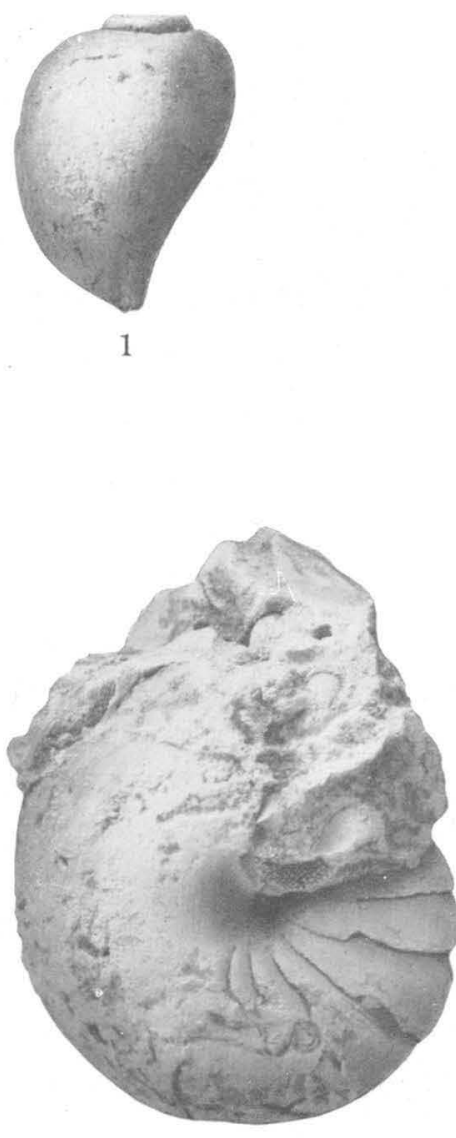

5
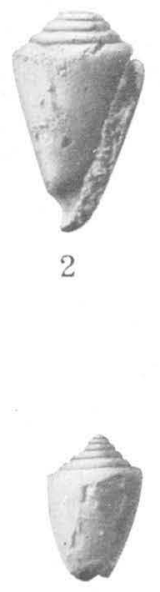

4
PROFESSIONAL PAPER 143 PLATE VII

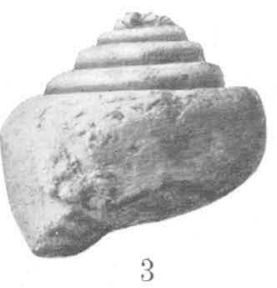

3

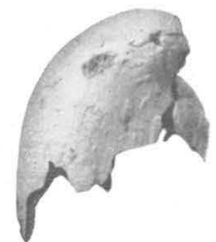

8

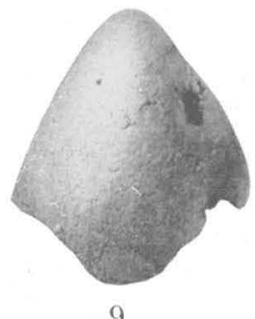

9

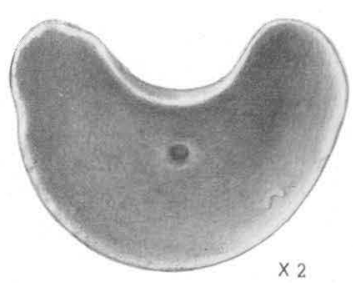

7

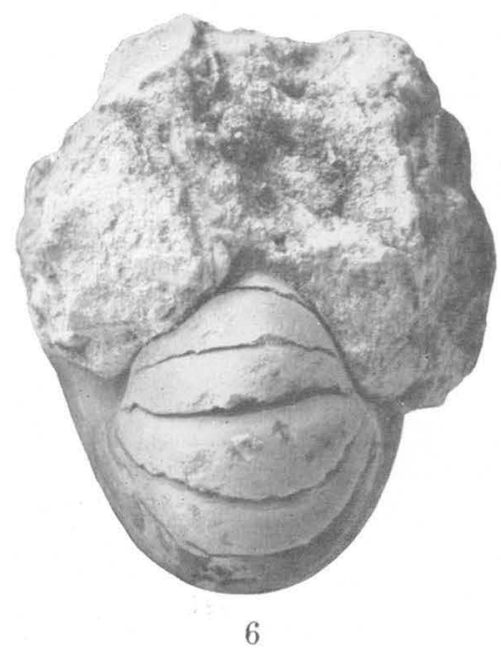

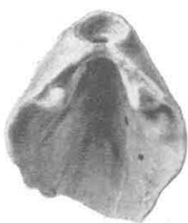

13

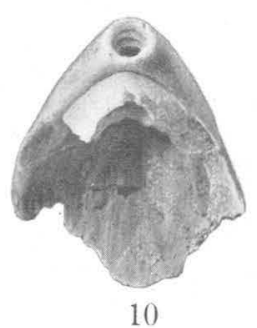

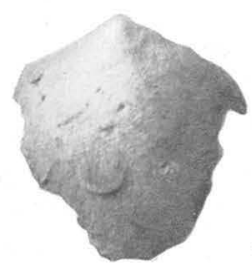

11

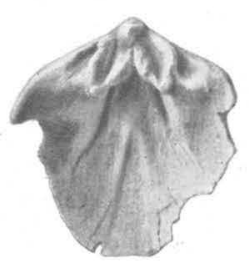

12

FOSSILS FROM THE CASTLE HAYNE MARL 
ర. S. GEOLOGICAL SURVEY
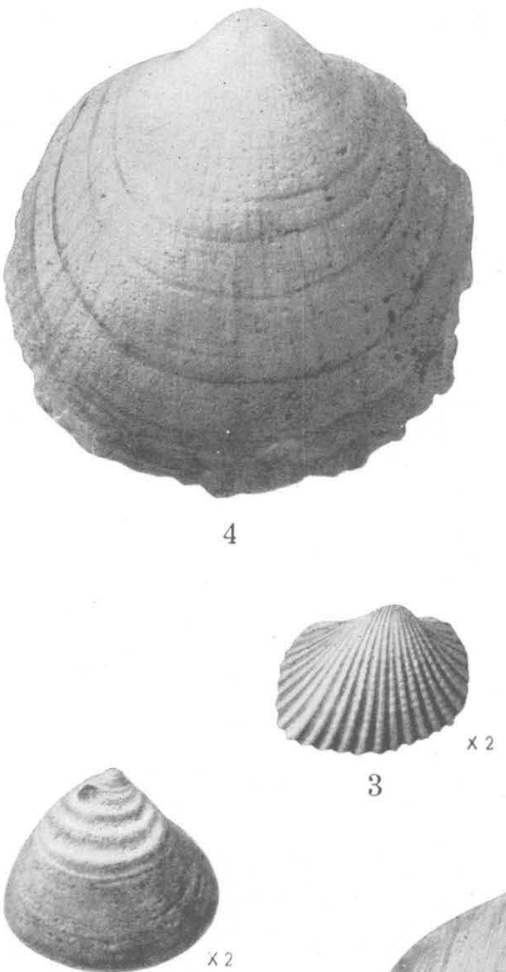

8
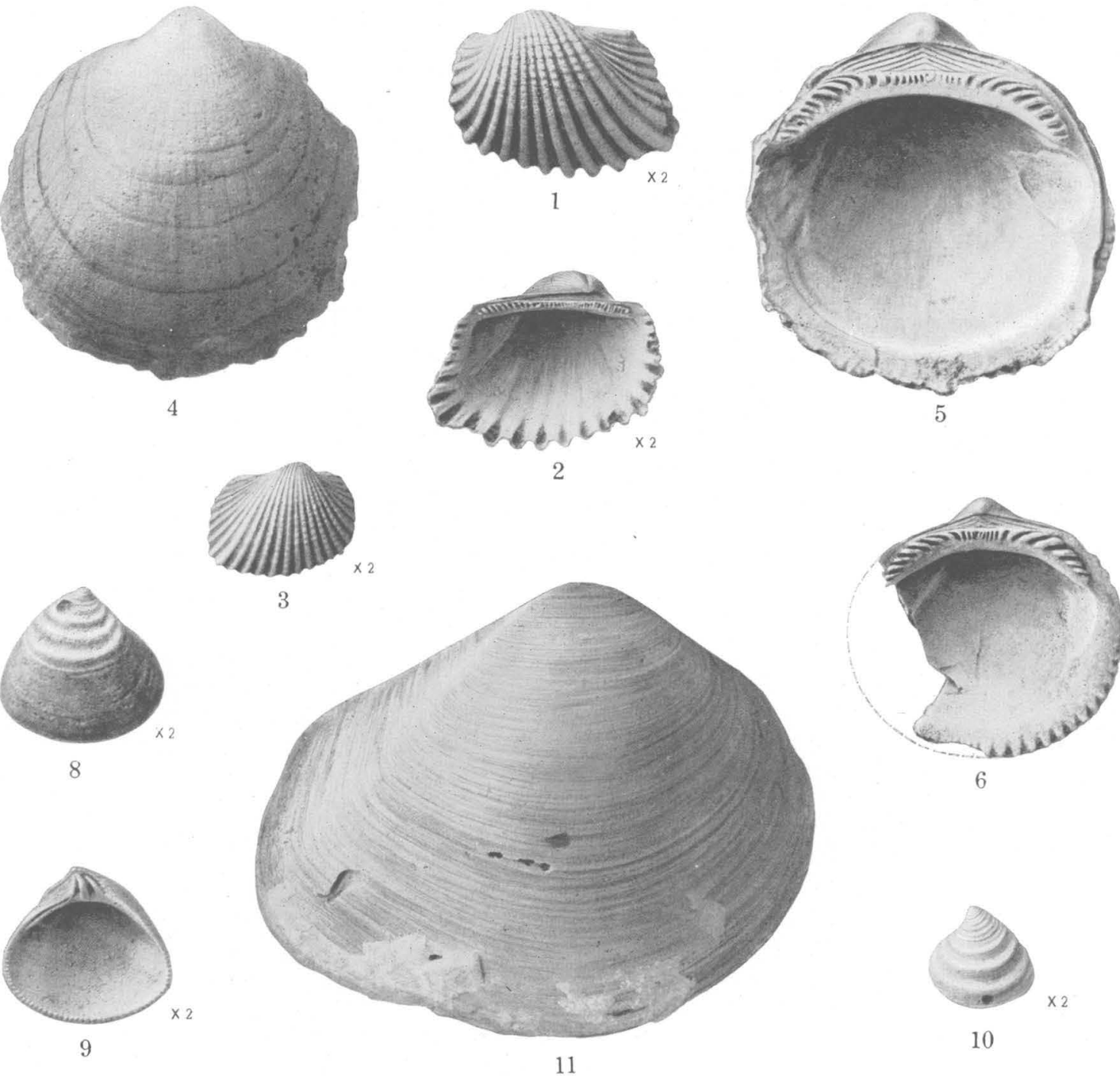

11
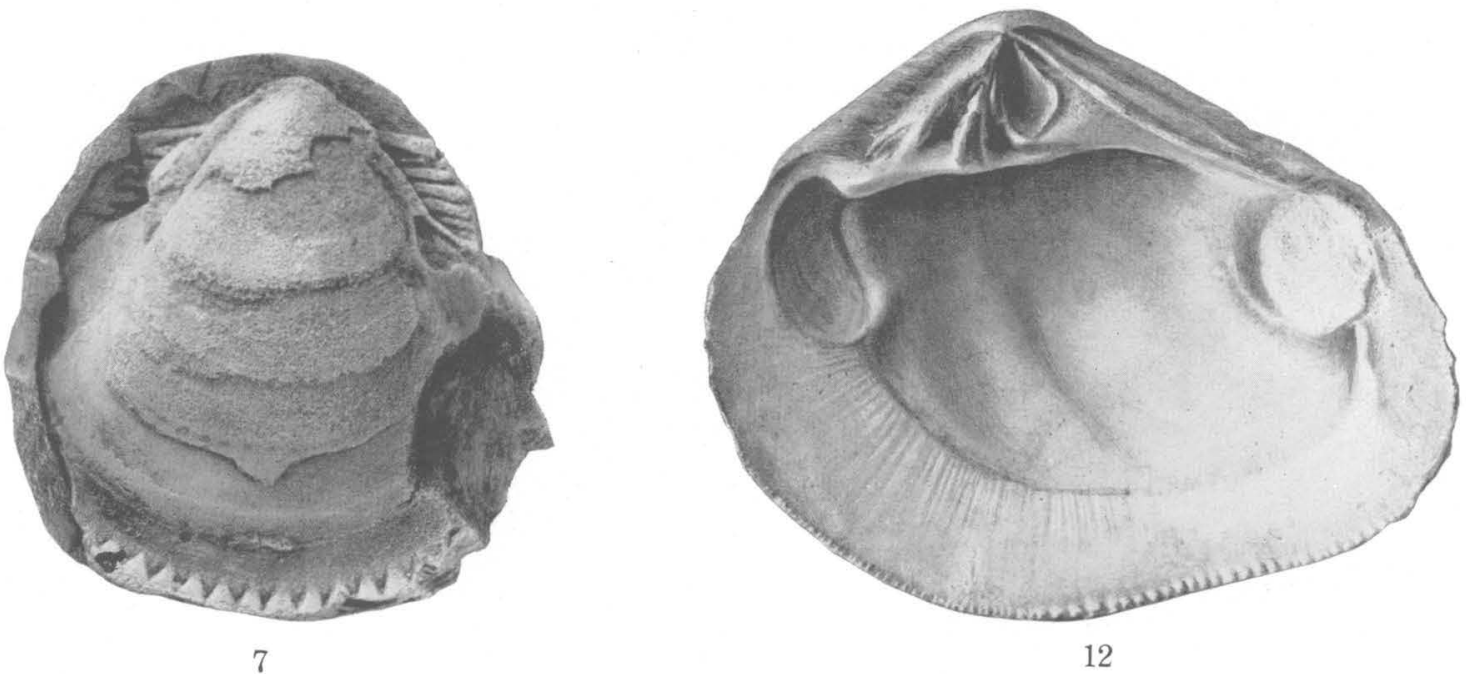

FOSSILS FROM THE TRENT MARL

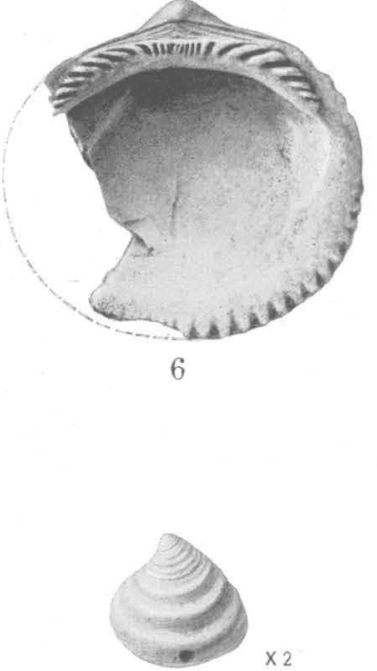

10 


\section{PLATE VIII}

Fraures 1-3. Arca (Scapharca) silverdalensis Kellum, n. sp. (p. 34).

1. The type, a left valve from Silverdale, Onslow County, N. C. U. S. Nat. Mus. catalogue No. 353302.

2. Interior of the type specimen.

3. A right valve from the same locality. U. S. Nat. Mus. catalogue No. 353303.

Figures 4-6. Glycymeris anteparilis Kellum, n. sp. (p. 35).

4. The type, a right valve, from Silverdale, Onslow County, N. C. U. S. Nat. Mus. catalogue No. 353309.

5. Interior of the type specimen.

6. Interior of a smaller specimen from the same locality. U. S. Nat. Mus. catalogue No. 353311.

Figure 7. Glycymeris sp. (p. 35). Internal cast of a specimen from Trent River, $31 / 2$ miles below Polloksville, Jones County, N. C. U. S. Nat. Mus. catalogue No. 353310.

Ficunes 8-10. Astarte onslowensis Kellum, n. sp. (p. 36).

S. The type, a right valve from Silverdale, Onslow County, N. C. U. S. Nat. Mus. catalogue No. 353244.

9. Interior of the type specimen.

10. A left valve from the same locality. U. S. Nat. Mus. catalogue No. 353246.

Fraures 11-12. Crassatellites mississippiensis var. silverdalensis Kellum, n. var. (p. 36). The type, a right valve, from Silverdale, Onslow County, N. C. U. S. Nat. Mus. catalogue No. 353291.

11. Exterior.

12. Interior. 


\section{PLATE IX}

Figures 1-3. Venericardia nodifera Kellum, n. sp. (p. 36). The type, a right valve, from Silverdale, Onslow County, N. C. U. S. 1. Exterior. Nat. Mus. No. 353227.

2. Interior.

3. Dorsal view.

Figures 4-5. Phacoides (Pseudomiltha) nocariensis Kellum, n. sp. (p. 37). The type, a left valve, from Silverdale, Onslow County, N. C. U. S. Nat. Mus. catalogue No. 353249.

4. Exterior.

5. Interior.

Figures 6-7. Cardium sp. (p. 37).

6. An internal cast from Trent River, 12 miles northwest of New Bern, N. C. U. S. Nat. Mus. catalogue No. 353252.

7. Squeeze showing sculpture of a portion of the surface of a specimen from.Trent River, $31 / 2$ miles below Polloksville, Jones County, N. C. U. S. Nat. Mus. catalogue No. 353255.

Figures 8-9. Venus gardnerae Kellum, n. sp. (p. 37). The type, a right valve, from Silverdale, Onslow County, N. C. U.S. Nat. Mus. catalogue No. 353294.

8. Exterior.

9. Interior.

Figures 10-12. Venus erecta Kellum, n. sp. (p. 38).

10. A left valve from Silverdale, Onslow County, N. C. U. S. Nat. Mus. catalogue No. 353296.

11. The type, a right valve, from the same locality. U. S. Nat. Mus. catalogue No. 353295 .

12. Interior of the type.

Figures 13-14. Antigona (Artena) lamellacea Kellum, n. sp. (p. 38). The type, a left valve, from Silverdale, Onslow County, 13. Exterior.

N. C. U. S. Nat. Mus. catalogue No. 353313.

14. Interior.

52 
U, S. GEOLOGICAL SURVEY

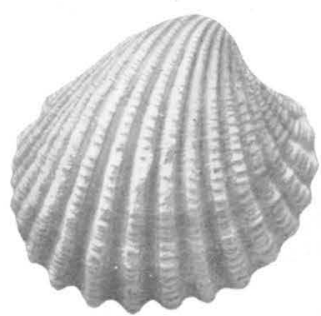

1
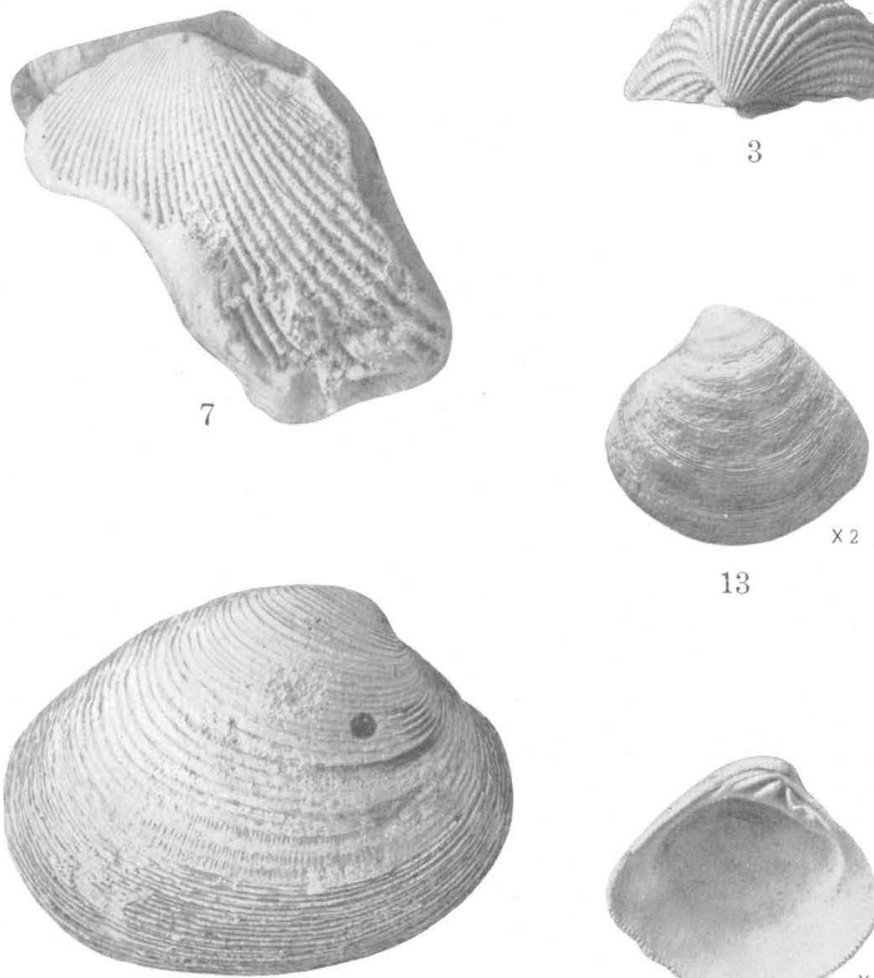

8

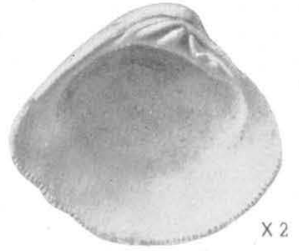

14

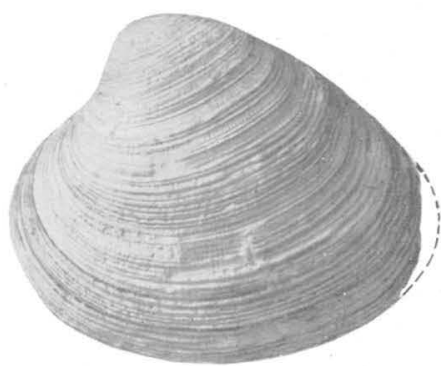

10

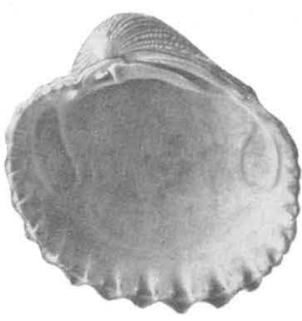

2
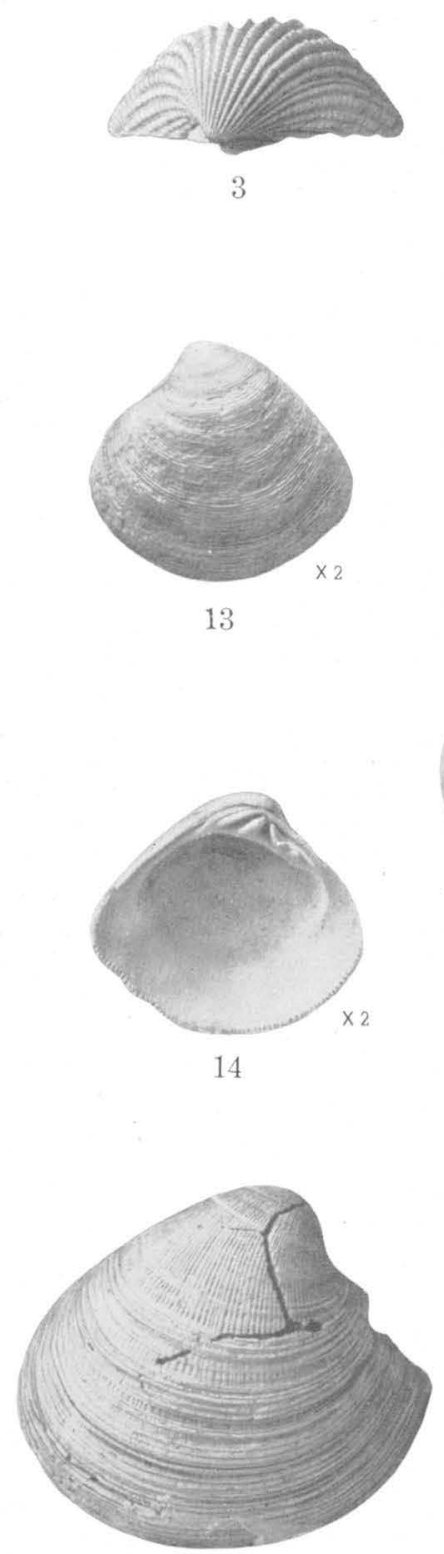

11

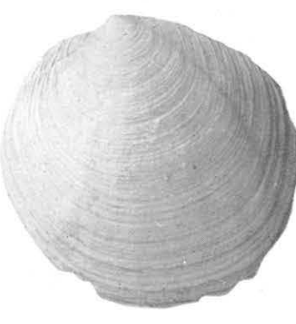

4

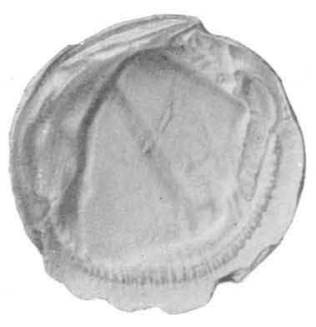

5

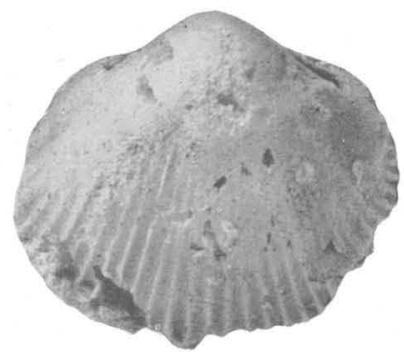

6

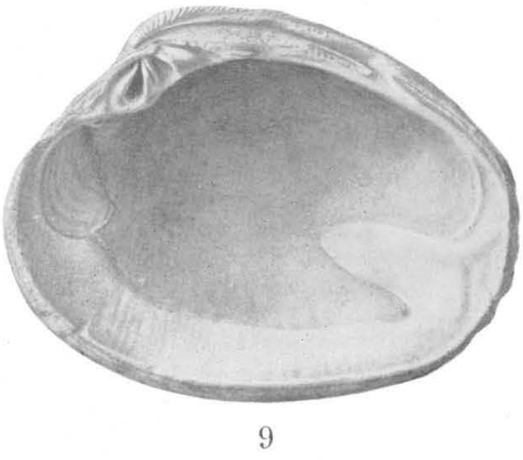

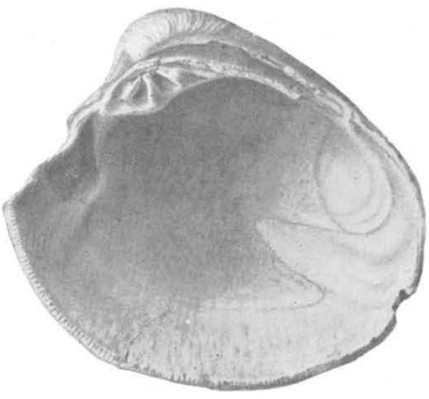

12

FOSSILS FROM THE TRENT MARI 
U. S. GEOLOGICAL SURVEY

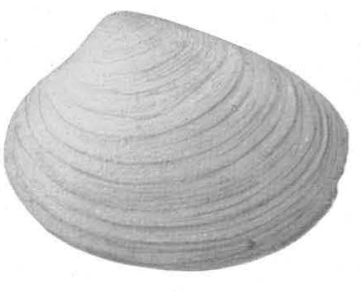

1
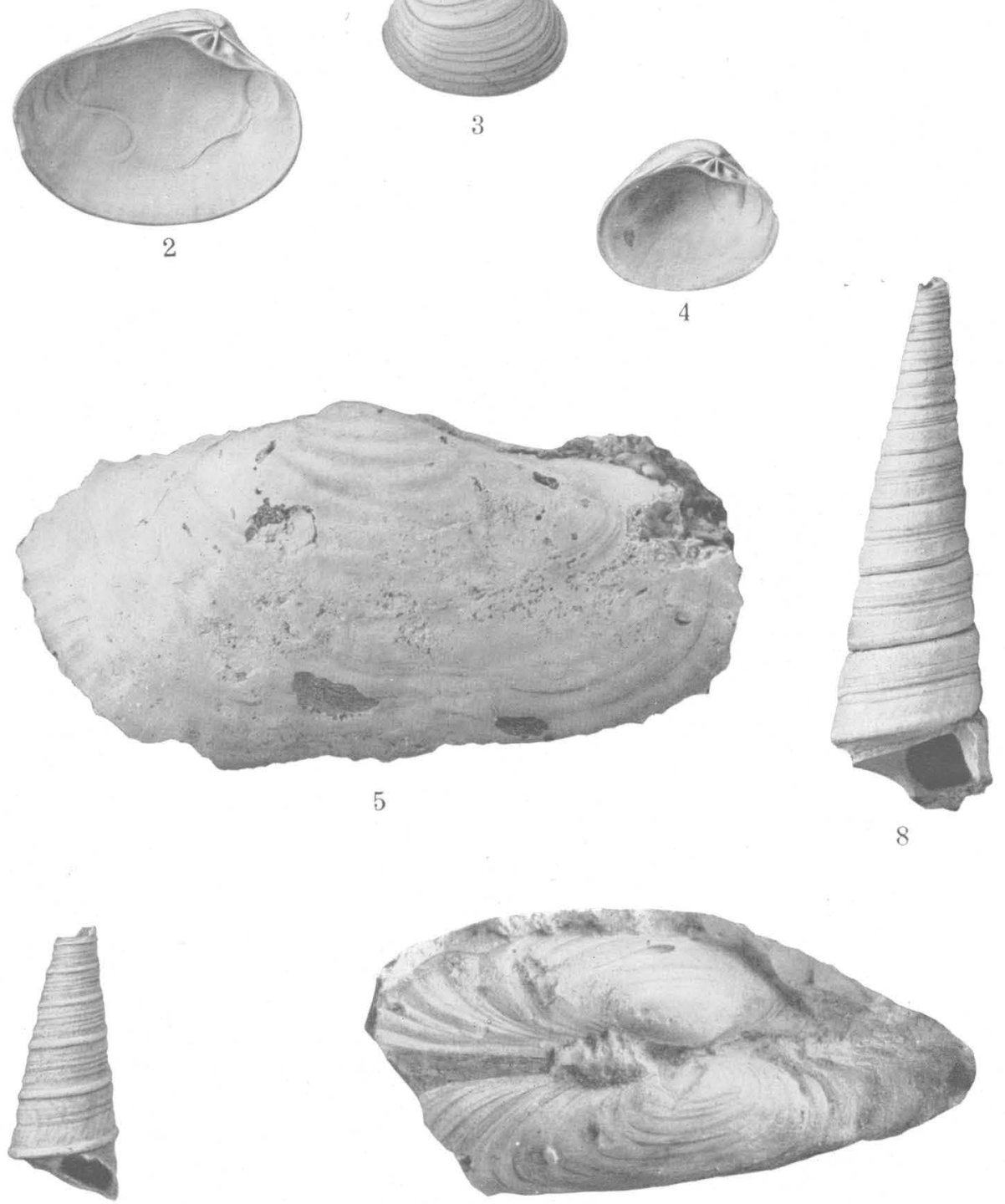

9

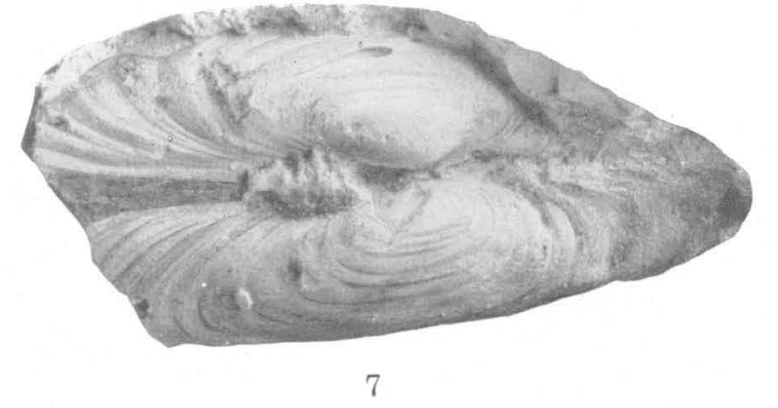

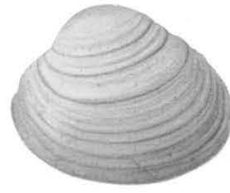

3

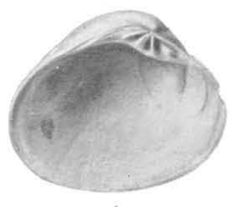

PROFESSIONAL PAPER 143 PLATE X

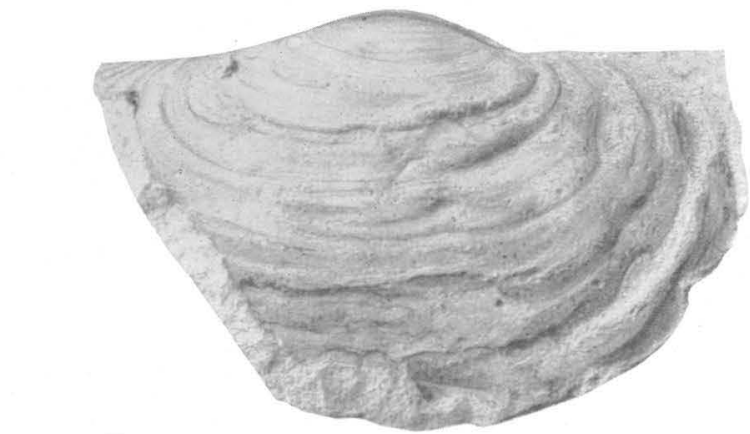

6

FOSSILS FROM THE TRENT MARL 


\section{PLATE $\mathrm{X}$}

Frgunas 1-2. Macrocallista minuscula Kellum, n. sp. (p. 38). The type, a left valve from Silverdale, Onslow County; N. C. 1. Exterior. U. S. Nat. Mus. catalogue No. 353230 .

2. Interior.

liaures 3-4. Macrocallista tia Kellum, n. sp. (p. 39). The type, a left valve, from Silverdale, Onslow County, N. C. U. S. Nat. Mus. catalogue No. 353229 .

3. Exterior.

4. Interior.

Fiauras 5-7. Panope sp. (p. 39).

5. Internal cast of a left valve from Trent River, $31 / 2$ miles below Polloksville, Jones County, N. C. U. S. Nat. Mus. catalogue No. 353306.

6. Plaster cast showing the sculpture and form of a right valve from the same locality. U. S. Nat. Mus. catalogue No. 353305 . 7. Dorsal view of the cast shown in Figure 6, showing sculpture and form of right and left valves.

Ficures 8-9. T'urrilella fuerta Kellum, n. sp: (p. 4.0).

8. The type, from Silverdale, Onslow' County, N. C. U. S. Nat. Mus. catalogue No. 353242.

9. A specimen from the same locality, showing individual variation of sculpture. U: S. Nat. Mus. catalogue No. 353239. 


\section{PLATE XI}

Figures 1-3. Busycon spiniger var. onslowensis Kellum, n. var. (p. 40). Views of the type, from Silverdale, Onslow County, N. C. U. S. Nat. Mus. catalogue No. 353254.

Figures 4-5. Lyria carolinensis Kellum, n. sp. (p..40). Views of the type, from Silverdale, Onslow County, N. C. U. S. Nat. Mus. catalogue No. 353253.

Figures 6-7. Scaphella stromboidella Kellum, n. sp. (p. 41).

6. The type, from Silverdale, Onslow County, N. C. U. S. Nat. Mus. 'catalogue No. 353307.

7. Another specimen from the same locality. U. S. Nat. Mus. catalogue No. 353308.

Figures 8-10. Conus postalveatus Kellum, n. sp. (p. 41).

8. The type from Silverdale, Onslow County, N. C. U. S. Nat. Mus. catalogue No. 353273.

9. Another specimen from the same locality. U. S. Nat. Mus. catalogue -No. 353270.

10. Top view of the type specimen. 
U. S. GEOLOGICAL SURVEY
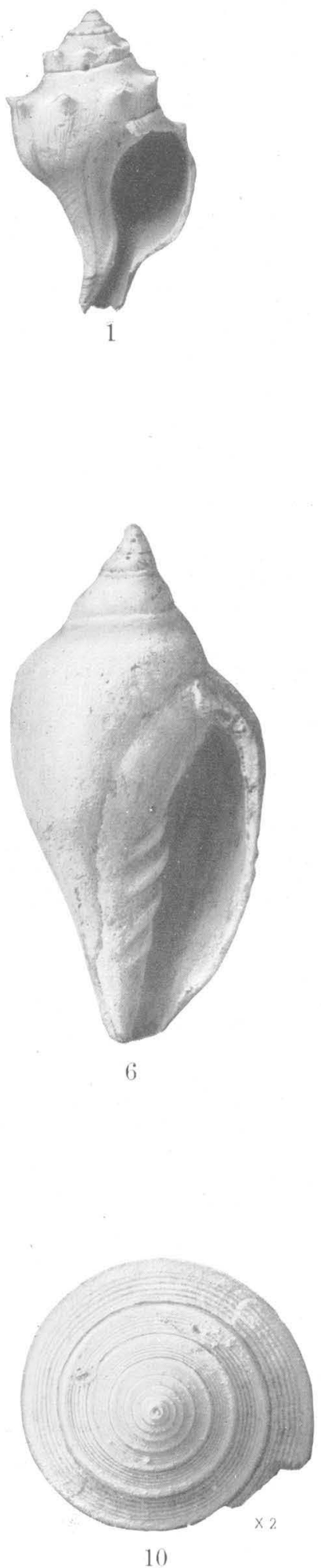
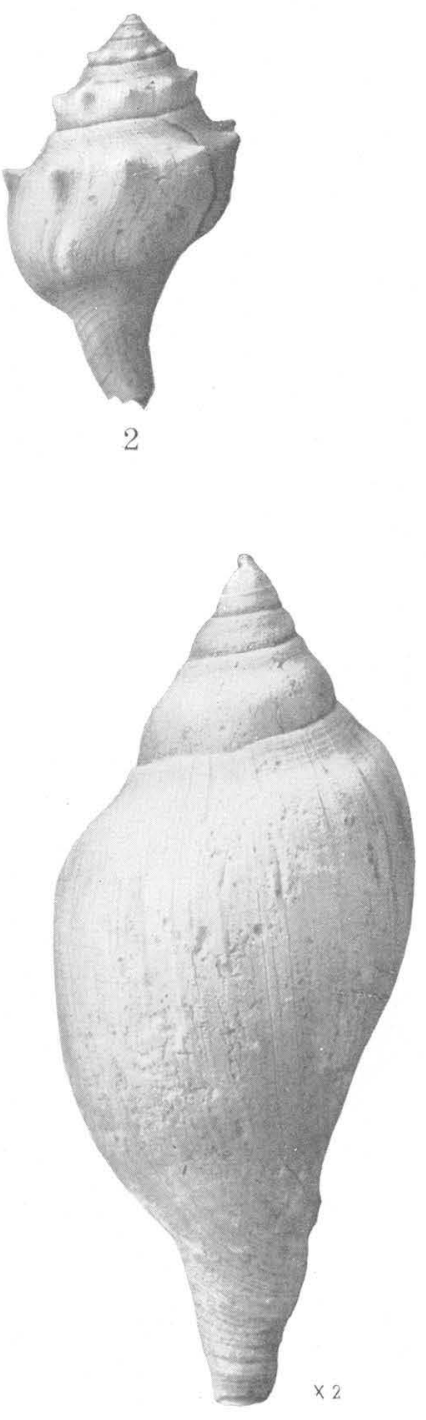

7

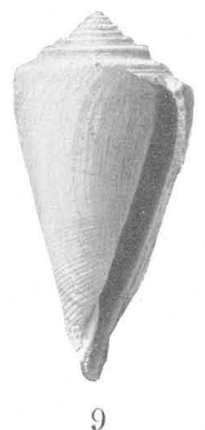

PROFESSIONAL PAPER 143 PLATE XI

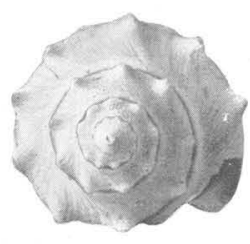

3
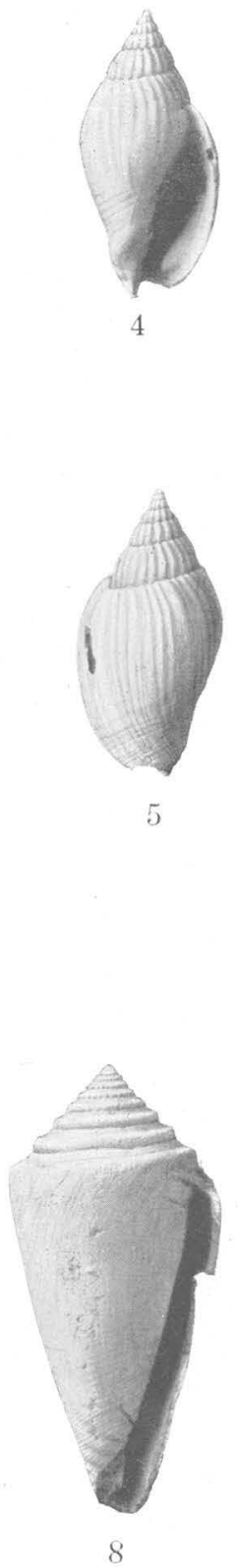

FOSSILS FROM THE TRENT MARL 


\section{INDEX}

$\Lambda$

A cknowledgments for aid

Aldrich, T. H.; cited.

Anomia simplex D'Orbigny. sp......

Anomiidue.

Anthozon, representation of, in the Castle Hayne fauna.

Antigonn (Artena) lamelhcen Kellum, n. sp. shopardi Dall

A ren cancellata 'Tuomey

carolinensis Wagner

lesueuri Doll.

milliflln Dall.

reticulutu Comelin

rhomboidella Len.

stuminata Dall.

(Scapharca) silverdalensis Kellum, n. sp.................... 34-35, Pl. vII

sp. $a . . . . . . . . . . .16$, Pl. I

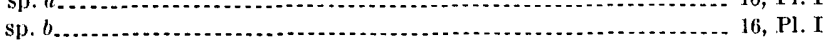

sp. c................ 16-17, PI. I

Arcidue.

$16-17,34-35$

Asturte onslowensis Kellum, n. sp................................... 36. PII

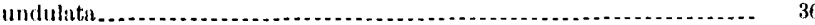

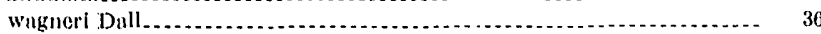

Asturtidao.

$\Lambda$ turia alabnmensis (Morton) vanuxemi Conrad

\section{$\mathrm{B}$}

Borry, E. W., acknowledgment to..

Brachiopoda.

representution of, in the Castle Hayne faum

Brown, A. P., and Pilsbry, 1I. A., ciled.

Buccinidae.

Buccinum porcinum Suy

usycon spiniger var. onslowensis Kellum, n. var.................. 40, Pl. XI spiniger var. spiniger (Conrad)

\section{C}

$\circ$

Calliostoma sp.

Calyptrnen trochiformis Lamarck... sp.

26 , Pl. IV

27,39

Calyptraeidnc..................... 27,39

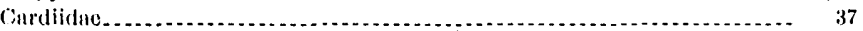

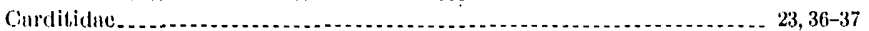

Gardium sp..............

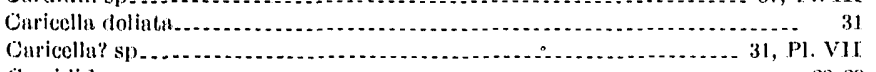

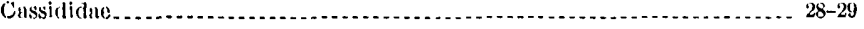

Cossidulidno

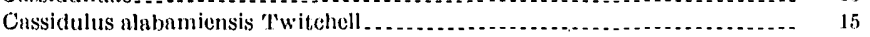

(Pygorhynchus) berryi Kellum, n. sp........ I cturolinensis 'I'witchell

carolinensis var. cravenensis Kellum, n. var. ................ 15, P1. I

(Rhynchopygus) raveneli Twitchell................................. 15

Cussis? sp.

Castle Hanyo fauna, biologic analysis of .....................................

Castlo liayno marl, ficld stations of ..................................... 9-10 occurrence of species in ............................... 11

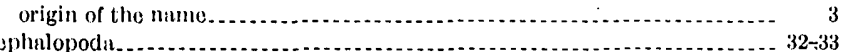

representation of, in the Castle Hayne fauma

Chuma sp. a......................................................... 231

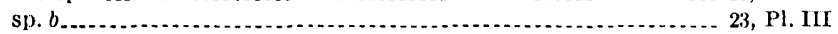

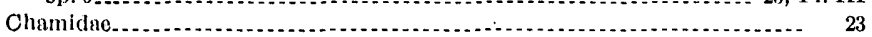

Cidaridnc...............

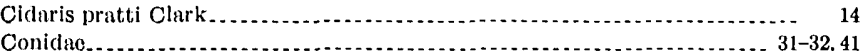

Conrud, T. A., cited......................................... 17, 18, 19, 21, 22, 24, 27,33, 36

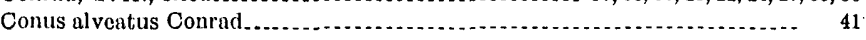
gyratus Morton ....................

mutilatus 'Tuomey?........................................... 31-32, PI. VII

postalveatus Kellum, n. sp................................... 41, Pl. XI

sauridens Conrad.....
32

Cooke, C. W ythe, acknowledgment to.

Correlation of the Custlo Hayne marl.

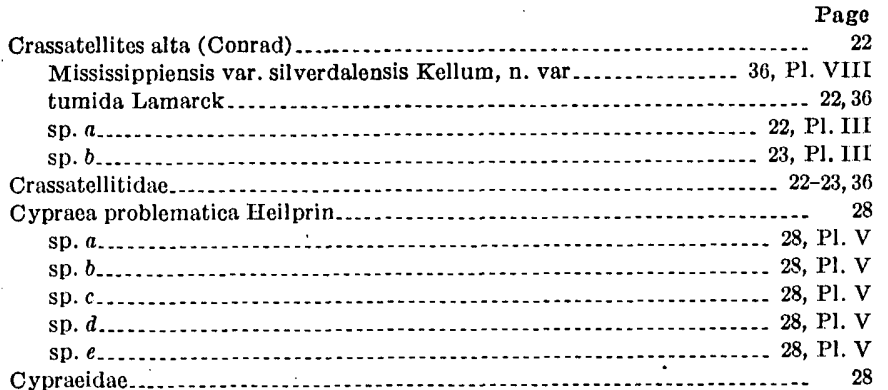

D

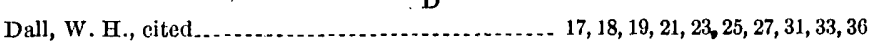

$\mathbf{E}$

Echinocyamus parvus Emmons.

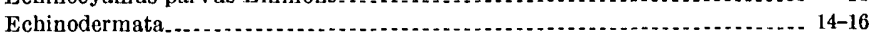

Echinoidea, representation of, in the Castle Hayne fauna............... 6

Echinolampas appendiculatus Emmons................................ 15

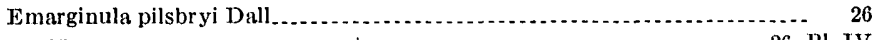
sp. $a \ldots \ldots \ldots$
sp. $b \ldots \ldots \ldots \ldots$ Emmons, Ebenezer, work of, on the Tertiary coastal deposits of North

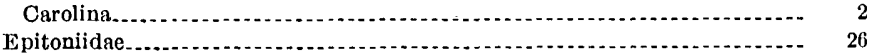

Epitonium aequabile Kellum, n. sp..... V

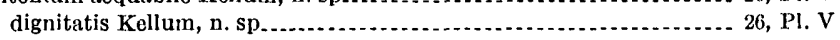

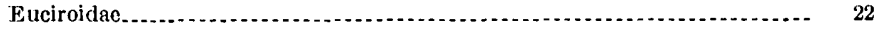

Eupatagus carolinensis Clark......................................... 16

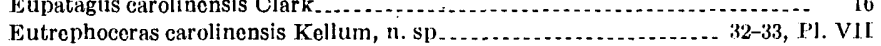
$\begin{array}{lr}\text { dekayi................. } & 32 \\ \text { perlatus Morton } & \end{array}$ perlatus Morton....................

Fasciolaridae

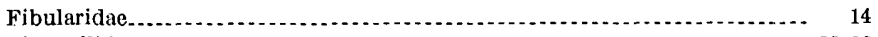

Fissurellidae..............

$\begin{array}{ll}\text { Fissuridea marlboroensis Clark } \ldots \ldots \ldots \ldots \ldots & 25 \\ \text { mauri Aldrich } & 25\end{array}$ mauri Aldrich............. penderenis Ke III

Fusinus abruptus (Tuomey)? sp .

(

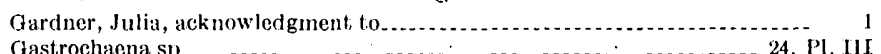

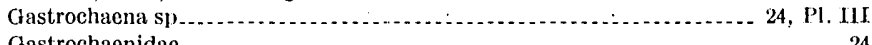
Gastrochaenidae representation of, in the Castle Jayne fauna...

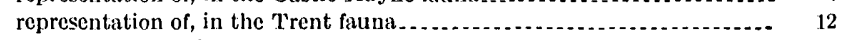
Glycymeris anteparilis Kellum, n. sp........................... 35, Pl. vilt parilis Conrad .......
sp. ?. 35 sp. ?:........... PIII

Harris, G. D., cited ................................................ 20, $22,24,35$ Pectens from the Trent marl described by $\ldots \ldots \ldots \ldots$ Hemipatagus subrostratus Clark...........

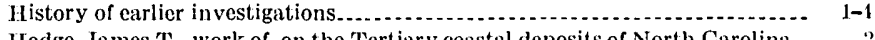
Hodge, James T., work of, on the Tertiary coastal deposits of North Carolina.-

Isocardiidae.

I

K

Kerr, W. C., work of, on the Tertiary coastal deposits of North Carolina.... 2

I

Lamarck, J. B. de, cited .......................................... 39

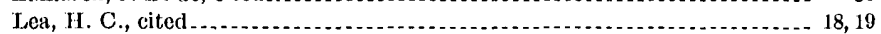

Leptomaria gigantea Whitfield........ 25

Linthia hanoverensis Kellum, n. sp. wilmingtonensis Clark ..........

Lucina mutabilis Lamarck
sp: 
Lucinidae........... Page Lyell, Charles, cited work of, on the Tertiary coastal deposits of North Carolina.

Lyria carolinensis Kellum, $\mathrm{n}$. sp heilprini.

M

Macrocallista acuminata Dall sp ............ $38-39$, Pl. $\mathrm{X}$

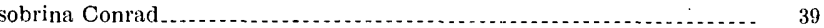
tia Kellum, n. sp

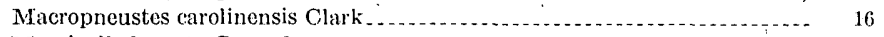

Marginella larvata Conrad

$\mathrm{sp}$.

Margịnellidae

Meiocardia agassizi Dall carolinae Tharris

Miller, B. L, work of, on the Tertiary coastal deposits of North Carolina Mitchell, Elisha, work of, on the Tertiary coastal deposits of North Carolina Mitra, sp. $a-f$

Morton, S. G., cited 30-31, Pl. V

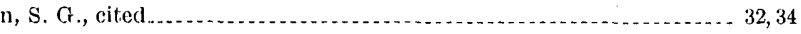

\section{$\mathrm{N}$}

Naticidae

\section{0}

Oliva posti Dall

Olividae.

Ostrea alabamiensis subsp. georgiana Conma

compressirostra.

divaricatal Lea

falco Dall ?..

mortoni Cabb

pererassa Conrad

rugifera Dall

sellacformis Conrad

subtrigonalis Evans and Shumard

trigonalis Comrad.

vicksburgensis Comrad

virginiana.

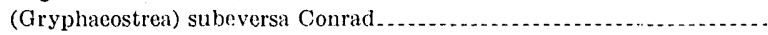
Ostreidae.

\section{$\mathrm{P}$}

Panope whitfieldi Dall sp.

Pecchiolia dalliana Harris

vemmelensis Vincent

22

n. sp ..................................... 20, P1I carolinensis Conrad.

claibornensis Conrad

cookei Kellum, n. sp...

cushmani Kellum, n. Sp

elixatus Conrad?

poulsoni...

suwaneensis Dal

trentensis Harris

wahtubbeanus

(Chlamys) deshayesii Le

membranosus Mortion

(Pseudamusium) scintillatus Comrar

Pectinidae.

Pelecypoda

representation of, in the Castle Hayne fauna......................... 6 -7

representation of, in the Trent fauna

periarchus lyelli (Conrad) ...

Phacoides (Miltha) pandatus (Conrad)

(Pseudomiltha) nocariensis Kellum, n. sp.................... 37, Pi. IX

Phalium globosum Dall sp...

Pholadomya claibornensis Aldrich.

marylandica Conrar

Pholadomyidae.

Pilsbry, H. A., with Brown, A. P., cited

Pitaria securiformis (Conrad)?

Plejona conoides (Tuomey) ?.

sayana (Conrad) ..

cf. $P$. petrosus (Conrad)
33

2

I

1

Pleur

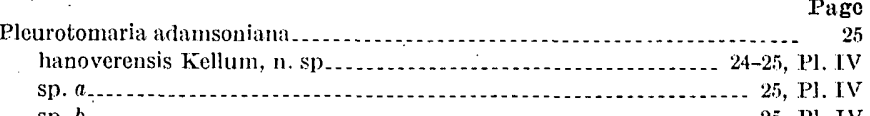

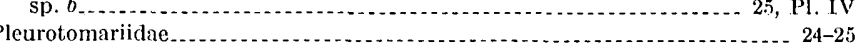

Plicatula densata Conrad

filamentosa Conrad .............................................. 21

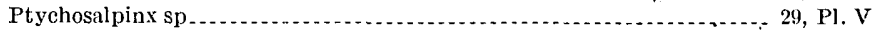

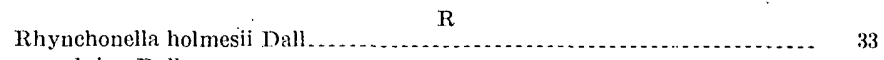

salpinx Dall ........................................................ 33

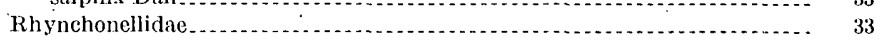

Saxicavidae...

$\begin{array}{ll}\text { Say, Thomas, cited } \ldots \ldots \ldots & 37 \\ \text { Scala ranellina Dall } \ldots \ldots \ldots & \ldots\end{array}$

Scala ranellina Dall $\ldots \ldots \ldots$
sp $\ldots \ldots \ldots \ldots$

Scaphella stromboidella Kellum, n. sp.................................. 41, Pl

(Encymba) ocalana Dall?................... 31

Scope of the investigation . . .

Scutellidae........... 15

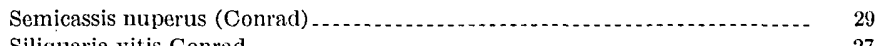

Siliquaria vitis Conrad. . .

Sinum imperforatum Dall ................................................. 40

Spatangidae...........

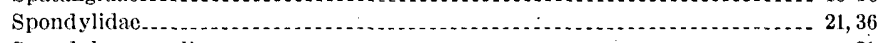

Spondylus gregalis . . . . . .

lamellacea Kellum, n. sp . . . . . . II

Stratigraphic relations of the marls. .............

Strombidae..............

Strombus sp? T
$\quad$ crassa Kellum, n. sp..............

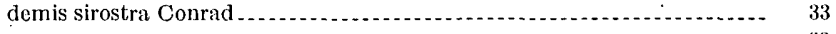

uva _. .

wilmingtonensis Lyell and Sowerby

T'erebratulidae . . . . . . . . . . .

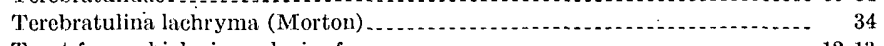

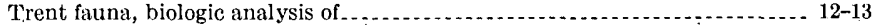

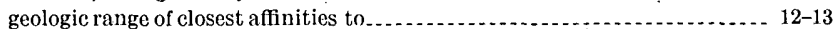

Trent marl, field stations of . . . . .

Joccurrence of species in ..........

origin of the name................................................... 3

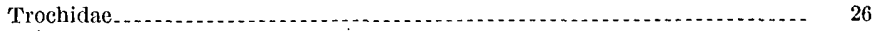

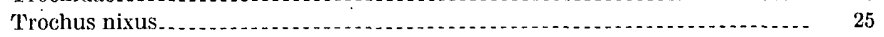

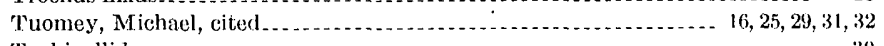

Turbinellidae.................... 30

Turritella carinata Lea $\ldots \ldots \ldots \ldots \ldots \ldots . . .27$

fuerta Kellum, n. sp .................................... 40, Pl. X

$\begin{array}{lll}\text { indenta Conrad } \ldots & 40 \\ \text { (tampae var, ?) medioconstricta Dall } \ldots \ldots \ldots \ldots \ldots . . . & 40\end{array}$

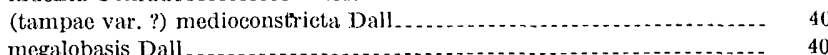

subtilis Kellum, n. sp...................

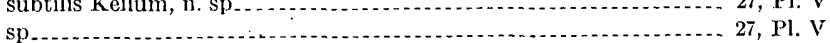

sp
Turritellidae $\ldots \ldots \ldots \ldots$

$\begin{array}{cc}V & \\ \text { Vasum haitense } \ldots \ldots \ldots & \end{array}$

wilmingtonense Brown and Pilsbry ................................. 30

Venericardia hadra Dall $\ldots$

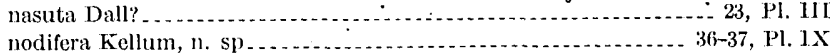
serricosta Heilprin $\ldots$ sp (Cyclocardia) granulata Say

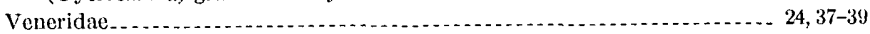

Vermiculariidac

Venus erecta Kellum, n, sp.....

gardnerae Kellum, n. sp ..................................

halidona Dall . . . .

plena Conrad ...

Volutidae... $\mathrm{x}$

Xenophora conchyliophora (Born) $\ldots$

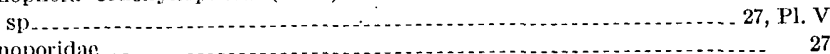

